Fernando Janczur Velloso

Expressão de isoformas da proteína do retardo mental

do X frágil (FMRP) e sua regulacão

SÃO PAULO

2008 
Fernando Janczur Velloso

\section{Expressão de isoformas da proteína do retardo mental do X frágil (FMRP) e sua regulação}

Dissertação apresentada ao Instituto de Biociências da Universidade de São Paulo para obtenção de título de Mestre em ciências na área de Biologia/Genética

ORIENTADORA: PROF. DRA. LUCIANA AMARAL HADDAD

SÃO PAULO

2008 
Aos meus pais, Alcir e Christine 


\section{AGRADECIMENTOS}

À minha família pelo apoio e confiança

À minha orientadora pelo amadurecimento científico

Às Profas. Angela Vianna Morgante e Regina Célia Mingroni Netto pelo apoio e uso das instalações de seus laboratórios

À Profa. Silvana Chiavegatto pela colaboração no desenvolvimento e análise dos experimentos de PCR em tempo real

Á todos os amigos e colegas de bancada pelos momentos científicos e lúdicos, sem os quais este trabalho não seria possível

À FAPESP pelo auxílio financeiro

Ao CNPq pela bolsa de mestrado 


\section{ÍNDICE GERAL}

RESUMO

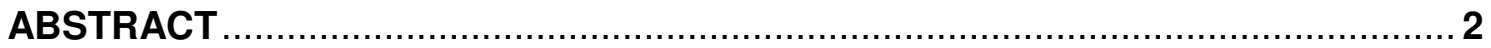

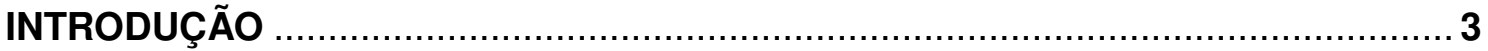

I. Splicing: 'corte e emenda' do transcrito primário de RNA …................................... 5

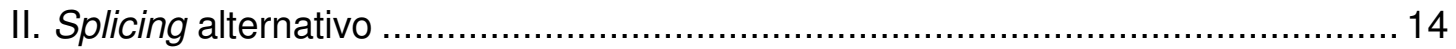

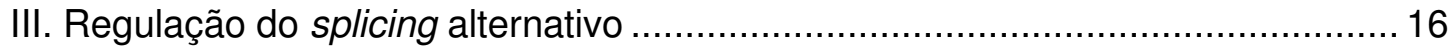

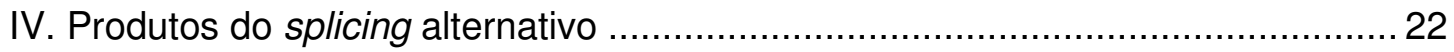

V. Splicing alternativo e diversidade funcional no SNC.......................................... 23

VI. Splicing alternativo do gene do Retardo Mental do X Frágil (FMR1) .................. 25

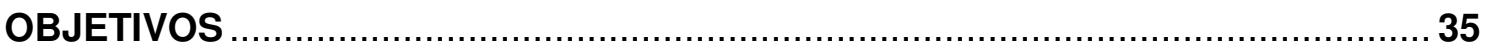

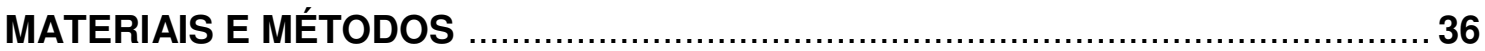

I. Análise por RT-PCR em tempo real dos padrões de expressão das isoformas de Fmr1 36

I.I Animais e obtenção de tecidos ......................................................... 36

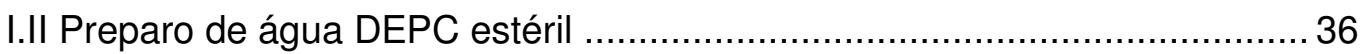

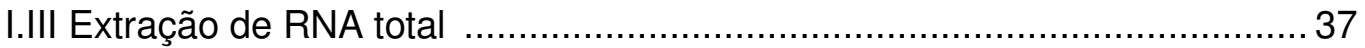

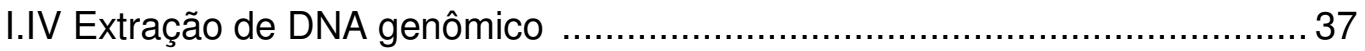

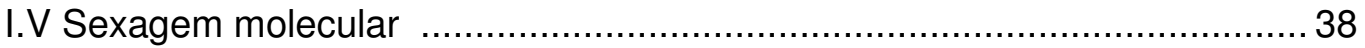

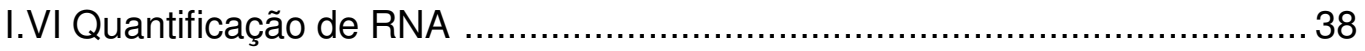

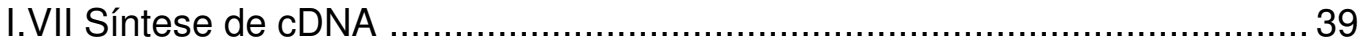

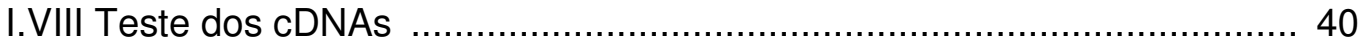

I.IX Reação de PCR em tempo real ........................................................ 40

II. Análises in silico para busca de elementos regulatórios ................................... 43

III. Clonagem de segmento genômico do Fmr1: Produção de um mini-gene ........... 44

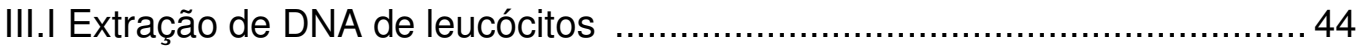

III.II Amplificação do segmento genômico do éxon 11 ao éxon 12 do Fmr1 .... 44

III.III Purificação do produto de PCR ........................................................ 45

III.IV Adição de Adenosina terminal .......................................................... 46

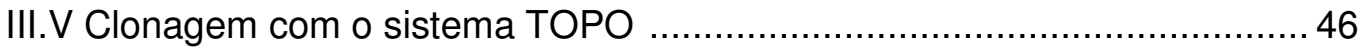

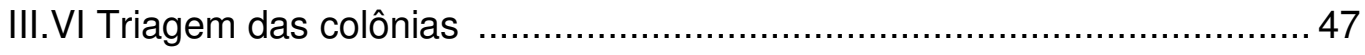

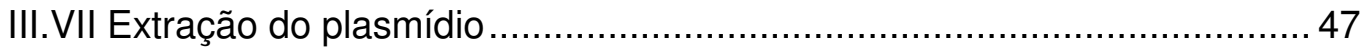

III.VIII Quantificação do plasmídio .................................................... 48 
III.IX Digestão do plasmídio para averiguar inserto ..................................... 49

III.X Purificação do inserto para subclonagem.................................................49

III.XI Digestão e desfosforilação do vetor de clonagem pcDNA3 …................. 49

III.XII Quantificação de vetor e inserto .................................................. 50

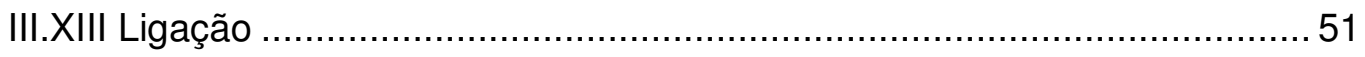

III.XIV Preparo de células competentes pelo $\mathrm{CaCl} 2$....................................51

III.XV Transformação bacteriana por choque térmico ...................................52

III.XVI Triagem das colônias contendo o vetor pcDNA3 …............................ 52

III.XVII Seqüenciamento do plasmídio ................................................. 52

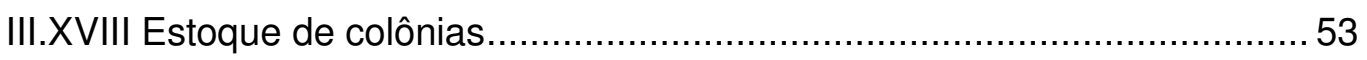

III.XIX Extração de plasmídios............................................................. 54

III.XX Produção das construções contendo deleções .................................... 54

Clone gFX11X13

III.XXI Clonagem das construções contendo deleções ..................................56

III.XXII Transfecção em células de rato .....................................................56

III.XXIII Análise da expressão das construções ........................................ 57

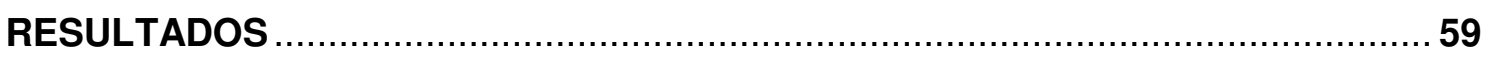

I. Estudo do padrão de expressão do éxon 12 de Fmr1 ...................................59

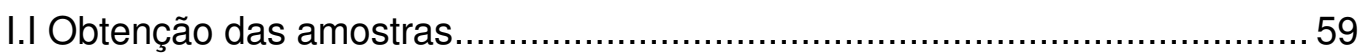

I.II. Estudo da expressão por PCR em tempo real ........................................ 63

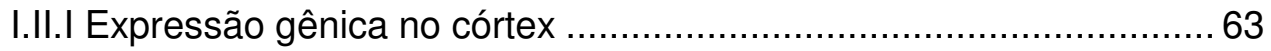

I.II.II Expressão gênica no hipocampo ......................................... 64

I.II.III Expressão gênica no cerebelo.............................................. 66

I.II.IV Avaliação geral do estudo da expressão do éxon 12 do Fmr1 ......6 67

II. Análises in silico das seqüências genômicas do Fmr1 …............................... 69

II.I Busca por ESE e ESI no éxon 12 …............................................. 70

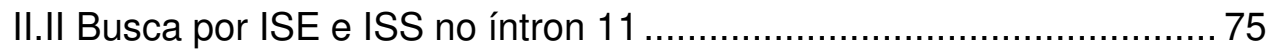

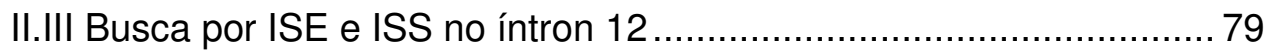


III. Estudo da expressão do mini-gene do éxon 12 do Fmr1 .................................. 83

III.I Obtenção do clone de Fmr1 tipo selvagem ................................. 83

III.II Expressão do clone gFX11X13 em células C6: Análise dos produtos

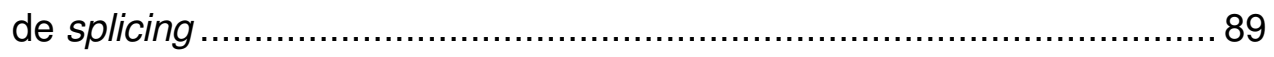

III.III Deleções do clone gFX11X13 _................................................. 93

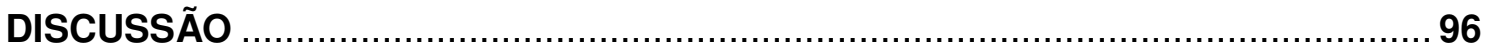

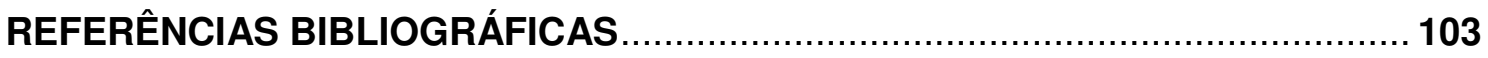




\section{ÍNDICE DE FIGURAS}

Figura 1: Etapas do processamento do transcrito primário de RNA ........................... 4

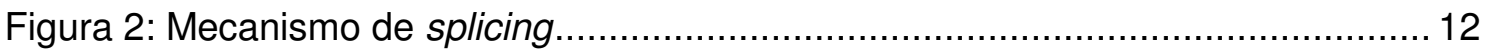

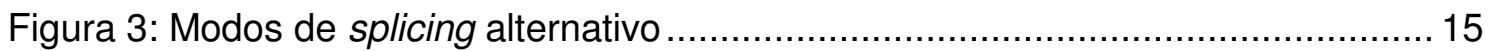

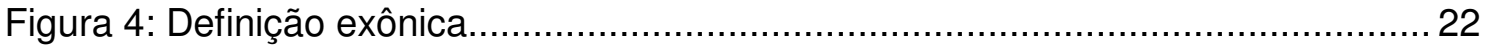

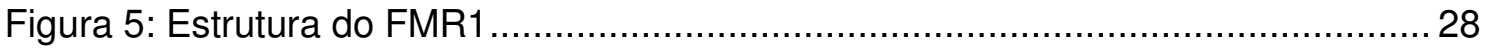

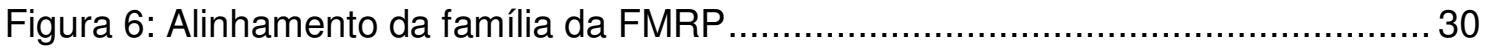

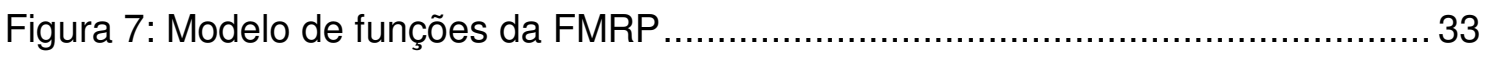

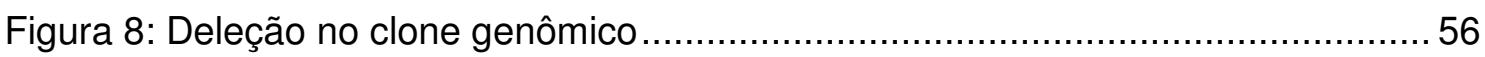

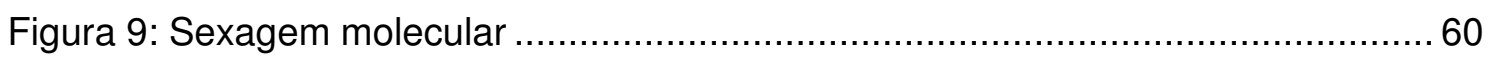

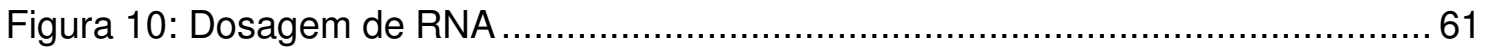

Figura 11: Teste dos cDNAs e oligonucleotídeos para tempo real .............................62

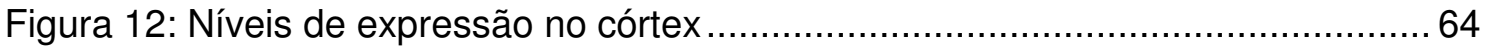

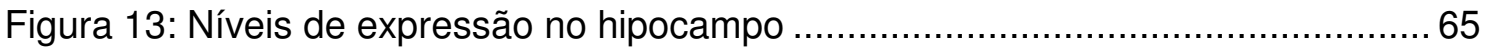

Figura 14: Níveis de expressão da ciclofilina .................................................. 66

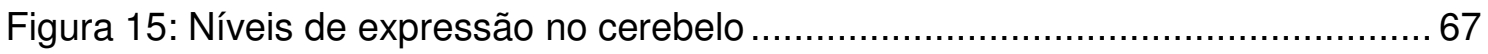

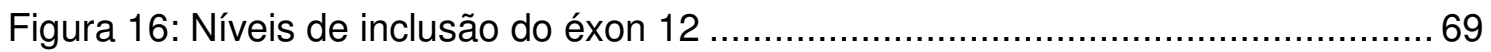

Figura 17: Resultado in silico no éxon 12 humano (Acescan2) ................................ 71

Figura 18: Resultado in silico no éxon 12 humano $(A S D)$....................................... 71

Figura 19: Resultado in silico no éxon 12 humano (ESE Finder) .............................. 73

Figura 20: Resultado in silico no éxon 12 humano (ESR Search) ............................ 74

Figura 21: Resultado in silico no éxon 12 murino (Acescan2) .................................. 75

Figura 22: Resultado in silico no íntron 11 humano (Acescan2) ............................... 76

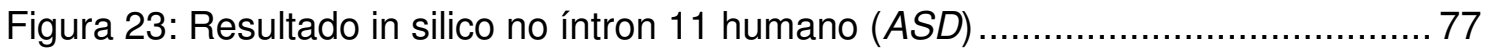

Figura 24: Resultado in silico no íntron 11 murino (Acescan2) ............................... 78

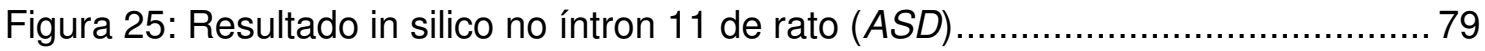

Figura 26: Resultado in silico no íntron 12 humano (Acescan2) ................................ 80 
Figura 27: Resultado in silico no íntron 12 humano $(A S D)$

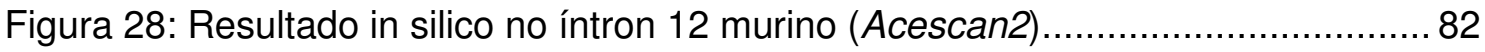

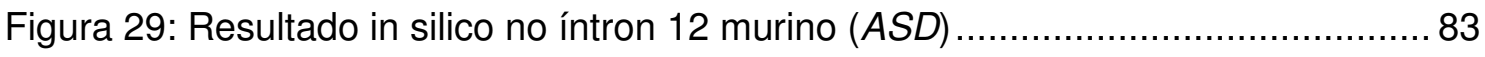

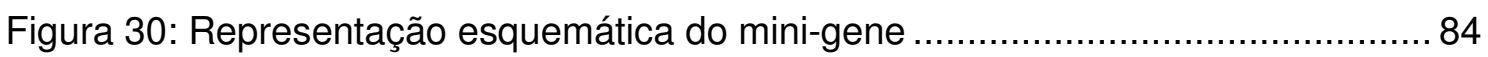

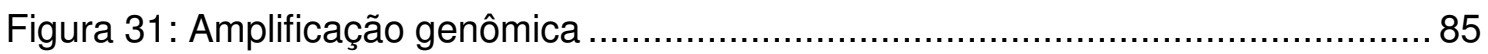

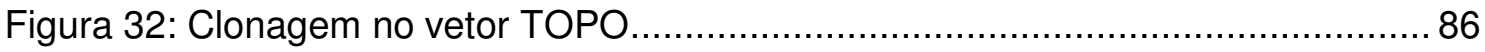

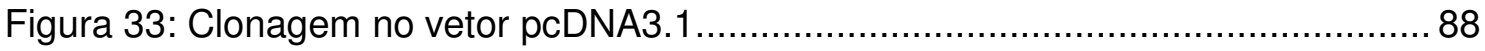

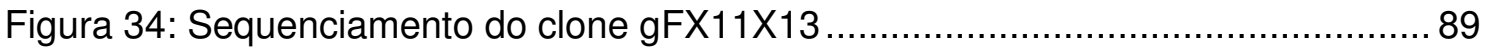

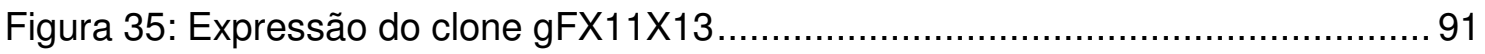

Figura 36: Expressão superexpressa e endógena do clone gFX11X13 .................... 92

Figura 37: Clonagem de gFX11X13

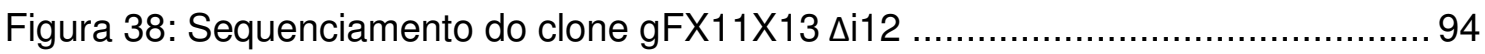

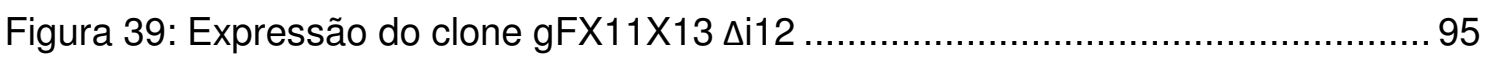




\section{ÍNDICE DE TABELAS}

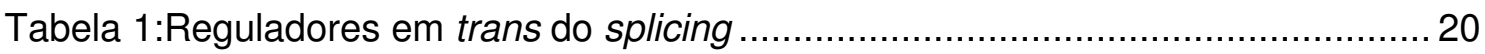

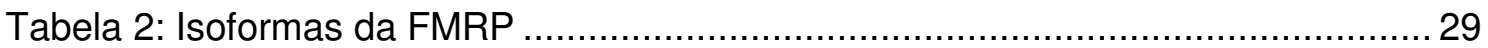

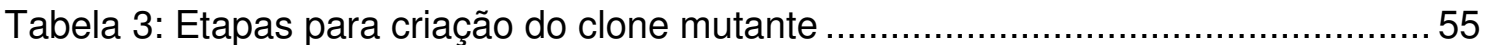




\section{RESUMO}

Entre as modificações sofridas pelo transcrito primário de RNA de eucariontes, o splicing é reponsável pela colocação lado a lado das sequências expressas alinhando a região codificadora no RNAm. Este mecanismo, descrito na década de 1970, como o responsável pela remoção dos íntrons e junção dos éxons consecutivos, é efetuado por um complexo ribonucleoprotéico conhecido como spliceossomo. $\mathrm{O}$ reconhecimento por este complexo dos segmentos definidos como éxons e íntrons depende de diversas sequências presentes no RNA e reconhecidas por ligantes protéicos. A modulação desta interação resulta na geração de diferentes transcritos maduros a partir de um mesmo gene, evento conhecido como splicing alternativo, comum a maioria dos genes humanos e um dos grandes responsáveis pela geração de variabilidade proteômica dos eucariotos e sua complexidade morfo-fisiológica. O splicing alternativo é um importante gerador de diversidade funcional no sistema nervoso central, onde participa da geração de variantes para mais de $80 \%$ dos genes. Entre estes está o gene do Retardo Mental do X Frágil (FMR1), cujo transcrito primário pode sofrer splicing alternativo de quatro éxons, produzindo até vinte isoformas diferentes da FMRP. Os objetivos gerais deste projeto foram (i) a análise da expressão do éxon 12 do Fmr1 em córtex cerebral frontal, hipocampo e cerebelo de ratos em E19 e P2; e (ii) a busca por elementos em cis reguladores do splicing do éxon 12 do Fmr1 de rato.

Para averiguar os níveis da expressão do éxon 12 do Fmr1, no final do período embrionário e início do pós-natal de rato, foi realizada RT-PCR em tempo real com os tecidos citados acima, em E19 e P2. Observamos significativa inclusão do éxon 12 nos transcritos do Fmr1 no córtex frontal em P2 quando comparado a E19, o que não se relacionou ao aumento geral da expressão do Fmr1. No hipocampo, houve aumento da expressão do conjunto de mensagens do Fmr1 e tendência à exclusão do éxon 12 em P2, quando comparado a E19. Estes dados revelam o córtex cerebral como fonte de proteínas ativadoras do splicing do éxon 12 do Fmr1 e onde se deve buscar pela relevância funcional das isoformas da FMRP expressando este éxon.

A busca por elementos reguladores do splicing do éxon 12 se baseiou na avaliação da expressão por RT-PCR de mini-gene de segmento genômico do gene Fmr1 usado para transfectar células C6 (glioma de rato). Estas células demonstraram inclusão preferencial do éxon 12 em seus transcritos superexpressos. Um segundo clone foi gerado com uma deleção a partir do clone original, na região 5' do íntron 12, na qual observamos in silico, elementos ricos em U e C, candidatos a acentuadores da inclusão do éxon 12. A superexpressão deste clone em C6 revelou exclusão preferencial do éxon 12, um padrão invertido em relação ao anteriormente observado. Estes dados indicam o elemento rico em U e C como um forte candidato a acentuar a inclusão do éxon 12 no RNAm do Fmr1.

N. A., Nota do autor: Devido a facilidade do uso "splicing" foi mantido no original em inglês. 


\section{ABSTRACT}

Splicing is an important hnRNA processing mechanism in eukaryotes, aligning exons in the mRNA. First described in the 1970's, it is performed by a molecular complex named spliceosome, which recognizes RNA sequences in the boundaries between exons and introns. Interaction modulation in the spliceosome results in mature transcripts with varying sizes, a process known as alternative splicing, common to most human genes and the major mechanism leading to proteomic diversity and morphological and functional complexity in eukaryotes. Alternative splicing is very important in generating functional diversity in the central nervous system (CNS), where it takes part in more than $80 \%$ of primary transcript processing. Among these is the Fragile Mental Retardation 1 gene (FMR1), which undergoes alternative splicing of four exons creating the possibility of 20 non-redundant FMRP isoforms. The aims of this project were (i) to analyze the expression of rat Fmr1 exon 12 in frontal cerebral cortex, hippocampus, and cerebellum at E19 and P2 days; and (ii) to search for cis-acting elements regulating exon 12 splicing.

We performed real-time RT-PCR to examine Fmr1 exon 12 expression, in the above-mentioned CNS structures, between the end of embryonic period and the second postnatal day. We observed significant inclusion of exon 12 in Fmr1 mRNA in frontal cortex at P2 as compared to E19, which was unrelated to general Fmr1 expression increase. At P2 hippocampus there was a significant increase at the expression levels of Fmr1, and a trend to exclude exon 12 from the primary transcript. This data indicates that cerebral cortex is an important source of proteins activating exon 12 splicing, and also a tissue where the functional relevance of FMRP isoforms expressing exon 12 should be regarded.

We adopted the mini-gene approach to search for cis elements regulating Fmr1 exon 12 splicing. RTPCR was performed to evaluate C6 (rat glioma) cells overexpressing a clone containing a genomic Fmr1 segment. Transfected cells revealed preferential inclusion of Fmr1 exon 12. A deletion construct lacking the initial bases of intron 12 was generated. The deleted segment harbor U- and C-rich sequences that had been identified in silico in a search for intronic splicing enhancers. Overexpression of the deletion construct in C6 yielded to preferential exclusion of exon 12, as opposed to the expression pattern previously observed in the original clone. Therefore, the U- and C-rich elements at Fmr1 intron 12 are strong candidates to enhance Fmr1 exon 12 splicing. 


\section{INTRODUÇÃO}

A arquitetura celular de procariontes é bastante distinta da de eucariontes. Enquanto a célula de um procarionte possui apenas um compartimento onde todos os processos celulares ocorrem, a célula eucarionte tem diversas organelas que compartimentabilizam muitas reações em seu interior. Esta diferença é importante para a expressão gênica, uma vez que em procariontes os ribossomos iniciam a tradução do ácido ribonucléico (RNA) mensageiro (RNAm) logo que o ácido desoxirribonucléico (DNA) é transcrito pela polimerase e, em eucariontes, estes processos são separados ente o núcleo e o citoplasma. No núcleo eucarionte, a transcrição é seguida pelo processamento do RNA e a tradução ocorrerá após o transporte desta molécula madura para o citoplasma. O processamento do RNA é composto por diversas etapas. Inicialmente uma guanina é adicionada ao nucleotídeo 5' do RNA nascente, criando uma ligação 5'-5' com ponte tri-fosfato, seguida da metilação da guanosina, que recebe o nome de cap. Outra característica particular em eucariontes é a presença em seus genes de sequências transcritas não codificadoras que são removidas do transcrito primário do RNA pelo processo denominado splicing. No RNAm eucarionte em processamento, ocorre ainda a poliadenilação, em que há clivagem da região 3' à qual será posteriormente adicionada uma sequência de adeninas (A) conhecida como cauda poli-A (Fig. 1, Alberts, 2002).

O splicing referido acima é o processamento de uma só molécula de RNA, denominado splicing em cis, por diferir do splicing em trans, no qual transcritos de origens diferentes sofrem ligação, e do auto-splicing (self-splicing) de íntrons de genes de organelas ou de RNA transportador (RNAt) ou ribossomal (RNAr) de raras espécies. Referimo-nos aqui somente ao splicing em cis, que foi abreviado como splicing, e é tido hoje como um mecanismo-chave na regulação da expressão gênica de eucariontes (N.A.). O que se conhece deste processamento do transcrito primário de RNA foi elucidado nas últimas três décadas. 

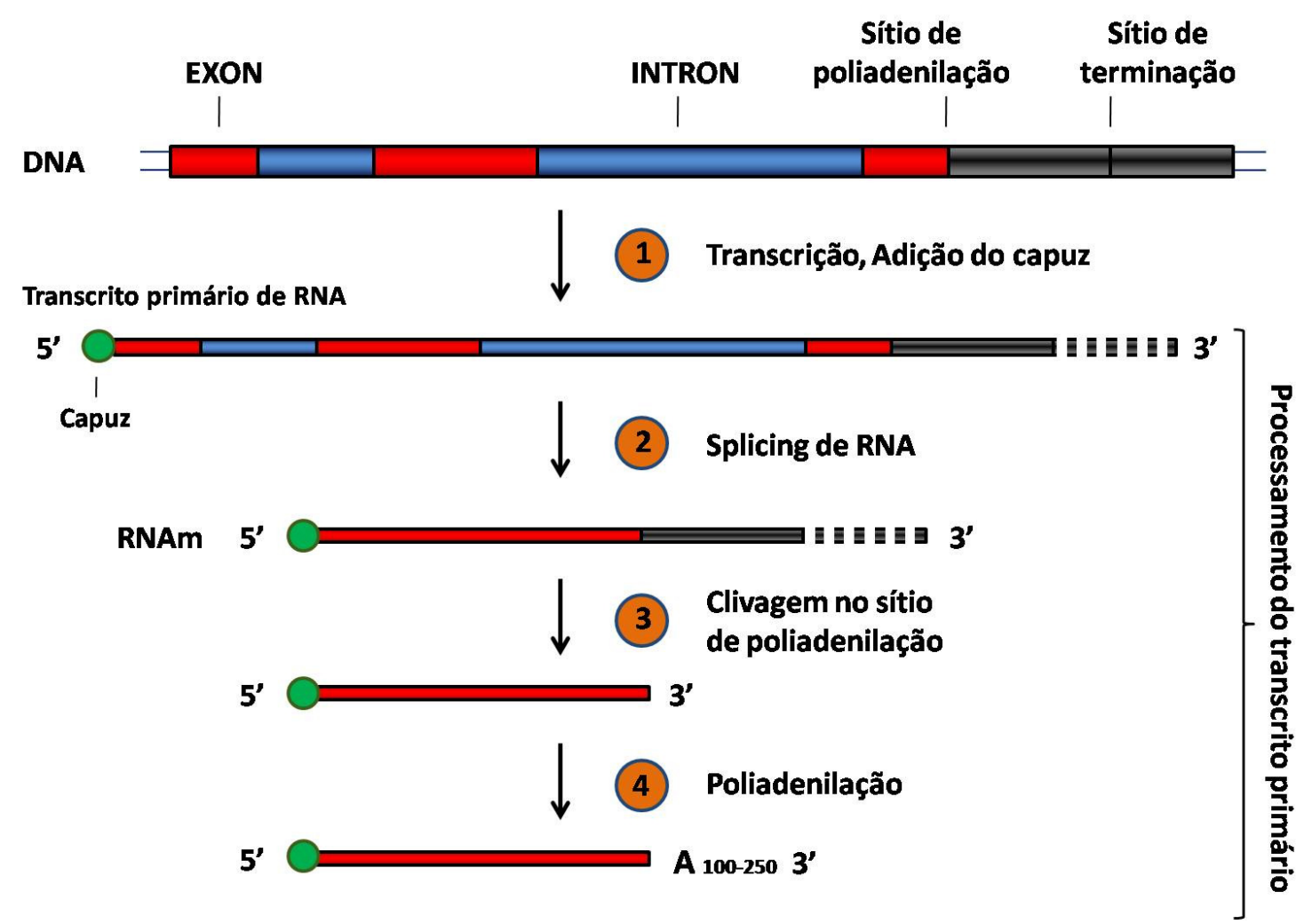

Figura 1: Etapas do processamento do transcrito primário de RNA. Inicialmente o RNA recém transcrito recebe uma guanina modificada, o capuz, em sua extremidade 5'. O trasncrito então sobre splicing, no qual os íntrons são removidos e os éxons unidos na ordem original. Na sua porção 3' o RNA possui um sítio de clivagem e poliadenilação no qual a molécula será clivada para a adição da cauda de poli-A. 


\section{Splicing: 'corte e emenda' do transcrito primário de RNA}

Em 1977, mapeamentos de restrição nos genes da Ovoalbumina de galinha, Globina beta de coelho e cadeia leve de Imunoglobulina murino mostraram que estas sequências de DNA possuíam segmentos intragênicos ausentes em seus transcritos (Brack \& Tonegawa, 1977; Breathnach et al, 1977; Doel et al., 1977; Jeffreys \& Flavell, 1977). Estas observações foram comprovadas para estes e genes virais, com sondas intragênicas de DNA que não demonstraram capacidade de hibridar com o RNA expresso pelo respectivo gene (Aloni et al., 1977). Outros autores observaram, ao microscópio eletrônico, alças em hibridações de DNA de fita simples e RNA mensageiro do gene Hexon de adenovírus e de Imunoglobulina murina. Estes dados evidenciaram que segmentos contíguos no RNA estavam interrompidos no DNA (Berget et al., 1977; Brack e Tonegawa, 1977; Dunn e Hassell, 1977).

Em 1978, já se dispunha de evidências sobre interrupções em mais de uma dezena de genes e sobre o padrão de conservação das posições dessas sequências intercaladas entre genes ortólogos e parálogos (Jeffreys e Favell, 1977; Strair et al., 1977; Lawn et al., 1978; van den Berg et al., 1978). O cístron, uma correspondência linear entre uma sequência gênica e uma polipeptídica, não era mais um modelo único. Gilbert (1978) cunhou o termo íntron para sequência intragênica, que se diferenciava da sequência gênica, expressa, que foi denominada éxon. Blake (1979) definiu íntrons como sequências intercaladas. O modelo de Gilbert (1978) propunha o gene eucarionte como um mosaico de sequências expressas, em uma matriz intrônica, silenciosa, e sugeria que éxons teriam agido como aceleradores evolutivos, criando diversidade protéica em novas proteínas, ao utilizar blocos de proteínas já existentes. $\mathrm{Na}$ época, observara-se que o tamanho dos íntrons era variável e geralmente maior do que o segmento expresso e vislumbrava-se que o conjunto intrônico deveria exceder em cinco a dez vezes o tamanho do conjunto exônico de um genoma (Gilbert, 1978). Alguns dados disponíveis sobre sequências gênicas e peptídicas por elas codificadas levaram Blake (1978 e 1979) a sugerir que éxons individuais poderiam definir 
pequenas unidades peptídicas funcionais, domínios ou dobramentos da cadeia peptídica.

Modelos foram propostos em 1977 para explicar a formação de um RNAm linear a partir de sequências transcritas de um gene interrompido (Sambrook, 1977). Esses incluíam (i) saltos pela polimerase de RNA entre sequências gênicas expressas, mas interrompidas; (ii) recombinação de DNA, criando arranjos lineares, de sequências expressas, contíguas, que serviriam de molde para a polimerase de RNA; (iii) transcrição independente para cada segmento expresso pelo mesmo gene, seguida de ligação dos transcritos e formação de um só RNAm; ou (iv) existência de um transcrito precursor que, por clivagem e ligação de fragmentos, geraria uma forma mais curta de RNAm. A maioria dos pesquisadores concordava na alta probabilidade de 0 mecanismo envolver a ligação de segmentos de ácido nucléico, tendo então sido denominado splicing (Berget et al., 1977; Crick, 1979). Um desafio era descobrir se haveria um mecanismo universal.

Em 1979, Murray e Holliday propuseram um mecanismo de splicing baseado na existência de um precursor de RNA, então chamado pré-RNAm, que foi concebido como o RNA heterogêneo nuclear (hnRNA), como discutido por Williamson (1977) e demonstrado em núcleos de várias espécies de eucariontes em mais de dez anos que se antecederam (Soeiro et al., 1966). No modelo de Murray e Holliday, haveria hibridação entre o hnRNA e um tipo de RNA pequeno, que eles definiram como 'RNA mediador de splicing' (do inglês, splicer RNA).

A hipótese de que haveria RNAs, que não o próprio pré-RNAm, que mediaria o splicing no núcleo foi corroborada por Lerner e cols. (1980) e Rogers e Wall (1980). No final da década de 1960, tinha-se identificado RNAs, em gradientes de sacarose de núcleo de células hepáticas, que sedimentavam entre $4 S$ e $7 S$ (coeficiente de Svedberg), como um pico bem distinto dos picos de RNAr e seus precursores. Análise cromatográfica desses RNAs demonstrou haver uma fração de $4 S$ a $6 S$, rica em uridina e diferente do RNAr 5S (Muramatsu et al., 1966; Weinberg et al., 1967; Hodnett 
e Busch, 1968; Nakamura et al., 1968), que foi posteriormente denominada por Weinberg e Penman (1968) como RNAs nucleares pequenos (snRNA, do inglês, small nuclear RNA) contendo entre 90 e 220 bases. Entre 1979 e 1980, os snRNAs foram identificados como integrantes de complexos ribonucleoprotéicos mediadores do splicing, através de imunoprecipitação com soro de pacientes com lupus eritematoso sistêmico, cujos auto-anticorpos eram dirigidos a esses RNAs (Lerner e Steitz, 1979; Lerner et al., 1980). Lerner e Steitz (1979) mostraram também que os snRNAs coimunoprecitavam com proteínas, sugerindo a existência de um complexo, como havia sido proposto por Raj e cols. (1975) após Enger e Walters (1970) revelarem que snRNAs podem sedimentar em complexos de até $30 \mathrm{~S}$. Mais tarde, demonstrou-se que o soro de pacientes inibia o splicing in vitro (Yang et al., 1981; Padgett et al., 1983).

Catterall e cols. (1978) relataram que as junções entre éxons e íntrons continham sequências curtas com similaridades intra- e intergênicas, que deveriam sinalizar onde ocorreria o splicing, o mesmo sendo observado para os limites entre íntrons e éxons. Estas similaridades iam além das bases conservadas nas extremidades 5' e 3' intrônicas, respectivamente GT e AG. Rogers e Wall (1980) revelaram que a junção éxon-intrônica e, sobretudo, a região 5' intrônica alinhava-se por complementaridade com parte da sequência do snRNA U1, ao contrário dos demais snRNAs U2, U4, U5 e U6 cujas funções ainda eram desconhecidas. Embora Rogers e Wall (1980) tenham inferido que a extremidade $3^{\prime}$ intrônica teria também potencial para se alinhar com o snRNA U1, Oshima e cols. (1981) indicaram maior potencial de complementaridade entre o snRNA U2 e sequências exônicas e sugeriram que esta se estenderia à extremidade 3' intrônica. Análises mutacionais confirmaram ser o snRNA U2 responsável pelo reconhecimento do sítio 3' intrônico ou receptor de splicing (Parker et al., 1987). Estes dados individualizaram a complementaridade de snRNAs em relação aos sítios intrônicos do hnRNA e sugeriam papéis independentes para U1 e U2. 
As unidades peptídicas integrantes dos complexos snRNPs começaram a ser caracterizadas individualmente a partir dos estudos de Raj e cols. (1975) através de cromatografia de extratos nucleares, e de Lerner e cols. (1980) com imunoprecipitações usando soros anti-snRNA. Algumas evidências apontavam para um conjunto protéico comum para as snRNPs U1, U2, U4, U5 e U6. No entanto, Kinlaw e cols. (1982) demonstraram haver polipeptídios únicos a cada um desses snRNPs, além de outros em comum. Embora as análises iniciais, até o começo da década de 1980, estimassem em poucas dezenas o número de polipeptídios integrantes de snRNPs (Raj et al., 1975; Stevenin et al., 1977; Howard, 1978; Lerner e Steitz, 1979; Lerner et al., 1980; Pederson e Davis, 1980; Kinlaw et al., 1982, 1983; Bringmann et al., 1983; Hintenberger et al., 1983; Sri-Widada et al., 1983; Bringmann e Luhrmann, 1986), mais de 150 peptídios diferentes já foram até hoje identificados nesses complexos (Zhou et al., 2002; revisto por Schellenberg et al., 2008).

Um avanço fundamental ao entendimento do mecanismo de splicing foi o desenvolvimento de protocolos para realização de splicing in vitro em extratos nucleares (Blanchard et al., 1978; Green et al., 1983; Hernandez e Keller, 1983; Padgett et al., 1983; Goldenberg, 1984; Krainer et al., 1984). Com esta estratégia, o uso de RNAse e a análise de intermediários de RNA no processo, identificou-se que o splicing é um mecanismo realizado em duas etapas. Inicialmente, há clivagem no sítio intrônico a 5' (Grabowski et al., 1984; Ruskin et al., 1984), seguida de ligação do fosfato na extremidade 5' a uma adenosina intrônica, interna (Konarska et al., 1985). Este componente intermediário no processo de splicing foi descrito como um RNA com estrutura em laço (do inglês, lariat), que contém um único nucleotídeo no ponto de ramificação e migra mais rapidamente em géis de acrilamida submetidos à eletroforese, dada sua natureza circular (Grabowski et al., 1984; Padgett et al., 1984; Ruskin et al., 1984). Konarska e cols. (1985) caracterizaram mais amplamente o intermediário de lariat, demonstrando que a adenosina do ponto de ramificação, por uma ligação fosfodiéster convencional, 3'-5', liga-se à base seguinte e, de forma não 
convencional, 2'-5', à base na extremidade 5' intrônica; e que este ponto de ramificação está, na sequência de adenovírus utilizada no ensaio, a 24 bases da extremidade 3', intrônica.

Após a formação do intermediário de lariat e antes da conclusão do splicing in vitro, observava-se uma eficiente recuperação do produto final, o RNAm. Isto sugeria que os segmentos de RNA permaneciam ligados a um complexo molecular durante o splicing e não eram degradados. Partículas de $40 S$ e $60 S$ com capacidade de realizar splicing in vitro foram isoladas de gradientes de glicerol de extratos nucleares, respectivamente de levedura e células HeLa, e designadas corpúsculo de splicing (do inglês, splicing body ou spliceosome; Grabowski et al., 1985; Brody e Abelson, 1985; Frendewey e Keller, 1985).

A primeira reação do splicing foi elucidada com a participação dos snRNPs U1 e U2. Demonstrou-se posteriormente que a atuação dos snRNAs U4 e U6 era essencial ao splicing mas independente de U1 e U2 (Berget e Robberson, 1986; Black e Steitz, 1986). Outros estudos revelaram que U4 e U6 têm uma extensa região de complementaridade que permite a formação de um complexo snRNP U4-U6 (Guthrie e Patterson, 1988), que se liga a snRNP U5, e é este complexo de três partes que se associará ao complexo denominado $A$, em que se encontram os snRNPs U1 e U2 ligados respectivamente aos sítios doador e receptor de splicing, com o íntron do hnRNA em forma de arco (Konarska e Sharp, 1987). A reunião em complexo dos cinco snRNPs culmina na formação do spliceossomo propriamente dito (complexo B). Rearranjos internos por maior afinidade entre novos membros do grande complexo alteram sua conformação o que permite acontecer a primeira reação do splicing - a formação do intermediário de lariat. A segunda reação do splicing não mais depende do snRNP U1, é conseqüente à primeira e consiste de união dos éxons consecutivos com liberação do lariat e separação das subunidades do spliceossomo (Konarska e Sharp, 1987). 
Apesar da grande complexidade e diversidade protéica do corpúsculo do splicing, duas proteínas foram evidenciadas por sua importância para hibridação dos snRNAS U1 e U2 respectivamente aos sítios doador e receptor de splicing. O fator auxiliar de U2 (U2AF) é composto por duas subunidades, uma de $35 \mathrm{kDa}$ (U2AF35) e outra de 65 kDa (U2AF65) que reconhecem respectivamente o sítio receptor de splicing e o trato de poli-pirimidina (Ruskin et al., 1988; Zamore e Green, 1990). A especificidade para a interação de U2AF35 ao sítio receptor de splicing foi posteriormente consolidada por experimentos em várias espécies e demonstrou-se ser dependente do dinucleotídeo AG, o que explica a incerteza do reconhecimento pelo snRNA U2 anteriormente levantada (Merendino et al., 1999; Wu et al., 1999; Zorio e Blumenthal, 1999). O fator de splicing 1 (SF1), identificado por Krainer e Maniatis (1985), foi revelado como uma proteína que coopera com U2AF para identificação do ponto de ramificação (Kramer e Utans, 1991; Berglund et al., 1997; Berglund et al., 1998). A sequência da atuação dos vários snRNPs foi posteriormente definida por abordagens experimentais semelhantes às descritas.

A necessidade de um spliceossomo extenso constituído por diversos elementos reside na distância entre os sítios de splicing no íntron e na especificidade destes e sequências adjacentes (Fig. 2A), uma vez que as reações em si são relativamente simples. Como visto, a reação do splicing é realizada por centros catalíticos nas ribonucleoproteínas e é constituída por duas trans-esterificações, em que a ligação covalente entre uma hidroxila e um grupo fosfato é transferida diretamente de um nucleotídeo para outro em um único passo, não ocorrendo, portanto, clivagem e ligação, como se propôs. Na primeira trans-esterificação, mediada por U2 e U6, a hidroxila livre na posição 2' da adenosina invariável do ponto de ramificação, ataca o grupo fosfato da base na extremidade 5' do íntron, criando uma ligação fosfodiéster não convencional, 2'-5', que coloca o íntron em forma de laço. Como consequência, uma alteração na interação entre as snRNPs, principalmente U5, altera a estrutura secundária do RNA, aproximando os éxons que são unidos na segunda reação de 
transesterificação em que a hidroxila do último nucleotídeo livre do éxon a 5', que foi liberado na primeira reação, ataca o grupo fosfato do primeiro nucleotídeo do éxon adjacente na região do sítio receptor (Fig. 2). Esta reação liga éxons consecutivos, liberando o íntron ainda na forma de laço que será posteriormente degradado. Desta forma, a reação de um spliceossomo em cada íntron do gene resultará em uma molécula de RNAm constituída pelos segmentos exônicos na ordem em que estes se apresentavam na sequência genômica (Padgett et al, 1986). 


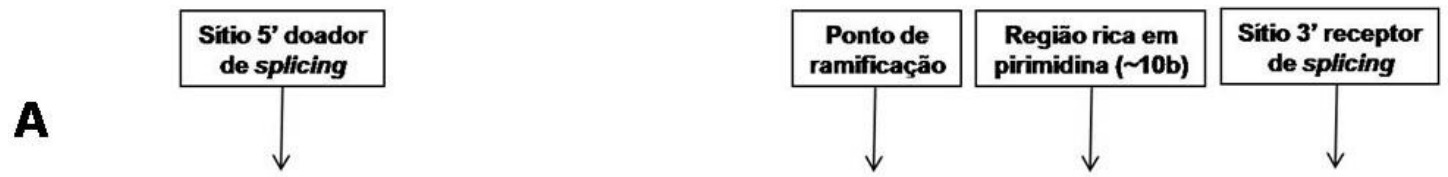

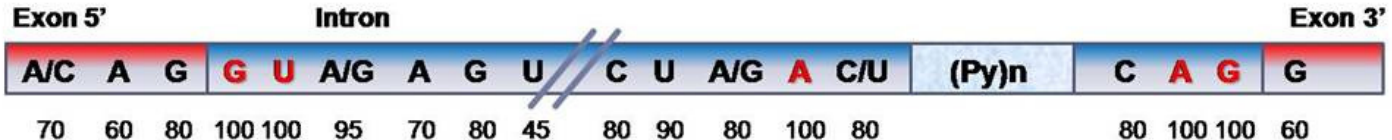

B
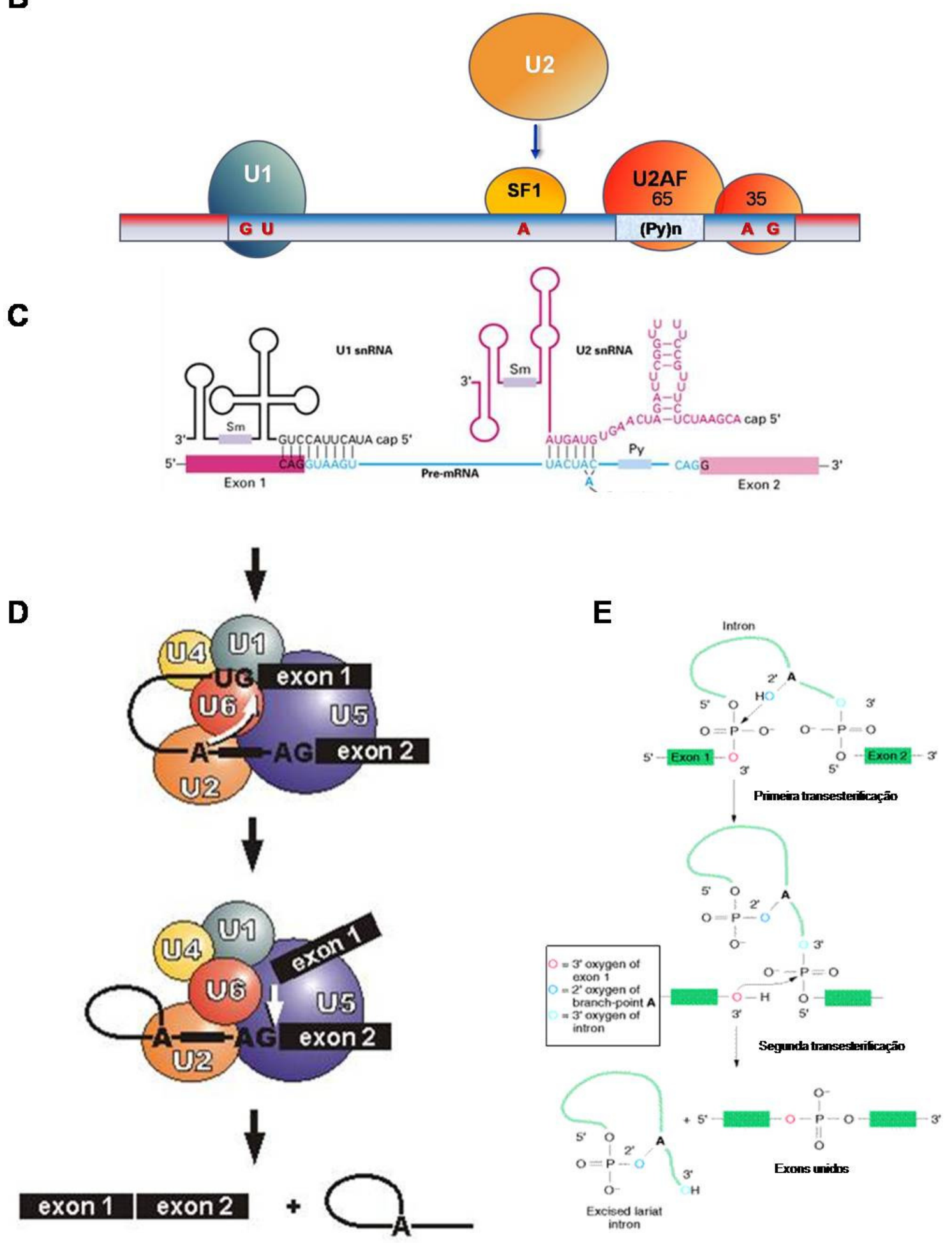
Figura 2: (A) Representação da estrutura de um íntron eucarionte mostrando as principais sequências conservadas e as frequências de seus respectivos nucleotídeos em vertebrados. $O$ mecanismo através do qual as unidades constituintes do spliceossomo realizam o splicing está relacionado diretamente com a estrutura do íntron. Nas sequências dos íntrons existem segmentos conservados com cerca de cinco nucleotídeos, dos quais os mais importantes se encontram na periferia, nas fronteiras entre éxons e íntrons, sendo respectivamente o doador a 5' (A/C A G G U Pu A G U em vertebrados) e aceptor a 3' (C A G G em vertebrados). Dentro destes consensos a maioria das bases não apresenta grande conservação entre os grupos de eucariontes, no entanto, os dinucleotídeos mais extremos no íntron, guanina e uracila a 5' e adenina e guanina a 3' (representados em negrito), estão presentes em quase todos os íntrons. Outros elementos conservados estão localizados na região terminal do íntron, a cerca de 50 bases de seu término, sendo um consenso denominado ponto de ramificação ( $C \cup \mathrm{Pu} A \mathrm{Py}$ ), com baixa conservação com exceção de uma adenosina invariável (representada em negrito), e um segmento de extensão variável, com cerca de 10 bases, composta por pirimidinas, denominado trato de polipirimidinas.

(B) Modelo da interação das unidades integrantes do spliceossomo com o íntron eucarionte. As ribonucleoproteínas nucleares (snRNPs) interagem com os sítios conservados por emparelhamento de bases. A snRNP U1 reconhece o sítio doador a 5' do íntron, enquanto 0 fator protéico SF1 interage com o ponto de ramificação. A proteína acessória de U2 (U2af), possui duas subunidades, sendo uma de 65KDa e uma de $35 \mathrm{KDa}$, que interagem respectivamente com a trato de polipirimidinas e com o sítio aceptor de splicing a 3' do íntron. Recrutado por U2af U2 se liga ao ponto de ramificação deslocando SF1.

(C) Emparelhamento de bases entre os snRNAs U1 e U2 respectivamente no sítio doador e ponto de ramificação no íntron.

(D) Esquema das alterações conformacionais causados pelo spliceossomo (U1, U2, U4, U5 e U6) sobre o transcrito primário, aproximando os sítios envolvidos nas duas reações de transesterificação que levam ao splicing. Inicialmente a primeira guanina do íntron é ligada a adenosina do ponto de ramificação, fazendo com que o íntron assuma a forma de laço, e posteriormente os éxons consecutivos são unidos, liberando o íntron.

(E) Representação das duas reações de transesterificações que são responsáveis pela excisão do íntron durante o splicing. Na primeira transesterificação a hidroxila 2' livre da adenosina do ponto de ramificação ataca o grupo fosfato da guanina inicial do íntron. Na segunda reação a hidroxila 3' da ultima base do éxon 1 ataca o grupo fosfato 5' no ínicio do éxon 2, unindo os éxons adjacentes. 


\section{Splicing alternativo}

Em 1980, cDNA codificador para imunoglobulinas com distribuições subcelulares distintas, sendo uma secretada e outra integrada à membrana celular, foram clonados. A análise das sequências das moléculas de RNAm responsáveis pela síntese destas duas isoformas mostrou perfeita identidade, exceto em suas regiões 3'. A comparação destes com sequências genômicas apontou que os dois RNAs deveriam ser produzidos a partir de um mesmo gene e que as diferenças entre eles seriam decorrentes da utilização de diferentes combinações de éxons na região terminal. A inclusão de um ou outro éxon determinaria os códons para domínios responsáveis pela localização diferencial das duas isoformas de imunoglobulinas. Foi interessante observar que esses éxons eram excludentes, isto é, a inclusão de um excluiria o outro. Este mecanismo de splicing regulado foi considerado uma alternativa de splicing com éxons mutuamente excludentes (Alt et al, 1980; Early et al, 1980).

Em 1981, observou-se que a sequência genômica do gene do hormônio de crescimento humano tinha um íntron em sua extremidade 3' com duas possibilidades para sítios receptores de splicing. Experimentos de Northern blotting com sonda de cDNA revelaram duas formas de splicing deste íntron do hnRNA do gene do hormônio de crescimento humano, sendo que em uma delas haveria encurtamento exônico. Este relacionava-se a um aumento da sequência intrônica excluída. Tratava-se de sítios receptores alternativos de splicing (DeNoto et al, 1981). Da mesma forma, sítios doadores alternativos de splicing foram identificados, na época, no gene Ddc de Drosophila (Morgan et al, 1986). Um mecanismo menos comum de splicing alternativo é a retenção intrônica e não será discutido aqui (Fig. 3).

A partir dessas descrições, exemplos de genes que produziam mais de uma variante de RNA mensageiro foram inicialmente apresentados na família das imunoglobulinas e depois estendidos a outros genes. Definiu-se o termo splicing alternativo para explicar as alternativas de utilização regulada dos sítios de splicing, definindo inclusão ou exclusão total ou parcial de éxons e gerando variantes para a 
sequência final do RNA mensageiro, originadas de um mesmo gene. Esta variabilidade, se localizada na região codificadora do RNAm, leva à síntese de formas variantes da mesma proteína, denominadas isoformas, por analogia ao conceito de isoenzimas, definido por Markert e Moller (1959), como formas moleculares diferentes nas quais proteínas podem existir sem diferir na especificidade enzimática. Embora se assumisse que o splicing alternativo fosse funcional, a ocorrência estimada deste evento do processamento do hnRNA era em torno de 5\% para o genoma humano por na década de 1990 (Hanke et al, 1999).

\section{Sítios 5' alternativos}

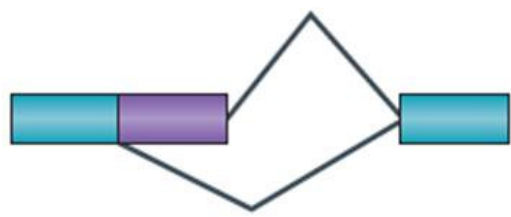

Exons cassete

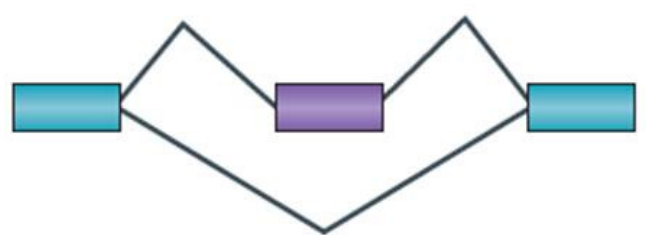

Sítios 3' alternativos

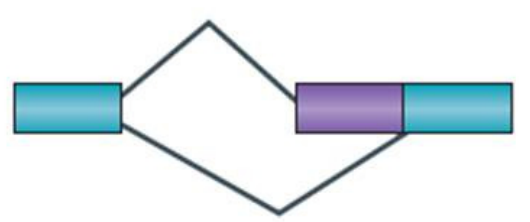

Sítios 5' alternativos

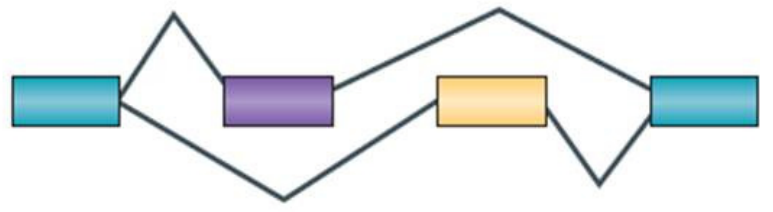

Retenção intrônica

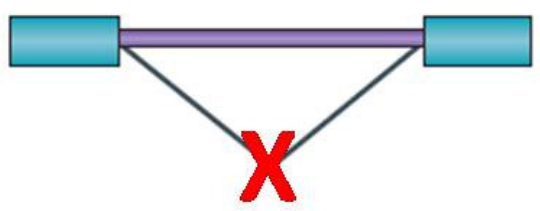

Figura 3: Modos de splicing alternativo. Sítios alternativos no íntron a 5' (doador) ou a 3' (aceptor) levam a criação de éxons com extensões variáveis no transcrito final. Éxons cassete por sua vez tem sua sequência completa incluída ou excluída do RNAm. A retenção intrônica consiste na permanência da sequência completa de um íntron no transcrito maduro. Fonte: Lee \& Black, 2007. 
O entendimento do splicing alternativo teve grande contribuição de projetos de sequenciamento de genomas. O projeto Genoma Humano permitiu a criação de bancos de dados, desenvolvimento tecnológico e a disponibilização pública de sequências que possibilitaram a expansão do foco dos estudos genômicos para uma escala global e também transcricional. Duas iniciativas de sequenciamento, sendo uma pública e uma privada, apresentaram paralelamente seus resultados preliminares em 2001, com cerca de 90\% do genoma humano publicado (Lander et al, 2001; Venter et al, 2001), e uma versão finalizada três anos mais tarde com uma precisão de 99,99\% (IHGSC, 2004). Este projeto gerou grandes contribuições para a compreensão da estrutura e funcionamento do genoma humano. Entre elas, observou-se que das cerca de 2,85 bilhões de bases, apenas $1.2 \%$ correspondia a sequências expressas, constituindo cerca de 22.000 genes.

A estimativa do número de genes humanos menor do que anteriormente previsto deixou claro que a complexidade dos organismos, principalmente entre os grupos mais derivados de eucariontes, não podia ser explicada unicamente pela sua quantidade de genes, mas provavelmente por processos de regulação gênica refinados (Antequera \& Bird, 1993; Ewing \& Green, 2000; Lander et al, 2000; Roest-Crollius et al, 2000; Dunham, 2001; IHGSC, 2004). A partir desta impressão, intensificou-se a busca por mecanismos de regulação nestes organismos que pudessem explicar sua variabilidade proteômica. Diversos, como sítios alternativos de poliadenilação e códons alternativos de início e término de tradução alternativos foram estudados. Juntos estes mecanismos possibilitam que o proteoma desses organismos tenha uma variabilidade uma ordem de grandeza maior do que seu genoma, sendo que entre estes mecanismos, o splicing alternativo é considerado o mais prevalente (Fields, 2001).

\section{Regulação do splicing alternativo}

Estudos funcionais têm buscado compreender como se dá a regulação fina do splicing alternativo e se as diferenças de frequência deste processo, entre as 
espécies, tem relevância funcional. Uma observação importante dos estudos genômicos é que os sítios de splicing nas espécies mais derivadas podem apresentar sequências menos similares aos consensos, conferindo flexibilidade à sua interação com o spliceossomo. Estas diferenças podem ser percebidas pela comparação de sequências dos sítios de splicing entre os íntrons de leveduras e mamíferos. No primeiro grupo, há um índice relativamente baixo de genes com íntrons e, nestes, os sítios são altamente conservados, interagindo fortemente com as unidades do spliceossomo, sendo pouco susceptíveis a alterações no padrão de splicing. Em mamíferos, há relativa degeneração dos sítios de splicing em relação à sequênciaconsenso, o que repercute na interação destes com o spliceossomo. Fatores que vêm sendo observados influenciando a fidelidade na escolha do sítio de splicing ou o fortalecimento de sítios de splicing degenerados incluem: o tamanho do éxon, a estrutura secundária do RNA nascente, a processividade da polimerase de RNA e sequências acessórias, transcritas (Ast, 2004).

As sequências acessórias são fatores importantes nos eventos de splicing regulado. Elas são transcritas, sendo, por isso, consideradas elementos em cis. São curtas, compostas por menos de dez bases, degeneradas dentro da classe, altamente variáveis e podem ter repetições internas degeneradas ou serem ricas em purinas na sequência do RNA (Blencowe, 2006). Estes elementos regulatórios, em cis, foram observados inicialmente em estudos genéticos de Saccharomyces cerevisiae buscando por mutações que alteravam a interação com o spliceossomo (Newman, 1987). No ano seguinte foram identificados elementos em íntrons humanos que analogamente podiam inibir a ligação dos elementos do spliceossomo aos sítios de splicing (Furdon \& Kole, 1988). Mais tarde, foram descritos diferentes elementos exônicos, ricos em purinas, que possuíam a capacidade de acentuar ou inibir a inclusão do éxon no RNA maduro (Sun et al, 1993). Elementos ricos em guanina em íntrons foram posteriormente identificados como acentuadores (do inglês, enhancer) da reação de splicing. Estes estudos mostraram que estes elementos em cis podiam 
estar presentes tanto em sequências de éxons quanto em íntrons, influenciando o splicing de diferentes maneiras, a grandes distâncias e de forma aparentemente independente da posição relativa a seu alvo, sendo categorizados em quatro classes: os acentuadores exônicos do splicing (ESE, do inglês, exonic splicing enhancer), os silenciadores exônicos do splicing (ESS, do inglês, exonic splicing silencer), os acentuadores intrônicos do splicing (ISE, do inglês, intronic splicing enhancer) e os silenciadores intrônicos do splicing (ISS, do inglês, intronic splicing silencer, Blencowe, 2006).

Foi proposto que a atuação destas sequências acessórias sobre a decisão de utilização de sítios de splicing deveria ocorrer por intermédio de elementos protéicos, o que era já sugerido em estudos de deleção (Newman, 1987; Cooper \& Ordahl, 1989). Estes fatores protéicos são elementos em trans que interagem especificamente com os elementos em cis no RNA e com elementos da maquinaria de splicing. Os elementos em trans foram identificados, a partir de 1988, no splicing constitutivo (Schenkel et al, 1988; Spector et al, 1991; Ge et al, 1991). A interação direta de um elemento em trans ao elemento em cis e ao spliceossomo só foi demonstrada posteriormente (Sun et al, 1993). Nos últimos quinze anos, foi possível classificar diversos fatores em trans de acordo com as estruturas primária a quaternária dessas proteínas e as sequências de RNA às quais elas se ligam (Tabela 1). Cada nova identificação de associação entre elementos em cis e em trans depende de estudos experimentais trabalhosos, dirigidos ao éxon específico de um gene em particular e desenvolvidos através de estratégias experimentais que se iniciam pela clonagem de mini-genes e sua expressão em células de eucariontes, e continuam com análises de mutagênese, interação RNA-proteína e estudos funcionais de splicing in vitro para demonstrar a relevância biológica da interação (Cooper, 2005).

Os fatores em trans têm pelo menos um domínio de interação ao RNA e domínio(s) de interação protéica, através do(s) qual(is) eles interagem com componentes do spliceossomo (revisto por Blencowe, 2006). Esta relação entre elementos em cis e em 
trans foi observada inicialmente nos ESEs, reconhecidos especificamente por proteínas da família $S R$ (rica em serina e arginina, $S$ e $R$, respectivamente). As proteínas desta extensa família possuem em comum um domínio de ligação ao RNA do tipo RRM (do inglês, RNA recognition motif) através do qual interagem com o elemento em cis, e um domínio $\mathrm{RS}$, rico em repetições de arginina $(\mathrm{R})$ e serina $(\mathrm{S})$, que promove a interação da proteína com o spliceossomo. Uma consequência da interação entre ESEs, proteínas SR e o spliceossomo é a intensificação da afinidade do emparelhamento RNA:RNA, favorecendo o splicing naquele sítio.

A identificação de ESEs em vários éxons, em estudos sobre o splicing constitutivo, demonstrou a importância das proteínas SR neste processo, e levou à criação do conceito de 'definição exônica' (Fig. 4), em que a distinção entre éxon e íntron não depende apenas das sequências de splicing conservadas nos íntrons, mas também da presença das sequências acentuadoras nos éxons. Este conceito é aplicado principalmente a mamíferos onde este fenômeno é observado devido a característica degenerada de seus sítios de splicing, ao contrário de leveduras, em que o processo de splicing não é dependente das proteínas SR dada a alta conservação de seus sítios que garante a afinidade pelas snRNPs do spliceossomo (revisto por Black, 2003). As proteínas SR interagem com o domínio C-terminal da polimerase II de RNA, que é regulado por fosforilação ao início da transcrição gênica. Outras proteínas que participam do processamento do hnRNA também se associam a este domínio, possibilitando o recrutamento das maquinarias do processamento, que ocorre de forma co-transcricional no transcrito nascente (Bentley, 1999). 


\begin{tabular}{|c|c|c|c|c|}
\hline & Nome & Outros nomes & Domínios & Sítio s de ligação \\
\hline \multirow{13}{*}{ 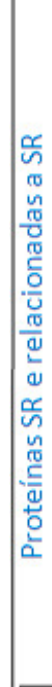 } & SRp20 & Sfrs3, X16 & RRM, RS & GCUCCUCUUC \\
\hline & 9G8 & Sfrs7 & RRM, RS, C2HC Znf & (GAC)n \\
\hline & ASF/SF2 & Sfrs1 & RRM, RS & RGAAGAAC \\
\hline & SC35 & Sfrs2 & RRM, RS & UGCUGUU \\
\hline & SRp30c & Sfrs9 & RRM, RS & CUGGAUU \\
\hline & SRp38 & Fusip1, Nssr & RRM, RS & ACAAAGACAA \\
\hline & SRp40 & Sfrs5, HRS & RRM, RS & AGGAGAAGGGA \\
\hline & SRp55 & Sfrs6 & RRM, RS & GGCAGCACCUG \\
\hline & SRp75 & Sfrs 4 & RRM, RS & GAAGGA \\
\hline & $\operatorname{Tra} 2 \alpha$ & Tra2a & RRM, RS & GAAARGARR \\
\hline & $\operatorname{Tra} 2 \beta$ & Sfrs10 & RRM, RS & (GAA)n \\
\hline & SRm160 & Srm1 & RS, PWI & AUGAAGAGGA \\
\hline & SWAP & Sfrs8 & RS, SWAP & ND \\
\hline \multirow{9}{*}{ 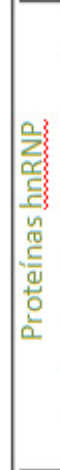 } & hnRNP A1 & Hnrnpa1 & RRM, RGG & UAGGGAUU \\
\hline & hnRNP A2/B1 & Hnrnpa2b1, Hnrnpa2 & RRM, RGG & (UUAGGG)n \\
\hline & hnRNP C & Hnrnpc, Hnrnpc1/c2 & RRM & U-rich \\
\hline & hnRNPF & Hnrpf & RRM, RGG, GY & GGGA, G-rich \\
\hline & hnRNP G & Rbmxrt, Hnrnpg & RRM, RGG, SRGY & AAGU \\
\hline & hnRNP H & Hnrph1 & RRM, RGG, GYR, GY & GGGA, G-rich \\
\hline & hnRNPL & Hnrnpl & RRM & C/A-rich \\
\hline & PTB & Ptbp1, Hnrpi & RRM & UCUU, CUCUCU \\
\hline & nPTB & Ptbp2, brPTB & RRM & CUCUCU \\
\hline \multirow{18}{*}{ 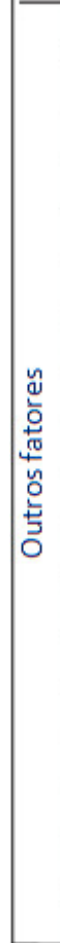 } & Fox1 & A2bp1 & RRM & (U)GCAUG \\
\hline & Fox2 & $\mathrm{Rbm9}$ & RRM & (U)GCAUG \\
\hline & Cugbp & Cugbp1, Brunol2 & RRM & U/G-rich \\
\hline & Cugbp2 & ETR-3, Brunol3 & RRM & U/G-rich \\
\hline & Celf4 & Brunol4 & RRM & U/G-rich \\
\hline & HuD & Elav14 & RRM & U-rich \\
\hline & Nova-1 & Nova1 & $\mathrm{KH}$ & YCAY \\
\hline & Nova-2 & Nova2 & $\mathrm{KH}$ & YCAY \\
\hline & TIA1 & mTia1 & RRM & U-rich \\
\hline & TIAR & Tial1, mTIAR & RRM & U-rich \\
\hline & Mbnl1 & Mbnl & С $3 \mathrm{H} 1 \mathrm{Znf}$ & $\mathrm{YGCU}(\mathrm{U} / \mathrm{G}) \mathrm{Y}$ \\
\hline & SIm-2 & Khdrbs3, T-STAR & $\mathrm{KH}$ & UAAA \\
\hline & Quaking & Qk, Qkl & $\mathrm{KH}$ & ACUAAY[...]UAAY \\
\hline & PSF & Sfpq & RRM & ND \\
\hline & SPF45 & Rbm17 & RRM, G patch & ND \\
\hline & $\mathrm{Rbm} 4$ & Rbm4a, Lark & RRM, C2HC Znf & C/U-rich \\
\hline & Sf3b1 & SAP155, SF3b155 & RRM, HEAT & ND \\
\hline & Sam68 & Khdrbs1 & $\mathrm{KH}$ & ANU-rich \\
\hline
\end{tabular}

Tabela 1: Tabela exibindo proteínas com função reconhecida de regulador em trans do splicing. As proteínas estão organizadas por famiília protéica com domínios principais e sítios de lligação ao RNA representados. Modificada de Gabut et al, 2008. 
Os silenciadores exônicos, ESS, por sua vez, são reconhecidos por ribonucleoproteínas nucleares, heterogêneas (hnRNPs), dentre as quais, a hnRNP A1 é a mais estudada. Esta proteína possui domínios de ligação ao RNA do tipo RNP-cs, através dos quais ela interage com a sequência exônica, mais exatamente com o ESS. Age como antagonista de proteínas SR, como as SF2/ASF, participando da 'definição exônica'. Se há preponderância de sua ação sobre a de proteínas SR, há exclusão deste éxon no transcrito maduro.

Os elementos em cis que agem como acentuadores intrônicos do splicing podem se localizar adjacentes ou até a algumas centenas de bases do sítio de splicing sobre o qual agem. ISEs são reconhecidos por diferentes proteínas, entre as mais comuns encontram-se a TIA1 (TIA1 cytotoxic granule-associated RNA binding protein) e CELF (do inglês, $\underline{C} U G$-binding protein and EETR-like factors). TIA associa-se a regiões ricas em uracila, e reforça a ligação de snRNPs U1 aos respectivos sítios, favorecendo o splicing (Forch et al, 2000). Desta forma, os íntrons, como os éxons, podem ser definidos pelo conjunto de proteínas a eles associado.

Os silenciadores intrônicos de splicing, ISS, são reconhecidos tanto por proteínas da família SR quanto pela hnRNP A1. Se próximo ao ponto de ramificação, pode haver ligação do ISS às proteínas SR levando, nesta posição, à inibição do splicing. A ligação de ISSs à hnRNP A1 antagoniza elementos de splicing U2 (Tange et al, 2001). Como se observa, a ação de fatores em trans na regulação do splicing depende da posição, em relação ao transcrito, do elemento em cis a ele ligado. Além disso, elementos em cis e em trans, intrônicos e exônicos de regulação de splicing agem concomitantemente durante um evento de splicing, e é o efeito combinatório deles e o spliceossomo que irá determinar o produto final deste processamento co-transcricional (Black, 2003). O efeito combinatório do splicing dependerá certamente de mecanismos regulatórios da atividade dos fatores em trans ainda não bem compreendidos. 


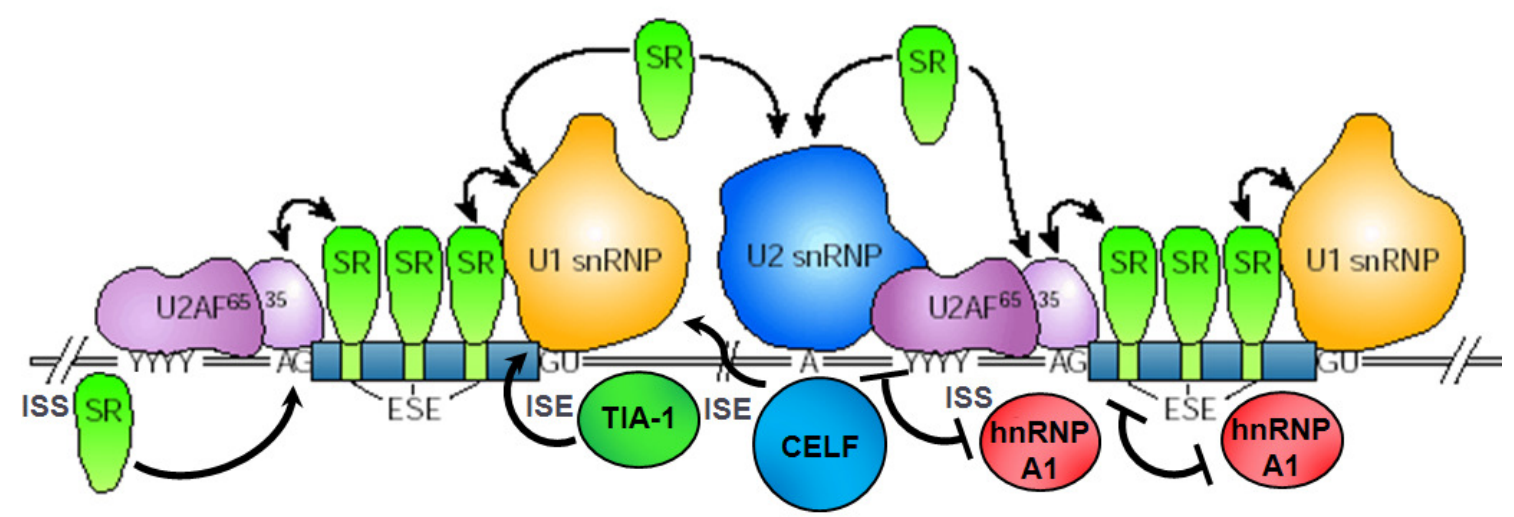

Figura 4: Definição exônica. Os sítios regulatórios em cis estão presentes em todos os éxons e íntrons, aos quais se ligam diversos elementos em trans. Estes elementos agem concomitantemente durante o splicing e seu equilíbrio define quais regiões serão definidas como éxons e íntrons. Modificado de Maniatis \& Bosiljka, 2002.

\section{Produtos do splicing alternativo}

Uma questão atual e importante é investigar que proporção dos transcritos variantes gerados a partir de um só gene irá ter repercussão funcional. Mutações novas em sítios de splicing ou em sequências acessórias, que geram produtos de splicing espúrios ou bloqueiam a excisão de íntrons, são responsáveis por diversas doenças humanas, com uma estimativa de $15 \%$ das mutações de ponto que levam a doenças genéticas humanas serem desse tipo (Krawczak et al, 1992). Por outro lado, alterações evolutivamente fixadas possibilitam regulação fina do splicing mediante sinais celulares específicos, tornando este processo um poderoso gerador de diversidade funcional. Este papel é corroborado pela observação de que o splicing alternativo é menos frequente em genes com maior número de parálogos em um dado 
genoma, e em tecidos altamente especializados como o sistema nervoso central (SNC).

A atuação do splicing alternativo como regulador da expressão gênica é evidenciada pelas funções exercidas pelas variantes criadas neste processo. Estas variantes de RNAm podem ser traduzidas, dando origem a isoformas protéicas com funções ou distribuições subcelulares distintas, como corroborado por evidências de conservação de eventos de splicing em eucariontes e de que o splicing alternativo acarreta mais comumente modificações em fragmentos codificadores do RNAm (Wen et al, 2004). Os dados de similaridade de sequências, principalmente entre os mamíferos, sugerem que pelo menos $25 \%$ das variantes geradas por splicing alternativo resultem em isoformas com ganho funcional (Sorek et al, 2004). Há uma tendência atual a estimar esta freqüência bem acima destes valores.

As variantes de RNA podem ainda conter códons de parada de tradução prematuros podendo ser direcionadas para degradação pelo sistema de vigilância da célula, decaimento mediado por sequências sem sentido (NMD, do inglês, nonsensemediated decay), um dos mecanismos responsáveis pela degradação de RNA mensageiro na célula (Lareau et al, 2004; Lejeune \& Maquat, 2005; Matlin et al, 2005). Observou-se, mais recentemente, exemplos em que os sub-produtos do splicing alternativo, os segmentos intrônicos ou exônicos não incorporados ao RNAm, podem ser substratos para a drosha, ribonuclease nuclear que atua na produção de microRNAs para controle da meia-vida do RNAm, pelo mecanismo de interferência pelo RNA, RNAi (Berezikov et al, 2007).

\section{Splicing alternativo e diversidade funcional no SNC}

A diversidade funcional gerada pelo splicing alternativo é representada por eventos específicos relacionados a períodos de desenvolvimento, tipo e atividade celular e tecidos. Foi demonstrado que o número total de genes que sofrem splicing alternativo é especialmente elevado em tecidos altamente especializados como cérebro, gônadas e fígado. Dentre estes, o SNC de mamíferos se destaca pela frequência de ocorrência 
do splicing alternativo próximo a 90\%, com diversos eventos exclusivos deste tecido (Yeo et al, 2004). Em neurônios, o splicing alternativo é proposto como o principal mecanismo responsável pelo desenvolvimento do de funções complexas deste órgão atuando na diferenciação neuro-glial, no direcionamento de axônios na sinaptogênese, modulando as respostas a neurotransmissores e gerando isoformas para todos os receptores já descritos (Lipscombe, 2005).

Um sistema bem descrito no SNC é o sinal para diferenciação e desenvolvimento neuronal pela proteína de ligação a tratos de pirimidinas (PTB) e seu parálogo neuronal (nPTB). PTB, expressa em todos os tecidos, age como um silenciador de splicing que causa a exclusão de um éxon na sua própria mensagem e na mensagem de $\mathrm{nPTB}$, criando um códon de parada prematuro que, via NMD, reduz a tradução de PTB e bloqueia a de nPTB. Na linhagem neuro-glial direcionada à diferenciação neuronal, o gene PTB é bloqueado transcricionalmente, o que permite a tradução de nPTB que regula o splicing de até $25 \%$ dos transcritos da célula desencadeando a diferenciação para linhagem neuronal (revisto por Coutinho-Mansfield, 2007).

Outro exemplo bem caracterizado é o da neurexina e neuroliguina, duas proteínas de membrana que apresentam isoformas geradas a partir de variantes criadas por splicing alternativo. Estas duas proteínas interagem na sinapse de forma que uma isoforma de uma dessas proteínas, em uma projeção neuronal pré-sináptica, reconhece especificamente apenas uma isoforma da outra em neurônio pós-sináptico, gerando assim uma identidade celular que permite a criação de sinapses exclusivas (Li et al, 2000).

Os canais de transporte de cálcio em neurônios também apresentam grande variabilidade gerada por splicing alternativo, podendo produzir até mil isoformas previstas por gene. O splicing regulado é evidenciado pela inclusão diferencial de éxons-cassete em diversos transcritos para estes canais, que apresentam uma taxa de inclusão gradativamente maior durante o desenvolvimento até a idade adulta. Em um destes genes, a inclusão de um dos éxons mutuamente excludentes altera 
domínios responsáveis pelas propriedades físico-quimicas do canal resultante, gerando uma isoforma que é inativada apenas por voltagem e outra inativada apenas por neurotransmissores, cada uma delas expressa em resposta a um sinal externo (revisto por Gray et al, 2007). Estes são poucos exemplos da diversidade funcional gerada pelo splicing alternativo no SNC.

Entre os reguladores de splicing exclusivos do SNC já identificados, a proteína de ação mais abrangente é NOVA (do inglês, Neuro-oncological ventral antigen). Identificados como auto-antígenos de expressão exclusivamente neuronal em uma síndrome paraneoplásica, as proteínas NOVA1 e NOVA2 são reguladores em trans, produzidos a partir de genes parálogos, que regulam uma grande gama de eventos de splicing, relacionados em sua grande maioria com a sinaptogênese (Blencowe, 2005). Estudos com microarrays para eventos de splicing realizados em modelos de camundongos nocaute individuais para os dois genes das proteínas NOVA detectaram alterações em 7\% dos eventos de splicing exclusivos do SNC, demonstrando a abrangência da ação destes reguladores (Jensen et al, 2000; Ule et al, 2005; Li et al, 2007).

\section{Splicing alternativo do gene do Retardo Mental do X Frágil (FMR1)}

Um dos genes expressos no SNC e que apresenta variantes geradas a partir de splicing alternativo é o gene do Retardo Mental do X Frágil (FMR1, do inglês, Fragile Mental Retardation 1 gene), clonado em 1991 (Fu et al, 1991; Kremer et al, 1991; Oberlé et al, 1991; Verkerk et al, 1991; Yu et al, 1991). O gene, com cerca de 38 Kilobases $(\mathrm{Kb})$, tem 17 éxons e é em transcrito em RNAm de $4.4 \mathrm{~Kb}$, composto por uma região 5' não traduzida (5' UTR) de $0.2 \mathrm{~Kb}$, uma região codificadora de $1.9 \mathrm{~Kb}$ e uma região 3' não traduzida (3' UTR) de 2.3 Kb (Ashley et al, 1993; Eichler et al, 1993).

Há, no primeiro éxon do gene FMR1, um microssatélite de trinucleotídeos, citosina, guanina e guanina (CGG), que é transcrito e não traduzido, presente na porção 5' UTR de seu RNAm. Estas repetições CGG fazem parte de uma ilha CpG que, se metilada, 
inativa a expressão do FMR1 (Fu et al, 1991; Verkerk et al, 1991; Bell et al, 1991). O microssatélite de trinucleotídeos apresenta polimorfismo de tamanho na população geral, com alelos de seis a cerca de 40 repetições. Pacientes com a síndrome do $X$ frágil (SXF), a causa hereditária mais frequente de retardo mental entre homens, apresentam mutações completas de trinucleotídeos CGG do FMR1, com alelos contendo mais de 200 repetições CGG, cujas citosinas e as da ilha CpG em que se encontram tornam-se metiladas, resultando na inativação do gene FMR1. Mães e avôs maternos de pacientes são portadores de pré-mutações, alelos instáveis às meioses, com cerca de 60 a 200 repetições CGG, sem metilação. Os portadores de prémutações, embora sem distúrbios de aprendizagem, podem apresentar outras afecções clínicas. Mães de crianças afetadas pela SXF podem manifestar falência ovariana prematura (Vianna-Morgante e Costa, 2000). Homens e, raramente, mulheres, portadores da pré-mutação podem vir a desenvolver, a partir da sexta década de vida, uma síndrome de distúrbios da marcha, tremor e perda cognitiva, denominada síndrome de ataxia e tremor do $\underline{X}$ frágil (FXTAS) (Hagerman et al., 2001). Exames anatomo-patológicos revelaram inclusões citoplasmáticas, positivas para ubiquitina, em neurônios e astrócitos, além de gliose do SNC de pacientes FXTAS e sugeriram um mecanismo patogenético mediado pelo acúmulo do RNAm do FMR1 (Greco et al., 2006). Alelos com 40 a 60 repetições apresentam estabilidade intermediária entre alelos normais e pré-mutações, sendo denominados, por isso, alelos intermediários, sem associação clínica estabelecida (Haddad et al., 1999).

A expressão do RNAm do FMR1 foi analisada por hibridação in situ de tecidos humanos fetais, nas oitava, nona e trigésima quinta semanas gestacionais (Abitbol et al, 1993). Os fetos na oitava e nona semanas apresentavam distribuição homogênea do RNAm do FMR1 no encéfalo e medula espinhal, cartilagens, mesênquima cefálico (crânio cartilaginoso, corpos cerebrais e arcos carpais) e fígado. No SNC, a marcação foi mais intensa nas zonas intermediária marginal, periventricular cervical, embora as regiões mais superficiais também mostraram expressão. Em fetos de 25 semanas 
gestacionais, a expressão de FMR1 mostrou-se elevada na placa neocortical, nas zonas ventricular e subventricular, córtexes cerebral frontal, temporal e piriforme, as regiões CA1, CA2 e CA3 do hipocampo, o núcleo basal magnocelular e no cerebelo (camada de células de Purkinje, vérmis e córtex) (Abitbol et al, 1993).

O estudo da expressão do gene FMR1 levou, em 1993, à identificação, por RTPCR, de 12 variantes de RNA produzidas em diversos tecidos, aparentemente sem especificidade, principalmente no encéfalo e gônadas (Eichler et al, 1993; Ashley et al, 1993; Verkerk et al, 1993). Verkerk e cols (1993) mostraram que estas variantes são geradas por quatro tipos de splicing alternativo do transcrito primário deste gene. Em sua análise, Ashley e cols (1993) incluiu um quinto tipo de splicing alternativo do FMR1 no splicing alternativo do FMR1. Mais tarde, onze dessas variantes de transcrito do FMR1 foram identificadas por clonagem de cDNA de culturas primárias de neurônios humanos fetais, mostrando níveis de expressão relativamente distintos (Huang et al, 1996). Foi observado posteriormente que estas variantes, tanto em cérebro quanto em outros tecidos poderiam ter níveis de expressão distintos durante o desenvolvimento. Estes e outros estudos baseados em averiguação de RNA ajudaram a definir a organização genômica do gene $F M R 1$, identificando o éxon 12, até então não descrito, e os sítios receptores alternativos de splicing nos éxons 15 e 17. Dos 17 éxons do gene FMR1, aqueles envolvidos em eventos de splicing alternativo concentram-se na porção 3' do gene e possuem os sítios de splicing com sequências mais distantes dos consensos (Eichler et al, 1993). Entre estes, os éxons 12 e 14 são do tipo cassete, enquanto os éxon 15 e 17 possuem três e dois sítios receptores de splicing, respectivamente, alterando a extensão de sua sequência transcrita incluída (Fig. 5a). A combinação destes eventos gera 24 variantes possíveis de RNA que podem dar origem a 20 isoformas não redundantes da proteína do retardo mental do X frágil (FMRP) codificada pelo FMR1 (Tabela 2, Sittler et al, 1996). 

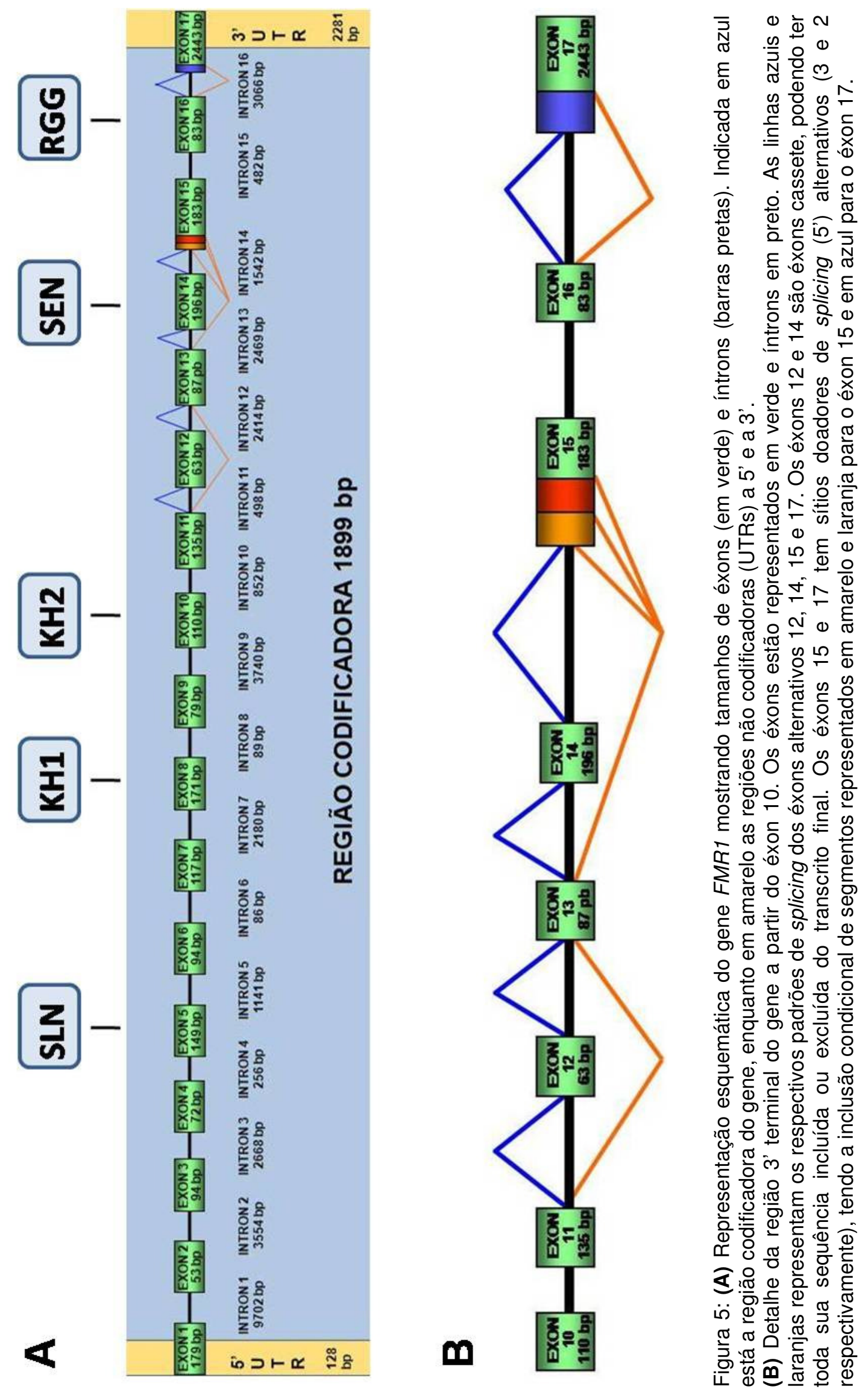


\begin{tabular}{|c|c|c|c|c|}
\hline $\mathbf{a}$ & ISO $1(71,1)$ & ISO $7(68,9)$ & ISO $13(69,1)$ & ISO $17(66,9)$ \\
\hline b & ISO $2(69,9)$ & ISO $8(67,7)$ & ISO $14(67,9)$ & ISO $18(65,7)$ \\
\hline C & ISO $3(68,4)$ & ISO $9(66,2)$ & ISO $15(66,4)$ & ISO $19(64,2)$ \\
\hline 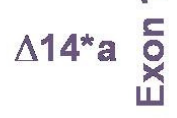 & ISO $4(50,9)$ & $\operatorname{ISO} 10(48,7)$ & $(1804)$ & $(18010)$ \\
\hline$\Delta 14^{*} \mathrm{~b}$ & $1805(49,5)$ & $\operatorname{ISO} 11(47,3)$ & $(1805)$ & $(18011)$ \\
\hline$\triangle 14^{*} \mathrm{C}$ & ISO $6(61,0)$ & ISO $12(58,8)$ & ISO $16(59,0)$ & ISO $20(56,8)$ \\
\hline
\end{tabular}

Tabela 2: Tabela exibindo as isoformas da FMRP esperadas pela tradução das variantes de transcrito do FMR1 com ou sem $(\Delta)$ os éxons 12 e 14, com uso do primeiro ou segundo sítio receptor de splicing do éxon 17 ou um dos três sítios receptores de splicing do éxon 15 ( $a$, b e c). Encontram-se entre parênteses a massa molecular (KiloDaltons, KDa) estimada para cada isoforma. Com a exclusão do éxon 14 a nova região potencialmente formada para as isoformas 4, 5, 10 e 11 apresenta um códon de parada na tradução antes do éxon 17. Desta forma, os transcritos gerados pelo uso do primeiro ou segundo sítio receptor de splicing do éxon $17 \mathrm{criam}$ isoformas redundantes. As isoformas estão identificadas por cores em 5 grupos, determinados pela proximidade da massas moleculares calculadas para cada isoforma. Fonte: Sitler et al, 1996. 
A FMRP tem 632 resíduos de aminoácidos e 71,1 kDa em sua isoforma maior, é parte de uma família protéica com as proteínas FXR1P e FXR2P, codificadas respectivamente pelos genes autossômicos, 1 e 2, relacionados ao X Frágil, FXR1 e FXR2. Os três membros desta família possuem grande similaridade de sequência entre si, cerca de 55\%, codificam para proteínas com domínios funcionais principais, compartilhados, que interagem entre si no núcleo e no citoplasma, como hetero- ou homodímeros (Zhang et al, 1995; Kirkpatrick et al, 2001). Estes domínios protéicos são responsáveis pela interação da FMRP com outros elementos protéicos e ribonucléicos, definindo suas funções no SNC.

\begin{tabular}{|l|l|l|l|l|l|l|l|l|l|l|l|l|l|l|l|l|}
\hline 1 & 2 & 3 & 4 & 5 & 6 & 7 & 8 & 9 & 10 & 11 & 12 & 13 & 14 & 15 & 16 & 17 \\
\hline
\end{tabular}

FMR1

\begin{tabular}{|l|l|l|l|l|l|l|l|l|}
\hline 1 & 2 & 3 & 4 & 5 & 6 & 7 & 8 & 9 \\
\hline
\end{tabular}

\begin{tabular}{|l|l|l|l|}
\hline 13 & 14 & 15 & 16 \\
\hline
\end{tabular}

FXR1

$86 \%$

\begin{tabular}{|l|l|l|l|l|l|l|l|l|}
\hline 1 & 2 & 3 & 4 & 5 & 6 & 7 & 8 & 9 \\
\hline
\end{tabular}

\begin{tabular}{|l|l|l|l|}
\hline 13 & 14 & 15 & 16 \\
\hline
\end{tabular}

FXR2

$70 \%$

$55 \%$

Figura 6: Alinhamento das proteínas da família da FMRP. A FMRP possúi respectivamente $86 \%$ e $70 \%$ de similaridade na região compartilhada com as outras integrantes da família, FXR1 e FXR2. Estas não possuem a sequência codificada pelos éxons 10 a 12 e 17 do FMR1. 
A proteína FMRP faz parte de um complexo ribonucleoprotéico e liga-se, de maneira seletiva, a estruturas de quartetos de guanina, quartetos $G$, de RNA. A FMRP apresenta sinais de importação (codificado pelo éxon 5) e de exportação nuclear (codificado pelo éxon 14), três domínios de ligação ao RNA, sendo dois do tipo KH (h彑mólogo à ribonucleoproteína heterogênea nuclear, hnRNP $\underline{K}$, codificados pelos éxons 8, 9 e 13) e, o terceiro, um domínio arginina-glicina-glicina (RGG, codificado pelo éxon 16), além de dois domínios agenet (codificados pelos éxons 3 e 4) (Bardoni et al., 1997; Feng et al., 1997; Darnell et al., 2001; Maurer-Stroh et al., 2003). O segmento codificado pelos éxons 10 a 12 do FMR1 está ausente nas proteínas FXR1 e FXR2, o que sugere uma relevância funcional, diferencial para a FMRP (Fig. 6).

No SNC, a expressão da FMRP é especialmente elevada em neurônios do hipocampo, córtexes cerebral e cerebelar, relacionando-se diretamente às síndromes neurológicas, SXF e FXTAS. A partir de diversos estudos para averiguar interações protéicas e distribuição subcelular da FMRP, propôs-se que, uma vez sintetizada, ela entre no núcleo celular, onde forma complexos ribonucleoprotéicos, que deixam o núcleo e são transportados aos dendritos. Em neurônios hipocampais e corticais, a FMRP predomina nas espinhas dendríticas, que são evaginações da membrana póssináptica sujeitas a alterações morfológicas, dinâmicas, relacionadas à função sináptica e plasticidade neuronal, que são dependentes de síntese protéica (Jontes e Smith., 2000). Nas espinhas dendríticas, a FMRP deve funcionar como repressora traducional de modo relacionado à função sináptica. Cérebros de pacientes com a SXF e de camundongos nocautes do Fmr1 apresentam anormalidades das espinhas dendríticas, que se mostram mais longas, finas e densas do que o normal, sugerindo que a FMRP deva ter uma função na maturação e/ou eliminação sináptica (Comery et al., 1997; Nimchinsky et al., 2001). Esta diferença morfológica das espinhas dendríticas é significativa somente na primeira semana do desenvolvimento pós-natal, período em que a expressão do Fmr1 de camundongo é alta (Nimchinsky et al., 2001). 
Como a FMRP, o RNAm do FMR1 também se localiza nos terminais dendríticos, onde ambos se associam (Weiler et al., 1997; Greenough et al., 2001). Várias outras mensagens foram identificadas como alvo da regulação pela FMRP (Brown et al., 2001; Darnell et al., 2001). A FMRP apresenta distribuição polissomal e a grânulos de estresse, citoplasmáticos, onde ela deve inibir a tradução de RNAm, de maneira específica e seletiva ( $\mathrm{Li}$ et al., 2001). O modelo corrente tem a RNAi como a via principal de atuação da FMRP na regulação pós-transcricional da expressão gênica, uma vez que se demonstrou que esta proteína interage com componentes do complexo de silenciamento induzido pelo RNA (RISC), além de microRNAs, em Drosophila e mamíferos. Nesse modelo, a FMRP liga-se ao RNAm específico e recruta o complexo RISC e microRNAs, facilitando o reconhecimento entre microRNAs e seus alvos (Fig. 7; Jin et al., 2004). 


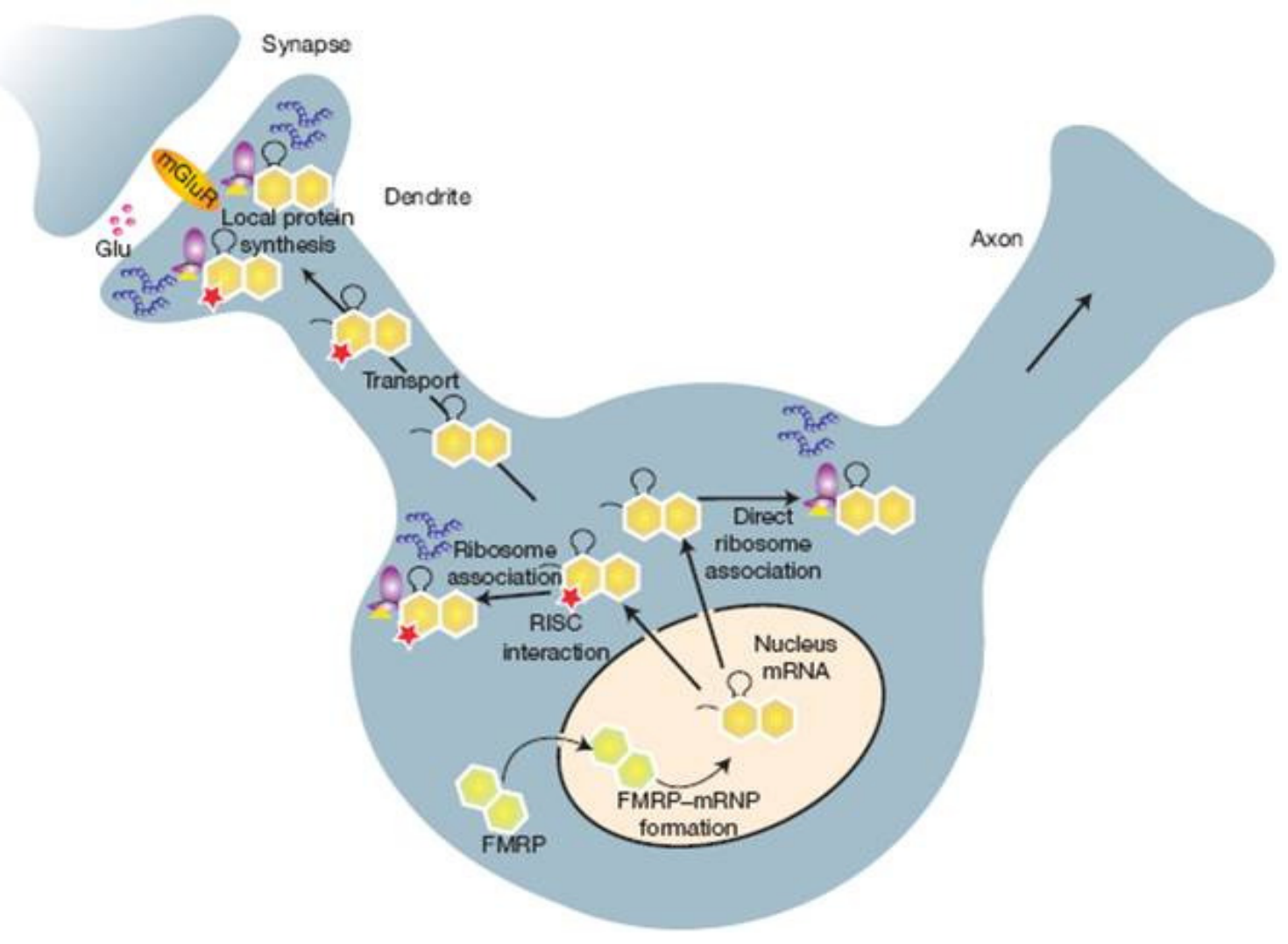

Figura 7: Modelo sintetizando as funções propostas para a proteína FMRP no neurônio. A proteína FMRP, sintetizada no citoplasma, entra no núcleo devido ao seu sinal de importação nuclear, onde interage com seus alvos de RNAm e outras proteínas. O complexo ribonucleoprotéico da FMRP sai do núcleo mediado pelo sinal de exportação nuclear da FMRP e outras proteínas. No complexo, os RNAm podem ser inativados por alterações conformacionais ou interação da FMRP com integrantes do complexo RISC. O complexo é transportado ao longo do dendrito ligado a proteínas motoras associadas ao citoesqueleto. $\mathrm{Na}$ região da sinapse do neurônio pós-sináptico, os RNAm são traduzidos mediante sinalização por neurotransmissão que inibe a FMRP por fosforilação.

Fonte: Jin et al, 2004 
A exclusão do éxon 14 dos transcritos do $F M R 1$ é um evento aparentemente raro, embora ainda não tenha sido feita uma análise semi-quantitaiva de tal expressão. Sua exclusão muda a moldura de leitura da tradução e cria possibilidade de que estas mensagens sejam degradadas. Super-expressão dos transcritos sem o éxon 14 mostram acúmulo da proteína de fusão no núcleo celular uma vez que o éxon 14 codifica para o único sinal de exportação nuclear da FMRP. Outros experimentos de super-expressão destas isoformas revelaram alteração proteômica da célula transfectada.

O encurtamento do éxon 15 do FMR1 pelo uso de sítios receptores de splicing alternativos faz com que isoformas da FMRP sintetizadas a partir desse RNAm apresentem alteração de metilação e do controle de interação com proteínas. Por outro lado, um estudo recente demonstrou que a sequência de DNA contida entre o primeiro e terceiro sítios de splicing do éxon 15 do FMR1 é transcrita em uma estrutura de RNA de quarteto G. Esta sequência constitui um acentuador exônico do splicing do éxon 15. Embora os autores não tenham comprovado por experimentos de splicing in vitro, os dados são sugestivos da existência de um ESE nessa região.

A sequência do éxon 12 do $F M R 1$ está ausente nos genes parálogos $F X R 1$ e $F X R 2$ e nos genes ortólogos de invertebrados. A exclusão do éxon 12 do $F M R 1$ não muda a moldura de leitura da tradução. Sua inclusão acrescenta 21 resíduos de aminoácidos cuja função permanece ainda obscura. Sabemos, pelo desenvolvimento em nosso laboratório de anticorpos que reconhecem especificamente este peptídio codificado pelo éxon 12 do $F M R 1$, que as isoformas que o contêm são traduzidas no SNC de rato (dados não publicados). É importante investigar se estas isoformas têm alteração funcional em relação às demais isoformas da FMRP que não expressam o éxon 12 , um projeto em desenvolvimento em nosso laboratório. Da mesma forma, é essencial analisar o padrão de expressão do éxon 12 do FMR1 no SNC e como a inclusão e exclusão deste éxon nos transcritos do FMR1 são regulados. 


\section{OBJETIVOS}

O objetivo geral deste projeto é avaliar a expressão do éxon 12 do gene Fmr1 do rato e buscar pelos elementos em cis regulatórios do seu splicing.

A definição de padrões de exclusão ou inclusão exônica dos transcritos de Fmr1 em diferentes estruturas do SNC é importante à seleção de tecidos a serem estudados experimentalmente, como na identificação de elementos em cis ou em trans regulatórios do splicing. Com o objetivo de analisar a expressão do éxon 12 do Fmr1 em córtex frontal, hipocampo e cerebelo no período embrionário e início do desenvolvimento pós-natal do rato, quando a expressão do Fmr1 é sabidamente muito alta (Verkerk et al, 1993). Amostras de cDNA destes tecidos foram obtidas de ratos no décimo nono dia embrionário (E19) e no segundo dia pós-natal (P2) e analisadas pela técnica de RT-PCR em tempo real (Real-Time RT-PCR) com iniciadores específicos para as variantes maduras que incluem o éxon 12 de Fmr1.

A exclusão do éxon 12 do Fmr1 do transcrito primário ou sua exclusão do RNAm deve depender da interação entre proteínas (elementos em trans) e seqüência transcrita (elementos em cis) de maneira regulada pela sinalização intracelular. $\mathrm{Na}$ busca por seqüências em cis candidatas à regulação do splicing do éxon 12 do Fmr1 de rato, construímos um mini-gene de seqüência genômica parcial do gene e analisamos sua expressão em células com ele transfectadas. Um padrão de inclusão e exclusão do éxon 12 foi avaliado e depois comparado ao de outros clones contendo deleções parciais feitas a partir do clone original. 


\section{MATERIAIS E MÉTODOS}

\section{Análise por RT-PCR em tempo real dos padrões de expressão das isoformas}

\section{de Fmr1:}

\section{I.I Animais e obtenção de tecidos}

Ratos Wistar foram obtidos do Centro de Bioterismo da Faculdade de Medicina da USP e sacrificados em câmaras de $\mathrm{CO}_{2}$ (protocolos aprovados pelo comitê de ética do IB-USP para projetos mais abrangentes no laboratório: 2004 e 2008). O sexo de animais no segundo dia pós-natal (P2) foi discriminado pela distância entre genitália e ânus (maior em machos) pela equipe do Centro de Bioterismo. Para os embriões, período em que a distinção da genitália é difícil, foi realizada sexagem molecular como descrito adiante. Os indivíduos machos foram separados para o estudo e as fêmeas para obtenção de DNA e de cDNA para a padronização da RT-PCR. Após sacrifício da rata prenha (décimo nono dia), os embriões foram decapitados. Ratos em P2, sacrificados, foram também decapitados. A extração do encéfalo seguiu-se incisão sagital, remoção da pele, cartilagem craniana e meninges. Os encéfalos removidos foram colocados em placas de Petri contendo $10 \mathrm{~mL}$ de PBS (solução salina tamponada com fosfato), onde foi realizada dissecção do córtex cerebral frontal, hipocampo e cerebelo. Os tecidos específicos do cérebro de cada animal, lavados em PBS, foram transferidos para criotubos individuais e congelados em nitrogênio líquido. Todas as amostras foram conservadas em freezer a $-80^{\circ} \mathrm{C}$.

\section{I.II Preparo de água DEPC estéril}

Dietilpirocarbonato (DEPC) foi adicionado à água ultrapura (1/1000). A solução foi misturada vigorosamente, incubada a $37^{\circ} \mathrm{C}$ por 16 horas, ao abrigo da luz, e autoclavada por 15 minutos. 


\section{I.III Extração de RNA total}

O RNA total foi extraído pelo método de cloreto de lítio e uréia, em que, $1 \mathrm{~mL}$ de solução de $\mathrm{LiCl} /$ réia ( $\mathrm{LiCl} 3 \mathrm{M}$ e Uréia $6 \mathrm{M})$ foi adicionado a cada criotubo contendo tecido congelado, homogeneizado em jato em seringa $(10 \mathrm{ml})$ com agulha de $8 \mathrm{~mm}$. As soluções foram mantidas a $4^{\circ} \mathrm{C}$, durante 16 horas, em microtubos $(1,5 \mathrm{~mL})$ quando foram centrifugados por uma hora a $16.000 \times \mathrm{G}$ a $4^{\circ} \mathrm{C}$. O sobrenadante foi descartado com micropipetador (para amostras de indivíduos E19 o sobrenadante foi estocado para extração de DNA genômico). Foram adicionados ao precipitado $700 \mu \mathrm{L}$ de TES (Tris $\mathrm{HCl}$ a $0,1 \mathrm{M}, \mathrm{pH} 7,4$, EDTA a $2 \mathrm{mM}$, SDS a $0,1 \%$, solução preparada com água tratada com DEPC e filtrada), a solução Foi homogeneizada com pipeta e acrescentados $700 \mu \mathrm{L}$ de fenol:clorofórmio:álcool isoamílico (25:24:1) e novamente homogeneizando. As amostras foram centrifugadas por cinco minutos a $16.000 \times \mathrm{G}$ a temperatura ambiente. A fase superior foi transferida a um novo tubo ao qual foram adicionados $700 \mu \mathrm{L}$ de fenol:clorofórmio:álcool isoamílico (25:24:1), homogeneizado e centrifugado por cinco minutos a $16.000 \times \mathrm{G}$ à temperatura ambiente. A fase superior foi transferida a um novo tubo, uma alíquota de $10 \mu \mathrm{L}$ foi retirada para controle em gel e ao restante foi adicionado igual volume de clorofórmio:álcool isoamílico (24:1), homogeneizado e centrifugado por cinco minutos a 16.000 × G a temperatura ambiente. A fase superior foi coletada e adicionou-se $10 \%$ do volume de acetato de sódio $3 \mathrm{M}, \mathrm{pH} 5,2$ e dois volumes de etanol absoluto gelado. Amostras de RNA precipitado foram estocadas $\mathrm{a}-80^{\circ} \mathrm{C}$ até serem utilizadas.

\section{I.IV Extração de DNA genômico}

O sobrenadante obtido da lise celular durante extração de RNA de tecidos de ratos em E19 foi submetido à extração de DNA genômico. A este sobrenadante foram adicionados $10 \%$ do seu volume de acetato de sódio a $3 \mathrm{M}, \mathrm{pH} 5,2$ e dois volumes de etanol absoluto gelado. Após 16 horas a $-80^{\circ} \mathrm{C}$, os tubos foram centrifugados a 16.000 x G a $4^{\circ} \mathrm{C}$ por 20 minutos e o sobrenadante foi descartado. O precipitado foi lavado em 
$250 \mu \mathrm{L}$ de etanol $80 \%$ gelado e centrifugado a $16.000 \times \mathrm{G}$ a $4^{\circ} \mathrm{C}$ durante 10 minutos. $\mathrm{O}$ sobrenadante foi descartado e os tubos secos ao ar por 30 minutos. O precipitado de DNA foi ressuspenso em $50 \mu \mathrm{L}$ de água ultrapura. Dez $\mu \mathrm{L}$ de cada amostra de DNA foram aplicados em gel de agarose a $2 \%$ para quantificação como padrão de dosagem Low Mass DNA Ladder (Invitrogen) realizando eletroforese a 100V por 15 minutos em tampão TBE $1 \mathrm{X}$ (Tris-base $89 \mathrm{mM}$, ácido bórico $89 \mathrm{mM}$, EDTA 2mM). As amostras foram coradas com brometo de etídio $(2,5 \mathrm{mM})$ e observadas à luz ultravioleta.

\section{I.V Sexagem molecular}

DNA $(1 \mu \mathrm{L})$ de cada amostra dos animais em E19 foi utilizado em reação em cadeia da polimerase (PCR) com iniciadores (TSPY-1S: 5'-ACAATCCTGGGTTGAGGATG-3'; TSPY-1A: 5'-GTGCACACAGCCAGTTGAAG-3') específicos para o gene Tspy do cromossomo $\mathrm{Y}$ de rato. A reação foi realizada em volume final de $10 \mu \mathrm{L}$ em tampão (Invitrogen, Carlsbad CA) a $1 \mathrm{X}, \mathrm{MgCl}_{2}$ a $1.5 \mathrm{mM}$ (Invitrogen, Carlsbad CA), $200 \mu \mathrm{M}$ de

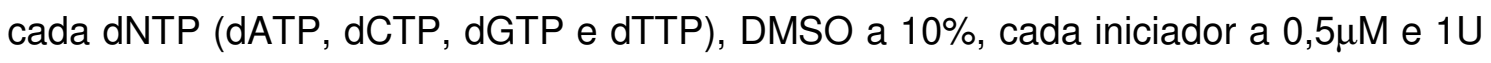
de polimerase Taq de DNA (Invitrogen, Carlsbad CA). Em termociclador, após uma desnaturação a $94^{\circ} \mathrm{C}$ por dois minutos, as amostras foram submetidas a 35 ciclos de $94^{\circ} \mathrm{C}$ por 15 segundos, $54^{\circ} \mathrm{C}$ por 30 segundos e $68^{\circ} \mathrm{C}$ por um minuto. A extensão final foi a $68^{\circ} \mathrm{C}$ por sete minutos. A observação dos produtos de PCR foi feita em gel de agarose a $2 \%$ com brometo de etídio $(2,5 \mathrm{mM})$, à luz ultravioleta, após eletroforese em tampão TBE 1X a 100V por 20 minutos. O padrão de peso molecular Low Mass DNA Ladder (Invitrogen, Carlsbad CA) foi aplicado no mesmo gel.

\section{I.VI Quantificação de RNA}

Amostras de etanol contendo RNA precipitado $(100 \mu \mathrm{L})$ foram centrifugados a $16.000 \times \mathrm{G}$ a $4^{\circ} \mathrm{C}$ durante 20 minutos. O sobrenadante foi descartado e ao precipitado foram adicionados $250 \mu \mathrm{L}$ de etanol $80 \%$ gelado. Os tubos foram centrifugados a $16.000 \times \mathrm{G}$ a $4^{\circ} \mathrm{C}$ durante dez minutos. $\mathrm{O}$ sobrenadante foi descartado e os tubos 
secos ao ar por 30 minutos. O DNA foi ressuspenso em $50 \mu \mathrm{L}$ de água tratada com DEPC. A dosagem do RNA foi realizada em gel de agarose a $0,8 \%$, aplicando $2.5,5$, e $10 \mu \mathrm{L}$ de cada amostra por canaleta. A eletroforese foi realizada em tampão TBE $1 \mathrm{X}$ aplicando corrente de 50V por 30 minutos. Brometo de etídio foi adicionado ao gel anteriormente a polimerização (1/10.000) para observação das amostras à luz ultravioleta. O padrão de tamanho molecular Low Mass DNA Ladder foi aplicado no mesmo gel para a quantificação do RNA.

\section{I.VII Síntese de cDNA}

Dois microgramas de RNA foram utilizados para a síntese de cDNA com o sistema SuperScript III First-Strand Synthesis System for RT-PCR (Invitrogen, Carlsbad CA). Volumes de etanol contendo $2 \mu \mathrm{g}$ de RNA precipitado foram centrifugados como descrito acima e o RNA ressuspenso em $23 \mu \mathrm{L}$ de $\mathrm{H}_{2} \mathrm{O}$-DEPC. Amostras foram transferidas para microtubos de microcentrífuga de $0,2 \mathrm{~mL}$, onde foram adicionados $3 \mu \mathrm{L}$ de tampão de reação DNAsel (Invitrogen, Carlsbad CA) e $4 \mu \mathrm{L}$ de DNAsel Amplification Grade (Invitrogen, Carlsbad CA). As amostras foram incubadas por 15 minutos à temperatura ambiente, a elas foram adicionados $4 \mu \mathrm{L}$ de EDTA a $25 \mathrm{mM}$ e aquecidas por dez minutos a $65^{\circ} \mathrm{C}$ para inativação da DNAsel. Foram adicionados imediatamente as amostras de RNA $3 \mu \mathrm{L}$ de oligoDT $(500 \mu \mathrm{g} / \mathrm{ml})$ e $2 \mu \mathrm{L}$ de iniciadores aleatórios $(50 \mu \mathrm{g} / \mathrm{ml})$, incubados a $70^{\circ} \mathrm{C}$ por dez minutos, para hibridação dos iniciadores, adicionados à reação $7 \mu \mathrm{L}$ de tampão de PCR $10 \mathrm{X}, 7 \mu \mathrm{L}$ de $\mathrm{MgCl}_{2}$ a $25 \mathrm{mM}$, 3.5 $\mu \mathrm{L}$ de dNTP mix a $10 \mathrm{mM}, 7 \mu \mathrm{L}$ de DTT a $0,1 \mathrm{M}$ e $4.5 \mu \mathrm{L}$ de água DEPC. As amostras foram centrifugadas e recolocadas rapidamente no termociclador a $42^{\circ} \mathrm{C}$ por cinco minutos. Foram adicionados $2 \mu \mathrm{L}$ da transcriptase reversa SuperScript III seguidos de incubação a $42^{\circ} \mathrm{C}$ por 50 minutos em termociclador. As amostras foram aquecidas a $70^{\circ} \mathrm{C}$ por 15 minutos e adicionados $2 \mu \mathrm{L}$ de RNAse $\mathrm{H}$, seguido de incubação a $37^{\circ} \mathrm{C}$, por 20 minutos. As amostras de cDNA foram estocadas a $-20^{\circ} \mathrm{C}$. 


\section{I.VIII Teste dos cDNAs}

Para testar o cDNA sintetizado foram realizadas reações RT-PCR (PCR após reação com a transcriptase reversa). A primeira reação utilizou iniciadores (RACT-1S: 5'-GTCAGAAGGACTCCTACG-3'; RACT-1A: 5'-CTTCATGGTGCTAGGAGC-3') específicos para o gene da actina beta de rato. A segunda reação utilizou iniciadores (FRAX-4S: $\quad$ 5'-ACAAAGGAAAACACCCATTTT-3'; FRAX-4A: 5'TGGTTGCAGCCCATCTACGC-3') que hibridam respectivamente nos éxons 11 e 17 do gene Fmr1 de rato. As reações foram realizadas em volume total de $10 \mu \mathrm{L}$ contendo tampão Taq (Invitrogen, Carlsbad CA) a 1X, $\mathrm{MgCl}_{2}$ a 1.5mM (Invitrogen, Carlsbad CA), $200 \mu \mathrm{M}$ de dATP, dTTP, dCTP e dGTP, DMSO a 10\%, cada um dos iniciadores a $0.1 \mu \mathrm{M}$ e $0.5 \mathrm{U}$ de polimerase Taq de DNA (Invitrogen, Carlsbad CA). Em termociclador, após uma desnaturação a $94^{\circ} \mathrm{C}$ por dois minutos, as amostras foram submetidas a 35 ciclos de $94^{\circ} \mathrm{C}$ por 15 segundos, $52^{\circ} \mathrm{C}$ por 30 segundos e $68^{\circ} \mathrm{C}$ por um minuto. A extensão final foi realizada a $68^{\circ} \mathrm{C}$ por sete minutos. A observação dos produtos foi feita em gel de agarose a $2 \%$ corado com brometo de etídio $(2,5 \mathrm{mM})$ e observadas à luz ultravioleta após eletroforese em tampão TBE 1X, a 100V, por 15 minutos. O Padrão de peso molecular O' GeneRuler 1Kb DNA Ladder Plus (Fermentas) foi aplicado no mesmo gel.

\section{I.IX Reação de PCR em tempo real}

Para a reação de PCR em tempo real, os iniciadores de oligonucleotídeos foram desenhados utilizando-se o software Primer 3 (http://www-genome.wi.mit.edu/cgibin/primer/ primer3_www), sua especificidade verificada através do BLAST (http://www.ncbi.nlm.nih.gov /BLAST), e sintetizados pela IDT (Coralville IA). Os oligonucleotídeos FRAX-13S (5'-AGTTGTGAGGGTGAGGATCG-3'), FRAX-12A (5'TTGGAAGGTAGGGAACTTGG-3') e FRAX-13A (5'ACAATTGATGAAACCACTAACACC-3') hibridam respectivamente no éxons 10, 11 e 
12 do Fmr1. Os iniciadores foram diluídos a $2 \mathrm{mM}$ e testados em reações de amplificação (PCR) qualitativas, como descrito acima.

A análise da expressão gênica foi feita através da PCR quantitativa em tempo real (qPCR) no Instituto do Coração, InCor, FM-USP, com colaboração da Dra. Silvana Chiavegatto. As reações de qPCR foram feitas no equipamento Rotor Gene 3000 (Corbett Research, Concord, Austrália). O qPCR determina o Ct para cada amostra, ou seja, o ciclo de amplificação em que o acúmulo de fluorescência na amostra atinge a linha de detecção arbitrária (threshold). O resultado é coletado durante a fase exponencial de amplificação, que ocorre quando a emissão de fluorescência é proporcional ao número inicial de cópias do produto amplificado, ou concentração da amostra. Os oligonucleotídeos sense e antisense específicos para cada um dos genes candidatos a controle interno (genes com expressão similar entre os tratamentos) foram cedidos pela Dra. Silvana Chiavegatto. Foram testados três genes para controle interno, Ppia (ciclofilina), Gapdh (gliceraldeído 3-fosfato desidrogenase) e Actb (betaactina), amplificados respectivamente com os iniciadores, Ppiar-1S (5'AATGCTGGACCAAACACAAA-3') e Ppiar-1A (5'- CCTTCTTTCACCTTCCCAAA-3'), Gapdhr-1S (5'-AGGAGCGAGACCCCACTAAC-3') Gapdhr-1A (5'GTGGTTCACACCCATCACAA-3') e Actbr-1S (5'-GTGGGAATGGGTCAGAAGG-3') e Actbr-1A (5'-GGTCATCTTTTCACGGTTGG-3'). As reações continham 200nM de iniciadores, sais, desoxinucleotídeos, a polimerase AmpliTaq Gold de DNA, o composto fluorescente Sybr Green I e a referência passiva, o corante fluorescente ROX (Applied Biosystems), otimizados para um volume final de $20 \mu \mathrm{l}$. Para a escolha da concentração ideal do cDNA obtido das amostras a ser amplificado, foram feitas cinco diluições seriadas, $50 \mathrm{ng} / \mu \mathrm{L}, 25 \mathrm{ng} / \mu \mathrm{L}, 12.5 \mathrm{ng} / \mu \mathrm{L}, 6.25 \mathrm{ng} / \mu \mathrm{L}$ e $3.125 \mathrm{ng} / \mu \mathrm{L}$. Após a análise da curva-padrão de amplificação com as diluições para cada par de iniciadores, escolheu-se a concentração de $12,5 \mathrm{ng} / \mu \mathrm{L}$, aquela com maior eficiência para a concentração de trabalho. As reações foram incubadas a $95^{\circ} \mathrm{C}$, por 10 minutos, 
para a ativação da polimerase AmpliTaq Gold de DNA, seguido por 45 ciclos de 15 segundos a 95ㄷ $\mathrm{C}$ para desnaturação, 60 segundos a $60^{\circ} \mathrm{C}$ para hibridação, extensão e coleta do sinal de fluorescência. Para cada corrida tivemos o controle negativos NTC (ausência do DNA) e o cDNA de cada amostra referente ao grupo controle e experimental amplificadas em triplicatas. Após o término de cada corrida, a especificidade do produto de PCR formado foi determinada através de um ciclo de dissociação (95ํㅡ por 15 segundos, estabilização a $60^{\circ} \mathrm{C}$, seguido de aumento gradual de temperatura de $2^{\circ} \mathrm{C}$ por minuto). Assim, somente foram utilizados os primers cujos produtos amplificados mostraram pico único, claro e bem definido à temperatura correta. O software RG-6000 (Corbett Research, Concord, Austrália) foi usado para gerar a curva-padrão de cada produto de amplificação, as curvas de dissociação e as planilhas contendo os dados brutos de fluorescência através dos quais foram calculados os valores de Ct para todas as amostras amplificadas com cada par de oligonucleotídeos. Para cada estrutura cerebral e idade, a quantidade de transcrito, referente ao RNAm, de cada amplicom foi determinada a partir do Ct da amostra em análises diretas ou através da normalização dos resultados brutos pela expressão de genes que não se alteraram nessas regiões. Para cada região cerebral foram testados genes de referência: Ppia (ciclofilina), Gapdh (gliceraldeído 3-fosfato desidrogenase) e Actb (b-actina). Utilizou-se o aplet geNorm (Vandesompele et al., 2002), que através de comparações pareadas sugere os genes mais estáveis em cada amostra. Através da análise dos resultados gerados por este software e pela observação das amplificações de padronização, foi determinado que o gene da ciclofilina é o mais indicado para a normalização dos resultados de expressão.

A quantidade de transcrito em cada amostra foi determinada, relativamente, baseada no $\mathrm{Ct}$ de cada amostra normalizado pelo seu $\mathrm{Ct}$ na reação com os oligos específicos para o gene controle. As relações matemáticas utilizadas foram aplicadas por meio de matrix modificada cedida pela Dra. Silvana Chiavegatto. 


\section{Análises in silico para busca de elementos regulatórios:}

Análises in silico nas seqüências genômicas do Fmr1, na região do início do íntron 11 ao final do íntron 12, foram realizadas para identificar segmentos candidatos a reguladores do splicing do éxon 12. Foram utilizadas ferramentas de bioinformática virtuais disponíveis na rede (ESE Finder - Release 3.0: http://rulai.cshl.edu/cgibin/tools/ESE3/esefinder.cgi?process=home;

Acescan2: http://genes.mit.edu/acescan2/index.html; ESR

Search: http://ast.bioinfo.tau.ac.il/ESR.htm; ASD - Alternative Splicing: http://www.ebi.ac.uk/asd-srv/wb.cgi?method=7) que utilizam algoritmos para busca de elementos na seqüência submetida que possuem a maior probabilidade de atuar como reguladores em cis do splicing. Estas ferramentas utilizam métodos de busca e bancos de dados contendo elementos regulatórios publicados por diferentes grupos de pesquisa (ESE Finder - Release 3.0: Smith et al, 2006; Cartegni et al, 2003; Acescan2: Wang et al, 2004; Yeo et al, 2004; ESR Search: Goren et al, 2006; Fairbrother et al, 2002; Zhang \& Chasin, 2004; Wang et al, 2004; EBI-ASD Alternative Splicing: Stamm et al, 2006; Thanaraj et al, 2004). Utilizando os parâmetros originais de cada programa, foram realizadas buscas específicas utilizando as seqüências dos íntrons 11 e 12 e do éxon 12 do FMR1 humano, de camundongo e de rato. As buscas foram realizadas em cada ferramenta de acordo com os bancos de dados disponíveis em cada uma. Para as ferramentas ESE Finder e ESR Search, que utilizam como referência seqüências exônicas humanas, foi submetida à seqüência humana do éxon 12. Com a ferramenta Acescan2 foram feitas buscas separadamente com as seqüências dos íntrons e do éxon 12 humanas e murinas, sempre selecionando apenas elementos da espécie correspondente. Para ASD - Alternative Splicing foram submetidas às seqüências intrônicas e exônicas das três espécies. Os resultados para esta ferramenta são apresentados listando todos os elementos identificados presentes no banco de dados que incluem todas as espécies, desta 
forma os resultados foram posteriormente triados para manter apenas elementos identificados na espécie submetida.

\section{Clonagem de segmento genômico do Fmr1: Produção de um mini-gene:}

\section{III.I Extração de DNA de leucócitos}

Três mililitros de sangue coletados de rata adulta, prenha em E19, sacrificada em câmara de $\mathrm{CO}_{2}$ foram utilizados para extração de DNA genômico. Foram adicionados ao sangue $40 \mathrm{~mL}$ de solução de lise (sacarose a $0,32 \mathrm{M}$, Tris- $\mathrm{HCl}$ a $10 \mathrm{mM}, \mathrm{pH} 7.4$, $\mathrm{MgCl}_{2}$ a $5 \mathrm{mM}$ e Triton-X-100 a 1\%) e homogeneizado a solução por inversão. Amostras foram centrifugadas por 30 minutos a $16.000 \times \mathrm{G}$ a $4^{\circ} \mathrm{C}$. O sobrenadante foi descartado e foram adicionados $4.5 \mathrm{~mL}$ de solução de $\mathrm{NaCl}$ a $0.075 \mathrm{M}$, EDTA a $0.8 \mathrm{mM}$, pH8.0) e SDS 5\%. Após homogeneização foram adicionados 50 $\mu \mathrm{L}$ de Proteinase $\mathrm{K}$ (10mg/mL) e a solução foi incubada a $42^{\circ} \mathrm{C}$ por 3 em tubo de vidro de $15 \mathrm{~mL}$, ao qual foram adicionados $5 \mathrm{~mL}$ de fenol e homogeneizado. As amostras foram centrifugadas por 20 minutos a $16.000 \times \mathrm{G}$ a $4^{\circ} \mathrm{C}$. A fase superior foi transferida para um novo tubo onde foi submetido a duas extrações com clorofórmio:álcool isoamílico (24:1), como descrito. À fase superior obtida $(\sim 5 \mathrm{~mL})$ foram adicionados $500 \mu \mathrm{L}$ de $\mathrm{KCl}$ a $2 \mathrm{M}$ e $12 \mathrm{~mL}$ de etanol absoluto gelado e homogeneizado. O DNA precipitado foi coletado com capilar de vidro e lavado em um novo tubo contendo etanol a 70\% gelado. O DNA foi transferido para um novo tubo contendo $500 \mu \mathrm{L}$ de TE, incubado a $65^{\circ} \mathrm{C}$ por 30 minutos e à temperatura ambiente por 16 horas. O DNA extraído foi quantificado por espectrofotometria calculando a absorbância da amostra a 260nm. As amostras foram conservadas a $-20^{\circ} \mathrm{C}$.

\section{III.II Amplificação do segmento genômico do éxon 11 ao éxon 12 do Fmr1}

A amplificação dos segmentos genômicos foi realizada por PCR, com iniciadores específicos para o gene Fmr1, definindo um segmento de 2849 pares de bases que 
abrange da primeira base do éxon 11 à última do éxon 13 (ECORVFRAX-11S: 5'CCAGGGATATCGGAAAATTTGCCACCAAGTTCC-3', NOTFRAX-10A: $\quad$ 5'CCAGGGCGGCCGCCTACTTTAAGTAGTTCAGGTGATAATCCAA-3’). Os iniciadores sense e antisense continham sítios de restrição (sublinhados) para as enzimas EcoRV e Notl respectivamente.

A reação foi realizada em volume total de $20 \mu \mathrm{L}$ contendo $20 \mathrm{ng}$ de DNA genômico de rato, tampão de reação a $1 \mathrm{X}$, cada iniciador a $0,5 \mu \mathrm{M}$, e $0,5 \mathrm{U}$ da polimerase Accuprime Pfx de DNA (Invitrogen, Carlsbad CA). Em termociclador, após uma desnaturação a $94^{\circ} \mathrm{C}$ por dois minutos, as amostras foram submetidas a 35 ciclos de $94^{\circ} \mathrm{C}$ por 15 segundos, $52^{\circ} \mathrm{C}$ por 30 segundos e $68^{\circ} \mathrm{C}$ por quatro minutos e 30 segundos. A extensão final foi realizada a $68^{\circ} \mathrm{C}$ por sete minutos. Dez reações independentes foram reunidas em um tubo e cinco microtubos submetidos à eletroforese em gel de agarose a $0.8 \%$ em tampão TBE $1 \mathrm{X}$ à $100 \mathrm{~V}$ por 15 minutos, corado com brometo de etídio $(0,75 \mathrm{mg} / \mathrm{mL})$ e observadas à luz ultravioleta. O Padrão de tamanho e peso molecular High Mass DNA Ladder (Invitrogen, Carlsbad CA) foi aplicado no mesmo gel.

\section{III.III Purificação do produto de PCR}

As amostras amplificadas por PCR foram purificadas com o sistema Illustra GFX (GE Healthcare) de acordo com os procedimentos recomendados pelo fabricante. Amplificações dos dois insertos $(200 \mu \mathrm{L})$ foram divididas em dois tubos $(100 \mu \mathrm{L})$, cada um purificado separadamente em uma coluna de afinidade por DNA GFX Microspin. As colunas foram eluídas no final do procedimento em $30 \mu \mathrm{L}$ de tampão de eluição aquecido. $O$ volume recuperado da purificação por coluna foi aplicado em gel de agarose de mais baixo ponto de fusão a $0,7 \%$. A solução contendo agarose diluída em tampão TBE foi incubada em banho a $60^{\circ} \mathrm{C}$ por 1 hora e o gel polimerizado por uma hora a temperatura ambiente. As amostras foram aplicadas no gel assim como o padrão de peso molecular Low Mass DNA Ladder, submetidas à eletroforese em 
tampão TBE 1X a 25V durante uma hora e a 50V por mais uma hora. O gel foi corado com brometo de etídio $(2,5 \mathrm{mM})$ e observado à luz ultravioleta. As bandas referentes aos insertos foram recortadas com lâmina de aço em transiluminador de luz ultravioleta. Fragmentos de gel contendo DNA foram transferidos para tubos de $1,5 \mathrm{~mL}$ e novamente purificados em colunas GFX Microspin, eluídas com 30 $\mu \mathrm{L}$ de tampão de eluição aquecido. As amostras coletadas foram estocadas a $-20^{\circ} \mathrm{C}$.

\section{III.IV Adição de adenosina terminal}

Reação realizada com produtos de PCR não digeridos purificados contendo 10X Taq Buffer (Invitrogen, Carlsbad CA) a 1X, dATP (Desoxitrifosfato de Adenosina) a $200 \mu \mathrm{M}$ e $0.5 \mathrm{U}$ de Taq (Invitrogen, Carlsbad CA) em volume de $10 \mu \mathrm{L}$. A reação foi incubada em banho por 15 minutos a $72^{\circ} \mathrm{C}$.

\section{III.V Clonagem com o sistema TOPO}

A clonagem do segmento genômico do Fmr1 foi feita de modo não direcional no vetor TOPO TA (PCR 2.1-TOPO) (Invitrogen, Carlsbad CA) e, posteriormente, o inserto do clone recombinante obtido foi subclonado de modo direcional no vetor pcDNA3 (Xinl, Gonzalez, Agosti, et al, 1998).

Produtos de PCR não digeridos, purificados em gel de agarose de baixo ponto de fusão após adição de adenosina terminal, foram clonados com o sistema TOPO TA com o vetor pCR2.1-TOPO. Cada produto de PCR foi clonado em reação de $6 \mu \mathrm{L}$ contendo $4 \mu \mathrm{L}$ do produto de PCR. Reações foram incubadas a $23^{\circ} \mathrm{C}$ por 30 minutos. Solução de ligação foi usada para transformar bactérias DH5a One Shotß Chemically Competent E. Coli (Invitrogen, Carlsbad CA), com incubação em gelo por 30 minutos antes do choque térmico. $50 \mu \mathrm{L}$ de cada solução foram espalhados em placas de cultura de bactéria pré-aquecidas a $37^{\circ} \mathrm{C}$ contendo meio Luria Broth (LB) (BactoTriptona 10g/L, Bacto-Yeast 5g/L e NaCl 10g/L, pH 7.0) com agar a 1\%. O restante de cada solução foi espalhado em placas separadas. As placas foram incubadas em estufa a $37^{\circ} \mathrm{C}$ por 16 horas e guardadas a $4^{\circ} \mathrm{C}$. 


\section{III.VI Triagem das colônias}

Colônias isoladas crescidas em placas com meio LB agar foram colhidas em ambiente estéril e transferidas para tubos plásticos de $15 \mathrm{~mL}$ contendo $2 \mathrm{~mL}$ de meio LB líquido com Ampicilina $(50 \mu \mathrm{g} / \mathrm{mL})$. Os tubos foram incubados sob agitação a $37^{\circ} \mathrm{C}$ por 16 horas. $1 \mu \mathrm{L}$ de cada meio contendo bactérias foi utilizado em reação de PCR de $10 \mu \mathrm{L}$ contendo tampão Taq (Invitrogen) a $1 \mathrm{X}, \mathrm{MgCl}_{2}$ a $1.5 \mathrm{mM}$ (Invitrogen), cada dNTP a $200 \mu \mathrm{M}$, DMSO a $10 \%$, cada iniciador a $0.1 \mu \mathrm{M}$ e $0.5 \mathrm{U}$ de polimerase Taq de DNA (Invitrogen, Carlsbad CA). Em termociclador, após desnaturação a $94^{\circ} \mathrm{C}$ por 10 minutos, as amostras foram submetidas a 35 ciclos de $94^{\circ} \mathrm{C}$ por 15 segundos, $52^{\circ} \mathrm{C}$ por 30 segundos e $68^{\circ} \mathrm{C}$ por 1 minuto. A extensão final foi realizada a $68^{\circ} \mathrm{C}$ por 10 minutos. Em uma das reações o volume do meio de cultura (LB) contendo bactérias foi substituído por $1 \mu \mathrm{L}$ (20ng) de DNA genômico de rato, e foi usada como controle positivo. A visualização dos produtos foi feita em gel de agarose $1.5 \%$ corado com brometo de etídio $(2,5 \mathrm{mM})$ e observados à luz ultravioleta após eletroforese com tampão TBE 1X à 100V por 15 minutos. O peso molecular Low Mass DNA Ladder aplicado juntamente com as amostras para determinação da extensão dos produtos.

Para a triagem dos clones gerados pelo sistema TOPO que contém a construção com o éxon 12 de Fmr1 foram utilizados iniciadores (ECORVFRAX-11S: 5'CCAGGGATATCGGAAATTTGCCACCAAGTTCC-3', FRAX-13A: 5' ACAATTGATGAAACCACTAACACC-3’) específicos para o inserto.

Os iniciadores utilizados para a construção contendo o segmento do éxon 12 de Fmr1 no vetor pcDNA3 foram ECORVFRAX-11S e FRAX-13A, e são específicos para o inserto. O par de iniciadores PCDNA-1S: 5'-CACTATAGGGAGACCCATGGAC-3', PCDNA-1A: 5'-CTGATCAGCGAGCTCTAGCA-3' é específico para a seqüência do vetor.

\section{III.VII Extração do plasmídio}

A extração dos plasmídios das colônias positivas para os insertos foi realizada pelo método de lise alcalina. Um mililitro do meio LB contendo colônias isoladas foi 
transferido para um tubo de $1.5 \mathrm{ml}$ que foram centrifugados por 5 minutos a $4^{\circ} \mathrm{C}$ e $16.000 \times$ G. O sobrenadante foi removido a as bactérias ressuspensas em $100 \mu \mathrm{L}$ de solução 1 (Glicose $0.05 \mathrm{M}$, EDTA $0.01 \mathrm{M}$, Tris $0.05 \mathrm{M}$ ) gelada homogeneizada em vortex. As soluções foram incubadas a temperatura ambiente por 5 minutos e adicionados $200 \mu \mathrm{L}$ de solução $2(\mathrm{NaOH} 0.2 \mathrm{M}$, SDS 1\%) a temperatura ambiente preparada no dia, que foi homogeneizada invertendo o tubo. As soluções foram incubadas em gelo por 5 minutos e foram adicionados $150 \mu \mathrm{L}$ de solução 3 (Kac 3M, Ácido acético 11.5\%) gelada, soluções homogeneizadas invertendo o tubo e incubadas em gelo por 5 minutos. Os tubos foram centrifugados por 5 minutos a $16.000 \times \mathrm{G}$ a $4^{\circ} \mathrm{C}$ e o sobrenadante foi transferido para um novo tubo ao qual foram adicionados $500 \mu \mathrm{L}$ de fenol/clorofórmio (1:1). As soluções foram vortexadas e centrifugadas por 5 minutos a $16.000 \times \mathrm{G}$ a temperatura ambiente. A fase superior foi transferida para um novo tubo ao qual foram adicionados $500 \mu \mathrm{L}$ de clorofórmio/álcool isoamílico (1:24). As soluções foram vortexadas e centrifugadas por 5 minutos a $16.000 \times \mathrm{G}$ a temperatura ambiente. A fase superior foi transferida para um novo tubo ao qual foi adicionado $1 \mathrm{~mL}$ de etanol $100 \%$ a temperatura ambiente. As amostras foram guardadas imediatamente a $-80^{\circ} \mathrm{C}$ durante 16 horas e então centrifugadas a temperatura ambiente por 20 minutos a $16.000 \times$ G. O sobrenadante foi removido e foram adicionados $100 \mu \mathrm{L}$ de etanol $70 \%$. Os tubos foram centrifugados a temperatura ambiente a $16.000 \times$ G por 5 minutos. O sobrenadante foi removido e os tubos secos ao ar por 30 minutos. As amostras foram ressuspensas em $30 \mu \mathrm{L}$ de TE e incubadas por 20 minutos a $37^{\circ} \mathrm{C}$ em banho. Foram adicionados $5 \mu \mathrm{L}$ de RNAse e as amostras foram incubadas em banho a $37^{\circ} \mathrm{C}$ por 30 minutos. Amostras foram estocadas a $20^{\circ} \mathrm{C}$.

\section{III.VIII Quantificação do plasmídio}

Um microlitro de cada plasmídio purificado foi submetido à eletroforese em gel de agarose a $0.8 \%$ juntamente com o padrão de tamanho e peso molecular High Mass 
DNA Ladder em tampão TBE $1 \mathrm{X}$ durante 40 minutos a $100 \mathrm{~V}$. As amostras foram coradas com brometo de etídio $(2,5 \mathrm{mM})$ e observadas à luz ultravioleta

\section{III.IX Digestão do plasmídio para averiguar inserto}

Dois microlitros de cada amostra de plasmídios purificados foram digeridos em volume final de $20 \mu \mathrm{L}$, tampão de reação \#3 1X, 10U de EcoRV e $15 \mathrm{U}$ de Notl. As reações foram incubadas em banho a $37^{\circ} \mathrm{C}$ por 4 horas e aplicadas em gel de agarose a $0.8 \%$ ao lado do padrão de tamanho e peso molecular High Mass DNA Ladder para eletroforese em tampão TBE $1 \mathrm{X}$ durante 45 minutos a 100V. As amostras foram coradas com brometo de etídio $(2,5 \mathrm{mM})$ e observadas à luz ultravioleta.

\section{III.X Purificação do inserto para subclonagem}

Para subclonar os vetores produzidos no sistema TOPO, colônias positivas foram submetidas a reações de extração de plasmídio por lise alcalina como descrito acima. Os plasmídios foram digeridos com as enzimas EcoRV e Notl como descrito anteriormente e submetidos à eletroforese em gel de agarose de baixo ponto de fusão a $0,7 \%$ para isolar a banda referente ao inserto, purificada pelo sistema Ilustra GFX, como já descrito.

\section{III.XI Digestão e desfosforilação do vetor de clonagem pcDNA3}

Para a clonagem do fragmento contendo o éxon 12 do Fmr1, cinco microgramas do vetor pcDNA3 foram utilizados para a reação de digestão com as enzimas de restrição EcoRV e Notl como descrito acima. Para a clonagem das construções contendo deleções, 10 microgramas do mesmo vetor foram digeridos apenas com a enzima EcoRV e em reação separada com as enzimas BstXI e Notl (NEB) em reações de $100 \mu \mathrm{L}$ contendo $10 \mu \mathrm{L}$ de NEBuffer 3 , BSA a $100 \mu \mathrm{g} / \mathrm{ml}$ e $3 \mu \mathrm{L}$ de cada enzima. As reações foram incubadas por 12 horas a $37^{\circ} \mathrm{C}$. Após purificação com Etanol, os vetores pcDNA3 digeridos foram ressuspenso em $89 \mu \mathrm{L}$ de água ultrapura, utilizados em reação de desfosforilação realizada em volume final de $100 \mu \mathrm{L}$. Estas reações foram realizadas com $1 \mu \mathrm{L}$ de Calf Intestinal Alkaline Phosphatase (CIAP) (Invitrogen) 


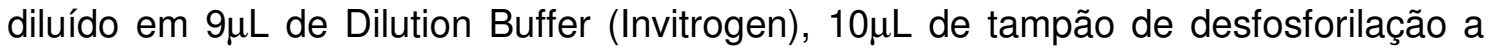
10X, incubada a $37^{\circ} \mathrm{C}$ por 30 minutos. Foi adicionado $1 \mu \mathrm{L}$ de CIAP diluído e a reação incubada a $55^{\circ} \mathrm{C}$ por 45 minutos. Foi adicionado $1 \mu \mathrm{L}$ de EDTA $0.5 \mathrm{M}$ a reação incubada a $65^{\circ} \mathrm{C}$ por 15 minutos. Adicionados $100 \mu \mathrm{L}$ de fenol/clorofórmio (1:1) às amostras homogeneizadas em vortex e centrifugadas a 16.000 x G por 5 minutos a temperatura ambiente. O sobrenadante foi coletado com pipeta e transferido para um novo tubo ao qual se adicionou $100 \mu \mathrm{L}$ de fenol:clorofórmio:álcool isoamílico (25:24:1). Amostras homogeneizadas em vórtex e centrifugadas a 16.000 x G por 5 minutos a temperatura ambiente. O sobrenadante foi coletado com pipeta e transferido para um novo tubo ao qual se adicionou $100 \mu \mathrm{L}$ de clorofórmio:álcool isoamílico (24:1). As amostras foram homogeneizadas em vórtex e centrifugadas a 16.000 x G por 5 minutos a temperatura ambiente e o sobrenadante foi coletado com pipeta e transferido para um novo tubo ao qual se adicionou $200 \mu \mathrm{L}$ de etanol $100 \%$ gelado e $10 \mu \mathrm{L}$ de acetato de sódio $3 \mathrm{M} \mathrm{pH}$ 5.2. Reações incubadas a $-20^{\circ} \mathrm{C}$ por 16 horas e centrifugadas a 16.000 x G por 20 minutos à $4^{\circ} \mathrm{C}$. O Sobrenadante foi descartado e adicionou-se $100 \mu \mathrm{L}$ de etanol $70 \%$ gelado, centrifugando a $16.000 \times \mathrm{G}$ por cinco minutos a $4^{\circ} \mathrm{C}$. O sobrenadante foi descartado e os tubos secos ao ar por 30 minutos. Amostras foram ressuspensas em $50 \mu \mathrm{L}$ de água ultrapura.

\section{III.XII Quantificação de vetor e inserto}

Dois microlitros de amostras purificadas de insertos digeridos e não digeridos e do vetor pcDNA3 foram submetidas à eletroforese em gel de agarose a 0,8\% ao lado do padrão de tamanho e massa molecular High Mass DNA Ladder. Após coloração com brometo de etídio as amostras foram observadas à luz ultravioleta sua concentração calculada pela comparação com o padrão molecular. 


\section{III.XIII Ligação}

Vetor pcDNA3 e insertos quantificados foram misturados em proporção molar de 5:1 e incubados a $65^{\circ} \mathrm{C}$ por cinco minutos. A reação de ligação ocorreu em volume final de $20 \mu \mathrm{L}$, contendo $4 \mu \mathrm{L}$ de tampão de reação da DNA Ligase a 5X (Invitrogen, Carlsbad CA) e $2 \mu \mathrm{L}$ de T4 DNA Ligase (Invitrogen, Carlsbad CA), e incubadas em banho a $42^{\circ} \mathrm{C}$ por 5 minutos e homogeneizadas em vortex. As soluções foram incubadas a temperatura ambiente por 15 minutos e então a $12^{\circ} \mathrm{C}$ por 16 horas. Solução de teste foi preparada substituindo o volume de inserto por água ultrapura.

\section{III.XIV Preparo de células competentes pelo $\mathrm{CaCl}_{2}$}

Bactérias E.Coli DH5a semeadas em uma placa de petri contendo meio LB agar sem antibiótico foram mantidas em estufa a $37^{\circ} \mathrm{C}$ por 16 horas. Colônias foram transferidas da placa para um tubo plástico de $15 \mathrm{~mL}$ contendo $10 \mathrm{~mL}$ de meio LB líquido e crescidas com agitação a $37^{\circ} \mathrm{C}$ por 16 horas. $\mathrm{O}$ volume final do tubo foi transferido para um erlenmeyer autoclavado com capacidade de 2 Litros contendo $500 \mathrm{~mL}$ de meio LB líquido sem antibiótico que foi vedado e colocado sob agitação por 4 horas. Um microlitro do meio foi utilizado para quantificação no espectrofotômetro à luz visível a 600nM usando meio LB estéril como normalizador para verificar densidade óptica (O.D.). Ao atingir a O.D. entre 0,4 e 0,6 o meio de cultura foi centrifugado em tubos plásticos de $50 \mathrm{~mL}$ a $16.000 \times \mathrm{G}$ por 15 minutos a $4^{\circ} \mathrm{C}$. O sobrenadante foi removido e todas as bactérias ressuspensas em $50 \mathrm{~mL}$ de TFBI (acetato de potássio $0.03 \mathrm{M}, \mathrm{MnCl}_{2} 0.05 \mathrm{M}, \mathrm{KCl} 0.1 \mathrm{M}, \mathrm{CaCl}_{2} 0.01 \mathrm{M}, 15 \%$ de Glicerol) filtrado gelado, em um único tubo centrifugado a $16.000 \times \mathrm{G}$ a $4^{\circ} \mathrm{C}$ por 8 minutos. $\mathrm{O}$ sobrenadante foi descartado e as bactérias ressuspensas gentilmente em $20 \mathrm{~mL}$ de TFBII (MOPS $0.02 \mathrm{M}, \mathrm{CaCl}_{2} \quad 0.075 \mathrm{M}, \mathrm{KCl} 0.01 \mathrm{M}, 15 \%$ de Glicerol) filtrado gelado. Cerca de $300 \mathrm{~mL}$ da solução de bactérias feitas competentes foram adicionados a criotubos pré-resfriados e congelados imediatamente em nitrogênio líquido e estocados $\mathrm{a}-80^{\circ} \mathrm{C}$. 


\section{III.XV Transformação bacteriana por choque térmico}

Adicionados $100 \mu \mathrm{L}$ de células $\mathrm{DH} 5 \alpha$ competentes descongeladas em gelo a reação de ligação incubando em gelo por 30 minutos. As soluções foram incubadas em banho a $37^{\circ} \mathrm{C}$ por exatos 5 minutos e recolocadas imediatamente em gelo. Volume transferido para tubos plásticos de $15 \mathrm{~mL}$ contendo $1 \mathrm{~mL}$ de meio LB e incubado em agitador por 1 hora a $37^{\circ} \mathrm{C}$. Volume transferido para tubos de microcentrífuga centrifugados por 2 minutos a $16.000 \times \mathrm{G}$ a $4^{\circ} \mathrm{C}$. O sobrenadante foi descartado e as bactérias ressuspensas em $100 \mu \mathrm{L}$ de meio LB, distribuído em placas contendo meio LB com agar a $1 \%$ e Ampicilina pré-aquecidas em estufa a $37^{\circ} \mathrm{C}$. As placas foram colocadas em estufa a $37^{\circ} \mathrm{C}$ por 16 horas e guardadas a $4^{\circ} \mathrm{C}$.

\section{III.XVI Triagem das colônias contendo o vetor pcDNA3}

A triagem das colônias contendo o inserto genômico subclonado no vetor pcDNA3 foi feita por PCR como descrito anteriormente usando os iniciadores específicos para este vetor PCDNA-1S (5'-CACTATAGGGAGACCCATGGAC-3) e PCDNA-1A (5'CTGATCAGCGAGCTCTAGCA-3') que se encontram respectivamente a 100pb a 5' e a 3' do sítio de clonagem múltipla deste vetor. As colônias consideradas positivas pela PCR foram submetidas à extração de plasmídio e digestão com as enzimas EcoRV e Notl, seguido de eletroforese, como descrito anteriormente, para a observação do inserto isolado.

\section{III.XVII Seqüenciamento do plasmídio}

O seqüenciamento das construções foi realizado a partir de produto amplificado por PCR em reação de $10 \mu \mathrm{L}$ contendo $1 \mu \mathrm{L}$ de plasmídio purificado de colônias positivas, tampão a $1 \mathrm{X}, \mathrm{MgCl}_{2}$ a $1.5 \mathrm{mM}$ (Invitrogen, Carlsbad CA), cada dNTP a $200 \mu \mathrm{M}$, DMSO a $10 \%$, cada iniciador a $0.1 \mu \mathrm{M}$ e $0.5 \mathrm{U}$ de polimerase Taq de DNA (Invitrogen, Carlsbad CA). Em termociclador, após desnaturação a $94^{\circ} \mathrm{C}$ por 2 minutos, as amostras foram submetidas a 35 ciclos de $94^{\circ} \mathrm{C}$ por 15 segundos, $52^{\circ} \mathrm{C}$ por 30 segundos e $68^{\circ} \mathrm{C}$ por 1 
minuto. A extensão final foi realizada a $68^{\circ} \mathrm{C}$ por 10 minutos. Os iniciadores utilizados foram aqueles específicos para o vetor pcDNA3 (PCDNA-1S e PCDNA-1A). O produto desta amplificação foi purificado com o sistema Illustra GFX (GE Healthcare) como descrito anteriormente. As reações de seqüenciamento foram realizadas em volume de $10 \mu \mathrm{L}$ contendo $4 \mu \mathrm{L}$ de DYEnamic ET Terminator Sequencing Premix (GE Healtcare), $2,5 \mu \mathrm{L}$ de cada iniciador a $2 \mu \mathrm{M}$ e $2 \mu \mathrm{L}$ do produto amplificado. Os iniciadores sentido (que hibridam com a fita molde do DNA) utilizados para o seqüenciamento (FRAX-18S GCGTTCAGGCTTCTGTGTTT; FRAX-19S TTCCTGCATTTGCCTTATCA; FRAX-20S TGATGTTCTTCAAATTCAGCCTA; FRAX$21 S$ CTCCTACACCTTGCCAATCA; FRAX-22S TTGAGTTTTTAGATTTGTATCCTTGG) cobrem a extensão do inserto separados $500 \mathrm{pb}$ entre si. Em termociclador, as amostras foram submetidas a 30 ciclos de $95^{\circ} \mathrm{C}$ por 20 segundos, $52^{\circ} \mathrm{C}$ por 15 segundos e $60^{\circ} \mathrm{C}$ por 1 Minuto. Após a reação de amplificação, foram adicionados aos produtos de seqüenciamento $25 \mu \mathrm{L}$ de etanol $100 \%$ gelado. As soluções foram centrifugadas a $4^{\circ} \mathrm{C}$ e $16.000 \times \mathrm{G}$ por 15 minutos. $\mathrm{O}$ sobrenadante foi descartado e $100 \mu \mathrm{L}$ de etanol $70 \%$ gelado foram adicionados. As amostras foram centrifugadas a $4^{\circ} \mathrm{C}$ e 16.000 x G por 10 minutos, o sobrenadante foi descartado e as amostras secas em estufa a $37^{\circ} \mathrm{C}$ por 6 horas. As amostras foram ressuspensas em 10 $\mu \mathrm{L}$ de Loading Solution for MegaBace (GE Healtcare) e a solução foi aplicada no seqüenciador automático Megabace 1000.

\section{III.XVIII Estoque de colônias}

$700 \mu \mathrm{L}$ de meio LB contendo células positivas para as construções foram transferidas para criotubos aos quais se adicionou $300 \mu \mathrm{L}$ de Glicerol $87 \%$. Os criotubos foram congelados imediatamente com nitrogênio líquido e estocados a $80^{\circ} \mathrm{C}$. 


\section{III.XIX Extração de plasmídios}

As construções com pcDNA3 que tiveram a presença do inserto confirmada pela digestão e seqüência sem inserção de mutações confirmada por seqüenciamento foram extraídos por reação de lise alcalina com o sistema Midiprep Kit (Qiagen). $2 \mu \mathrm{L}$ do produto purificado foram aplicados em gel de agarose a $0,8 \%$, submetido a eletroforese por 30 minutos a $100 \mathrm{~V}$, corado com brometo de etídio e observado à luz ultravioleta. O padrão de peso molecular High Mass DNA Ladder (Invitrogen, Carlsbad CA) foi usado para inferir a concentração da amostra.

\section{III.XX Produção da construção contendo deleção}

A deleção dirigida na construção contendo o éxon alternativo 12 foi realizada com enzimas de restrição a partir de desenho experimental baseado em mapas de restrição do vetor a do segmento genômico criados com a ferramenta computacional Webcutter (http://rna.lundberg.gu.se/cutter2). As enzimas utilizadas foram adquiridas da New England Biolabs (NEB) e Promega a partir de insertos purificados de colônias transformantes para as clonagens com as construções inalteradas. A variante contendo deleção foi clonada em bactérias e posteriormente transfectada em células de mamíferos seguindo os mesmos protocolos empregados para a construção original.

A construção contendo deleção foi gerada utilizando inserto contendo o éxon 12 purificado a partir de vetor pcDNA3 criado na subclonagem. O inserto foi isolado do vetor pcDNA3 por digestão dupla com as enzimas Notl e BstXI (NEB) em reação de $50 \mu \mathrm{L}$ contendo $5 \mu \mathrm{L}$ de NEBuffer 3 , BSA a $100 \mu \mathrm{g} / \mathrm{ml}$ e $4 \mu \mathrm{L}$ de cada enzima. A reação foi incubada por 12 horas a $37^{\circ} \mathrm{C}$ e purificada em gel de agarose de baixo ponto de fusão com o sistema Illustra GFX, isolando a banda de migração maior referente ao inserto. Esta construção foi utilizada para gerar a variante deletada, obtida como descrito abaixo. 


\section{Clone gFX11X130i12:}

Para a deleção, a construção foi digerida com $1 \mu \mathrm{L}$ da enzima $X m n l, 5 \mu \mathrm{L}$ de NEBuffer 2 (NEB) e BSA a $100 \mu \mathrm{g} / \mathrm{ml}$, em reação de volume final $50 \mu \mathrm{L}$. A reação foi incubada a $37^{\circ} \mathrm{C}$ por 6 horas e purificada em agarose de baixo ponto de fusão para isolar as bandas de 680pb e 2009pb que foram ligadas nas proporções molares 5:1 e 2:1, ao vetor pcDNA3.1, digerido com as enzimas BstXI e Notl como previamente descrito._Um resumo da deleção é apresentado na Figura 8 e na tabela 3.

\begin{tabular}{|c|c|c|c|}
\hline Clone & Digestão & $\begin{array}{l}\text { Purificação com } \\
\text { Low Melt }\end{array}$ & Ligação \\
\hline gFX11X13هi12 & $X m n l$ & $\begin{array}{c}\text { bandas de 680pb e } \\
2009 \mathrm{pb}\end{array}$ & $\begin{array}{c}\text { Vetor pcDNA3 digerido com } \\
\text { BstXI e Notl }\end{array}$ \\
\hline
\end{tabular}

Tabela 3: Resumo das etapas para a construção dos vetores contendo o éxon 12 de Fmr1 com diferentes deleções dirigidas. 


\section{gFX11X13வi12}

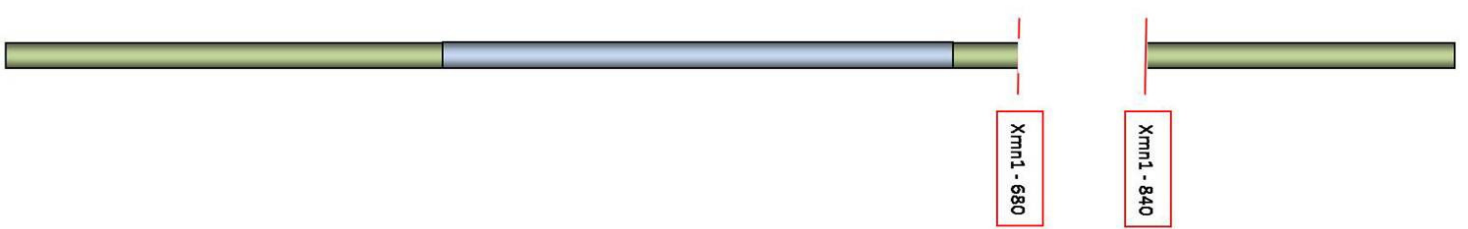

Figura 8: Representação esquemática das deleções realizadas na construção genômica contendo o éxon 12. As barras azuis representam a seqüência do éxon 12, flanqueado pelos íntrons 11 e 12 representados em verde. Os éxons 11 e 13 não estão representados.

\section{III.XXI Clonagem das construções contendo deleções}

As 4 construções contendo as deleções foram transformadas em bactérias $\mathrm{DH} 5 \alpha$ quimiocompetentes por choque térmico. As colônias resultantes foram selecionadas por PCR utilizando os iniciadores específicos para o vetor pcDNA3 (PCDNA-1S e PCDNA-1A). Os plasmídios das colônias contendo as seqüências desejadas foram extraídos das bactérias por lise alcalina (Midiprep).

\section{III.XXII Transfecção em células de rato}

Plasmídios pcDNA3 purificados contendo as construções que compreendem o éxon 12 e não recombinantes foram transfectadas em células C6 de rato. As células foram mantidas em cultura em placa de $10 \mathrm{~cm}$ com meio DMEM (FBS a $10 \%$, com ou sem $\mathrm{P} / \mathrm{S} / \mathrm{G}$ ) até cerca de 60 a $80 \%$ de confluência. Na véspera, o meio foi substituído por DMEM contendo FBS a $5 \%(P / S / G) .15 \mu g$ ou $30 \mu \mathrm{g}$ de plasmídio purificado (Midiprep) 
foram diluídos em 1,5mL de DMEM mínimo, sem soro, sem P/S/G. A solução foi misturada gentilmente e incubada a temperatura ambiente por 5 minutos. Foram acrescentados $45 \mu \mathrm{L}$ de Lipofectamine LTX (Invitrogen) e a solução foi misturada gentilmente e posteriormente incubada a temperatura ambiente por 25 minutos. $O$ meio das células foi substituído por 4,5mL de meio DMEM (FBS 10\%, P/S/G) novo. Após 25 minutos de formação dos complexos DNA-lipofectamine, foi acrescentado a

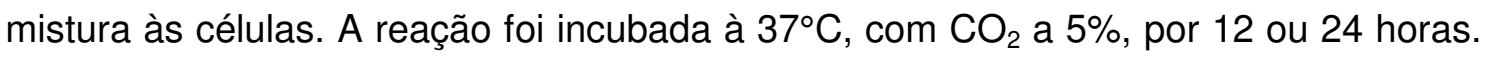
Após a incubação, as células foram lavadas duas vezes em PBS-A e raspadas com raspador estéril. Em tubos de $15 \mathrm{~mL}$ as células foram coletadas por centrifugação a 16.000 x G por 8 minutos a $4^{\circ} \mathrm{C}$, desprezando o sobrenadante.

\section{III.XXIII Análise da expressão das construções}

As células C6 transfectadas com a construções original, vetor não recombinante ou construção deletada foram prontamente submetidas a extração de RNA total por método de Cloreto de Lítio e Uréia como descrito anteriormente. O RNA extraído foi utilizado para síntese de cDNA com SuperScript III (Invitrogen) como descrito, o qual foi submetido a amplificação específica por PCR para determinar a presença de transcritos referentes a expressão dos plasmídios transfectados. A reação de PCR utilizou iniciador específico para a região do vetor pcDNA3.1 adjacente ao inserto transcrita para identificação do RNAm (FLAG) (FLAG-S: 5'TACGAGGACGATGACGATGA-3') e para a seqüência do éxon 13 (FLAG-13R: 5'GGCATTAGCGATGCTGTCTT-3'). A reação foi realizada com volume total de $10 \mu \mathrm{L}$ com tampão (Invitrogen) a $1 \mathrm{X}, \mathrm{MgCl}_{2} 1.5 \mathrm{mM}$ (Invitrogen), $200 \mu \mathrm{M}$ de cada dNTP (dATP, dCTP, dGTP e dTTP), DMSO a 10\%, cada iniciador a $0,1 \mu \mathrm{M}$ e $0,5 \mathrm{U}$ de polimerase Taq de DNA (Invitrogen, Carlsbad CA). Em termociclador, após uma desnaturação a $94^{\circ} \mathrm{C}$ por dois minutos, as amostras foram submetidas a 35 ciclos de $94^{\circ} \mathrm{C}$ por 15 segundos, $52^{\circ} \mathrm{C}$ por 30 segundos e $68^{\circ} \mathrm{C}$ por um minuto. A Extensão final foi a $68^{\circ} \mathrm{C}$ por sete minutos. A visualização dos produtos foi feita em gel de agarose 
0,8\% com brometo de etídio $(2,5 \mathrm{mM})$ observando as amostras à luz ultravioleta após eletroforese em tampão TBE $1 \mathrm{X}$ a $100 \mathrm{~V}$ por 30 minutos. O padrão de peso molecular Low Mass DNA Ladder (Invitrogen) foi aplicado juntamente com as amostras. 


\section{RESULTADOS}

\section{Estudo do padrão de expressão do éxon 12 de Fmr1:}

O éxon 12 do gene Fmr1 foi identificado em transcritos de cérebro, no entanto seu padrão de expressão ainda não é conhecido. A determinação de variações nos níveis de inclusão deste éxon em diferentes áreas do encéfalo e em diferentes etapas pode indicar processos regulados que sugerem uma função para este segmento.

\section{I.I Obtenção das amostras}

Para averiguar este padrão de expressão foram utilizados ratos Wistar machos, com 19 dias de desenvolvimento embrionário (E19) ou no segundo dia pós-natal (P2) foram sacrificados por saturação de $\mathrm{CO}_{2}$ para extração do encéfalo, a partir do qual foram dissecados hipocampo, córtex cerebral frontal e cerebelo). Foram selecionados para o estudo oito animais machos de cada idade, sendo que a sexagem dos animais em P2 foi feita à inspeção visual dos indivíduos, enquanto a dos animais em E19 por reação de PCR, devido a dificuldade na distinção da genitália externa nesta idade. Para a sexagem molecular realizada por PCR, utilizamos iniciadores específicos para o gene Tspy do cromossomo $\mathrm{Y}$ de rato, a partir de DNA extraído do encéfalo dos animais. Os animais foram diferenciados a partir da análise por eletroforese em gel de agarose dos produtos desta reação (Fig 9). Foram considerados machos, os animais cujo produto de PCR apresentou 600 pares de bases (pb). Estes animais foram selecionados para o restante do estudo. 


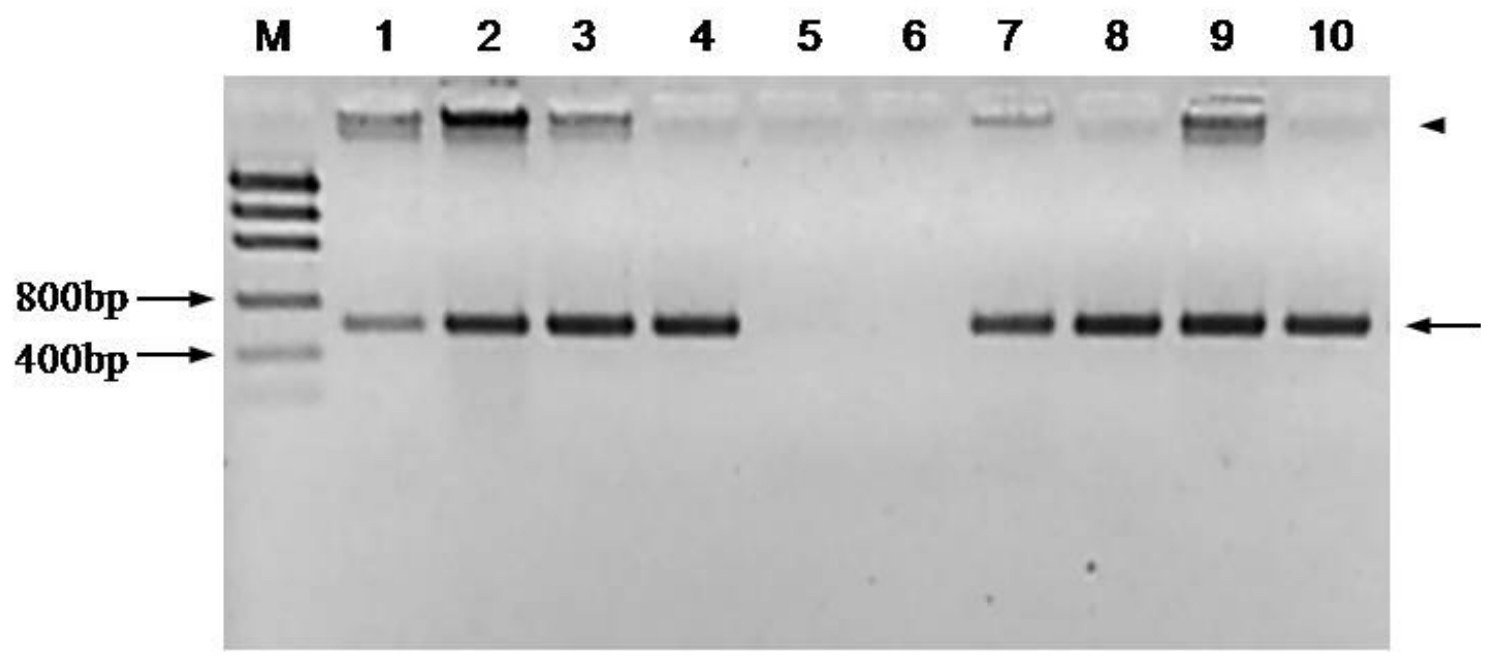

Figura 9: Gel de agarose a 2\% em que foram submetidos a eletroforese $10 \mu \mathrm{L}$ de produto de PCR amplificados com iniciadores do gene Tspy. Após eletroforese o gel foi corado com brometo de etídio.. As amostras que apresentam amplificação de um produto de $600 \mathrm{pb}$ (seta) são referentes aos indivíduos machos $(2,3,4,5,8,9,10,11)$. As bandas de migração mais lenta (ponta de seta) correspondem ao DNA genômico. O padrão de tamanho e peso molecular Low Mass DNA Ladder foi aplicado ao lado das amostras (M)

As diferentes regiões do encéfalo dos animais selecionados foram individualmente submetidas a extração de RNA total, que foi mantido precipitado em etanol a $-80^{\circ} \mathrm{C}$. Alíquotas de $100 \mu \mathrm{L}$ de etanol contendo RNA precipitado foram centrifugadas e todo 0 RNA obtido foi ressuspendido e dosado em gel de agarose, para evitar dosagem concomitante de DNA genômico. As amostras de RNA foram aplicadas no gel de agarose em três concentrações diferentes para determinar a massa de RNA por comparação com as bandas de massa conhecida do padrão High Mass DNA Ladder (Invitrogen), o que permitiu extrapolar a concentração de RNA total na solução de etanol original (Fig 10). A partir destas quantificações, volume de etanol equivalente a $2 \mu \mathrm{g}$ de RNA total foi centrifugado e ressuspendido para ser utilizado na reação de síntese de cDNA. Devido à presença, em intensidades variáveis, de DNA genômico 
nas amostras de RNA purificadas (Fig. 10), estas foram submetidas a tratamento com DNAsel, antes da reação de síntese de cDNA pelo sistema SuperScript III@ First Strand Synthesis System for RT-PCR.

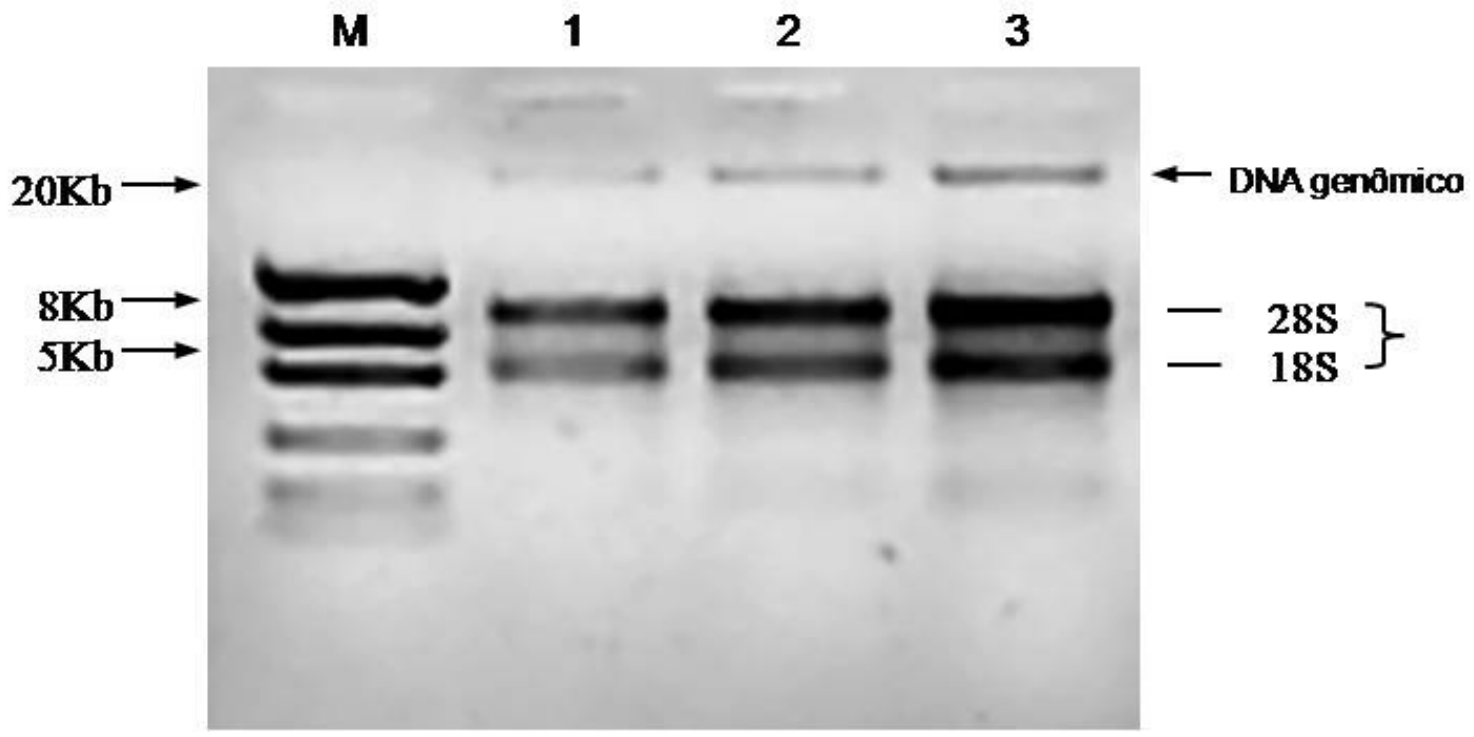

Figura 10: Exemplo de dosagem de RNA em gel de agarose 0,8\% em que foram submetidos a eletroforese $10 \mu \mathrm{L}$ de RNA total purificado a partir de córtex frontal de um animal em diferentes diluições ( 2 =diluído $4 \mathrm{X}, 3$ =diluído $2 \mathrm{X}$ e 4 =não diluído). Após eletroforese o gel foi corado com brometo de etídio. O padrão de tamanho e peso molecular High Mass DNA Ladder foi aplicado ao lado das amostas (M). As bandas de RNA (18S e 28S) estão indicadas, assim como o DNA genômico.

Após síntese do cDNA, a qualidade de cada amostra foi averiguada por PCR com iniciadores específicos para o gene da actina-beta de rato (Fig. 11 A). A presença nestas amostras de transcritos referentes ao Fmr1 foi posteriormente confirmada por PCR utilizando iniciadores específicos para região invariável deste gene (iniciadores hibridando nos éxons 10 e 11) (Fig. 11 B). Os oligonucleotídeos sintetizados 
especificamente para o estudo de expressão por PCR em tempo real hibridaram-se respectivamente nos éxons 12 e 13 do Fmr1 e foram testados em reações de PCR não quantitativo, averiguados em gel de agarose para comprovar a especificidade dos produtos amplificados (Fig $11 \mathrm{~B} \mathrm{e} \mathrm{C).}$
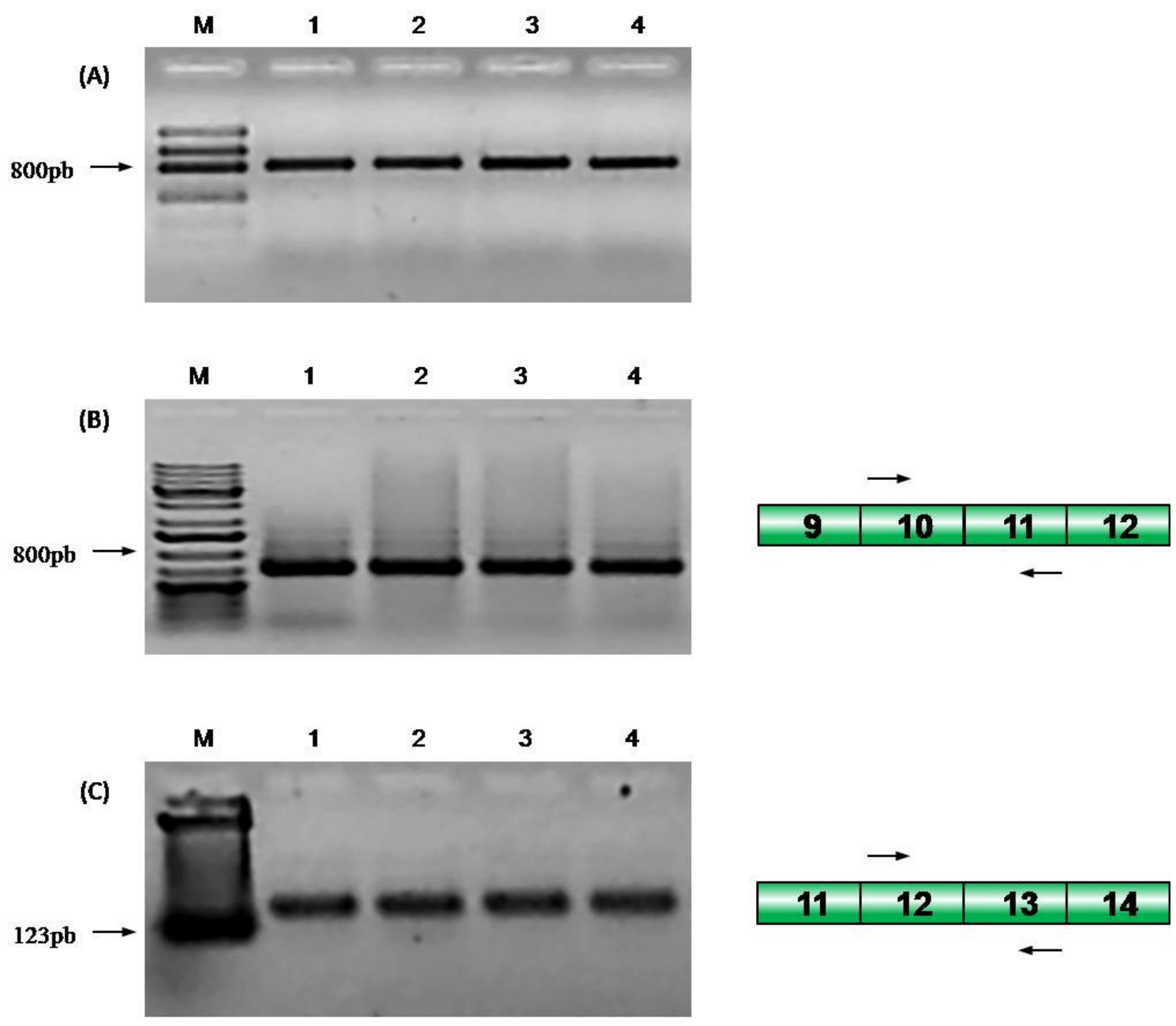

Figura 11: Exemplo de teste das amostras de cDNA em géis de agarose $0,8 \%$ nos quais foram submetidos a eletroforese amostras dos produtos de PCR realizados com iniciadores que amplificam o gene da actina beta de rato (A: 1, 2, 3 e 4); a região constante do gene Fmr1 (B: $1,2,3$ e 4) e um segmento do cDNA do Fmr1 que inclui partes dos éxons 12 e 13 (C: 1, 2, 3 e 4). As reações mostradas foram realizadas utilizando cDNA. Géis corados com brometo de etídio e observados à luz ultravioleta. Os padrões de tamanho e peso molecular Low Mass DNA Ladder (A 1), O’ Gene Ruler 1 Kb (B 1) e 123 bp Mass Ladder (C 1) foram aplicados juntamente com as amostras. Tamanhos de DNA estão indicados em pb à esquerda de cada figura. Ao lado das figuras B e C estão indicados o local de hibridação dos iniciadores (setas) em relação aos éxons do Fmr1 (blocos). 


\section{I.II Estudo da expressão por PCR em tempo real}

As amostras de cDNA das regiões encefálicas dos animais foram analisadas por PCR em tempo real em equipamento automatizado utilizando iniciadores específicos para éxons 10 e 11 do gene Fmr1 (segmento invariável), e iniciadores específicos para o éxon 12, que, com iniciadores hibridando no éxon 13, definiu um amplicom de intensidade variável. As reações com os iniciadores para a região constante foram utilizadas como controle interno, representando o nível de expressão combinado de todas as variantes de RNAm do gene Fmr1, enquanto as reações com os iniciadores específicos para o éxon 12 visavam averiguar os níveis de expressão apenas das variantes de transcrito que incluíam esta seqüência.

\section{I.II.I Expressão gênica no córtex}

A partir dos dados de expressão gerados foram criados gráficos para comparar os valores referentes aos diferentes amplicons, os quais foram submetidos a análise estatística pelo teste $t$ (de student) para comparação em pares. Para todas as amostras foram realizadas duas comparações, uma utilizando os níveis de transcrição dos amplicons referentes aos éxons invariáveis de fmr1 como referência, sem normalizador externo, e uma utilizando o gene da Ciclofilina como normalizador. Nas amostras extraídas do córtex cerebral dos animais, cujos dados não foram normalizados pela Ciclofilina (Fig 12 A), os níveis de expressão para o conjunto de variantes do Fmr1, representado por "Fmr1" apresentam grande similaridade entre as duas idades observadas. Por outro lado, os níveis de expressão referentes apenas às variantes que incluem o éxon 12, representadas por "Fmr1 E12", apresenta um aumento significativo da idade embrionária (E19) à pós-natal (P2), quando estas variantes correspondem a cerca da metade de todas aquelas expressas pelo Fmr1. Esta diferença mostrou-se significante (teste $t$ de student; 52,11 x 11,15; $\mathrm{n}=8$; $p=0,0015)$. Na análise utilizando a Ciclofilina como normalizador observou-se uma tendência, entre E19 e P2, à diminuição dos níveis dos transcritos do Fmr1 que não alcançou significância estatística (teste $t$ de student; $1,17 \times 0,88 ; n=8 ; p=0,19$ ). Nesta 
análise normalizada foi observada a mesma relação de aumento da inclusão do éxon 12 durante 0 desenvolvimento (teste $t$ de student; $0,76 \times 0,22 ; n=8, p=0,006$ ).

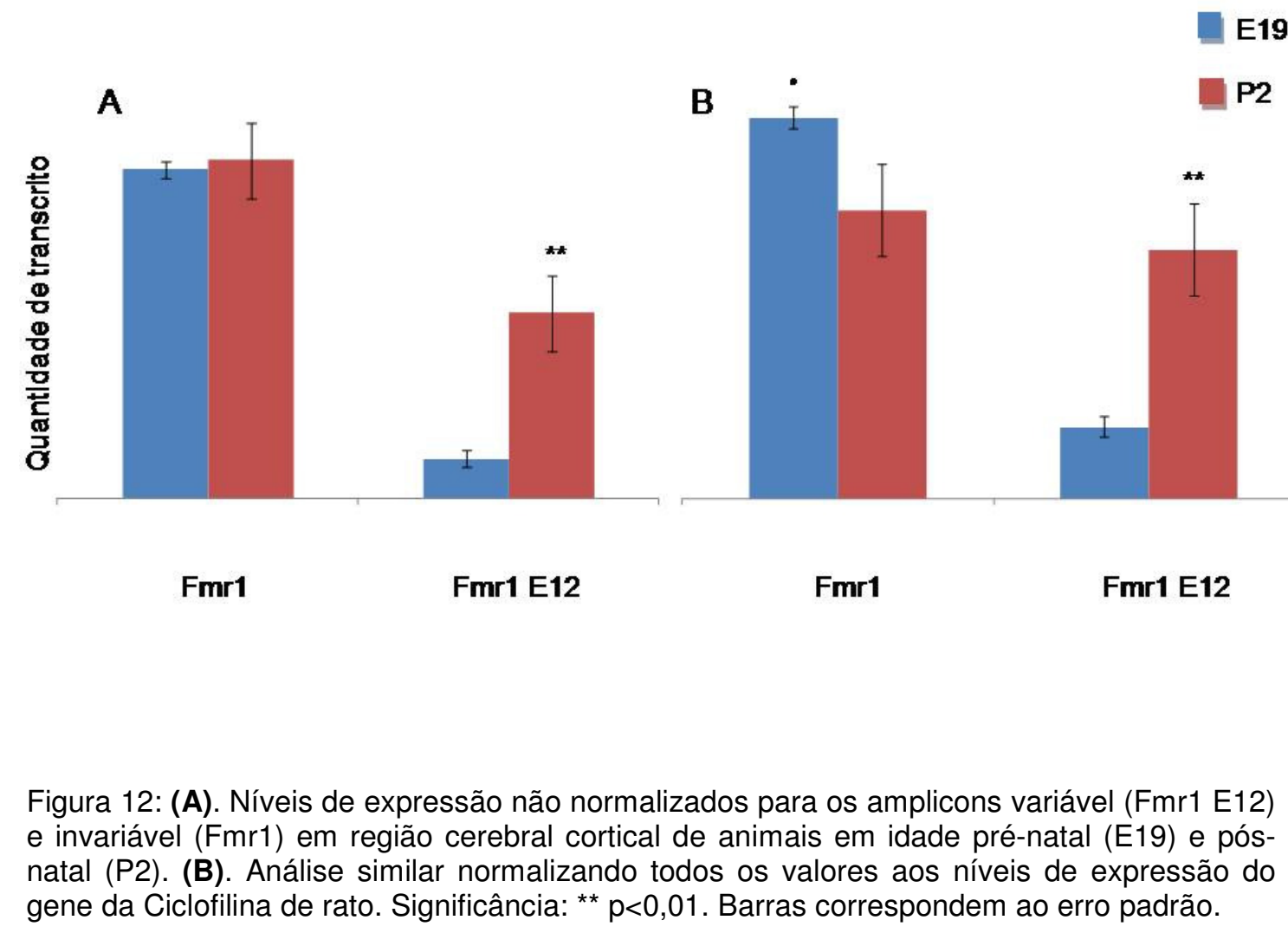

\section{I.II.II Expressão gênica no hipocampo}

A análise dos níveis de expressão do Fmr1 no hipocampo utilizando o amplicom do controle interno revelou baixa inclusão do éxon 12 nos transcritos (Fig 13). É importante observar que, no hipocampo, os animais em P2 apresentam níveis de expressão mais elevados que em E19 (teste $t$ de student; 33,7 x 134,3; $n=8$; $p=0,0035)$. Observou-se também uma tendência ao aumento da inclusão do éxon 12 nos transcritos do Fmr1, entre E19 e P2 (teste $t$ de student; $7,8 \times 19,1 ; n=8 ; p=0,06$ ). 


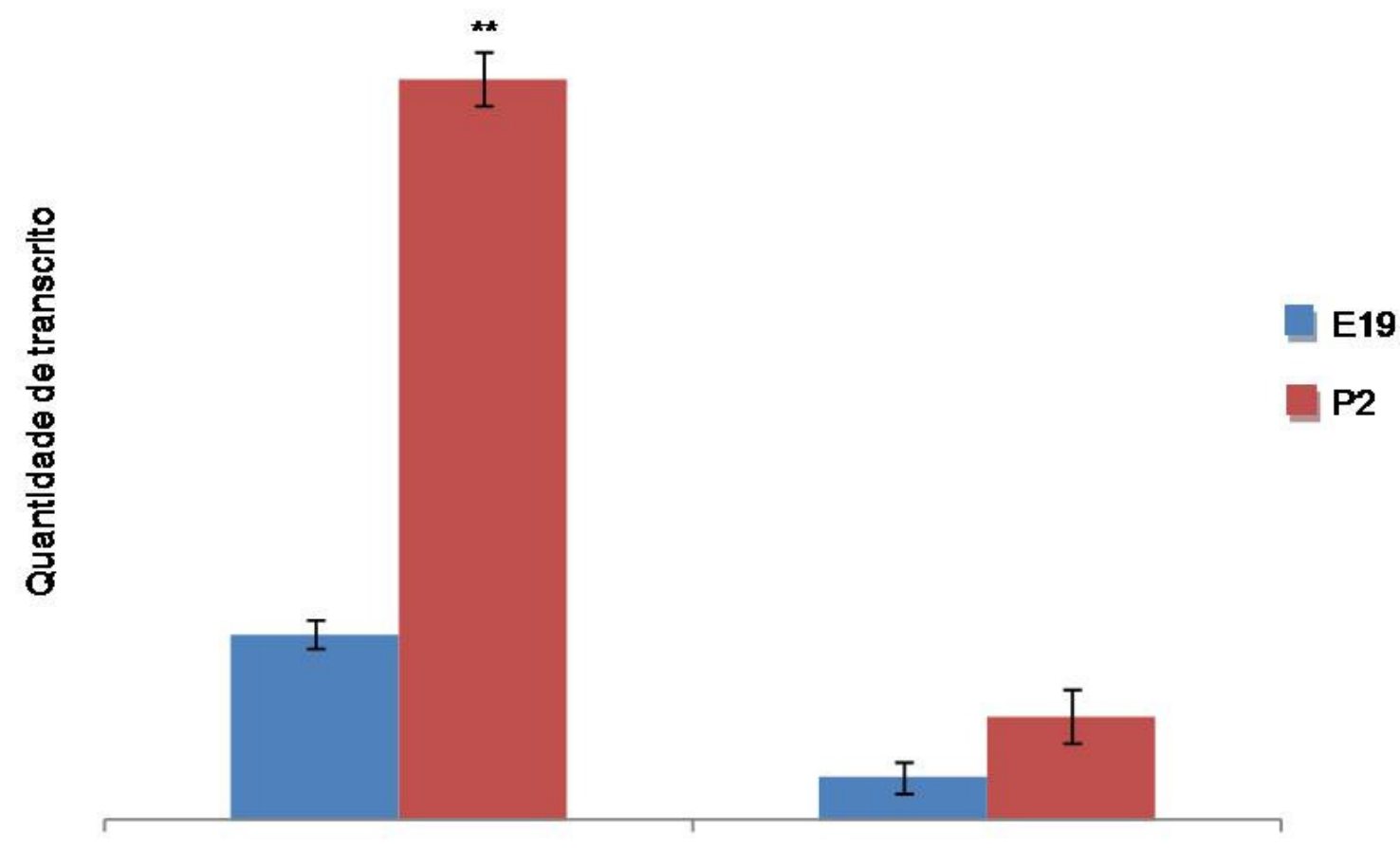

Fmr1 Fmr1 E12

Figura 13: Níveis de expressão não normalizados para os amplicons variável (Fmr1 E12) e invariável (Fmr1) em região hipocampal de animais em idade pré-natal (E19) e pós-natal (P2). Significância: ${ }^{* *} p<0,01$. Barras correspondem ao erro padrão.

Os dados referentes a expressão no hipocampo dos animais quando normalizados pela Ciclofilina foram considerados não coerentes com a análise apresentada na figura 14 e portanto não apresentados. A distorção dos dados após a normalização com este gene foi resultado do seu nível de expressão significativamente reduzido no hipocampo de animais em idade Pré-natal (E19) em relação a outras regiões e idade em que o nível de expressão foi homogêneo. 


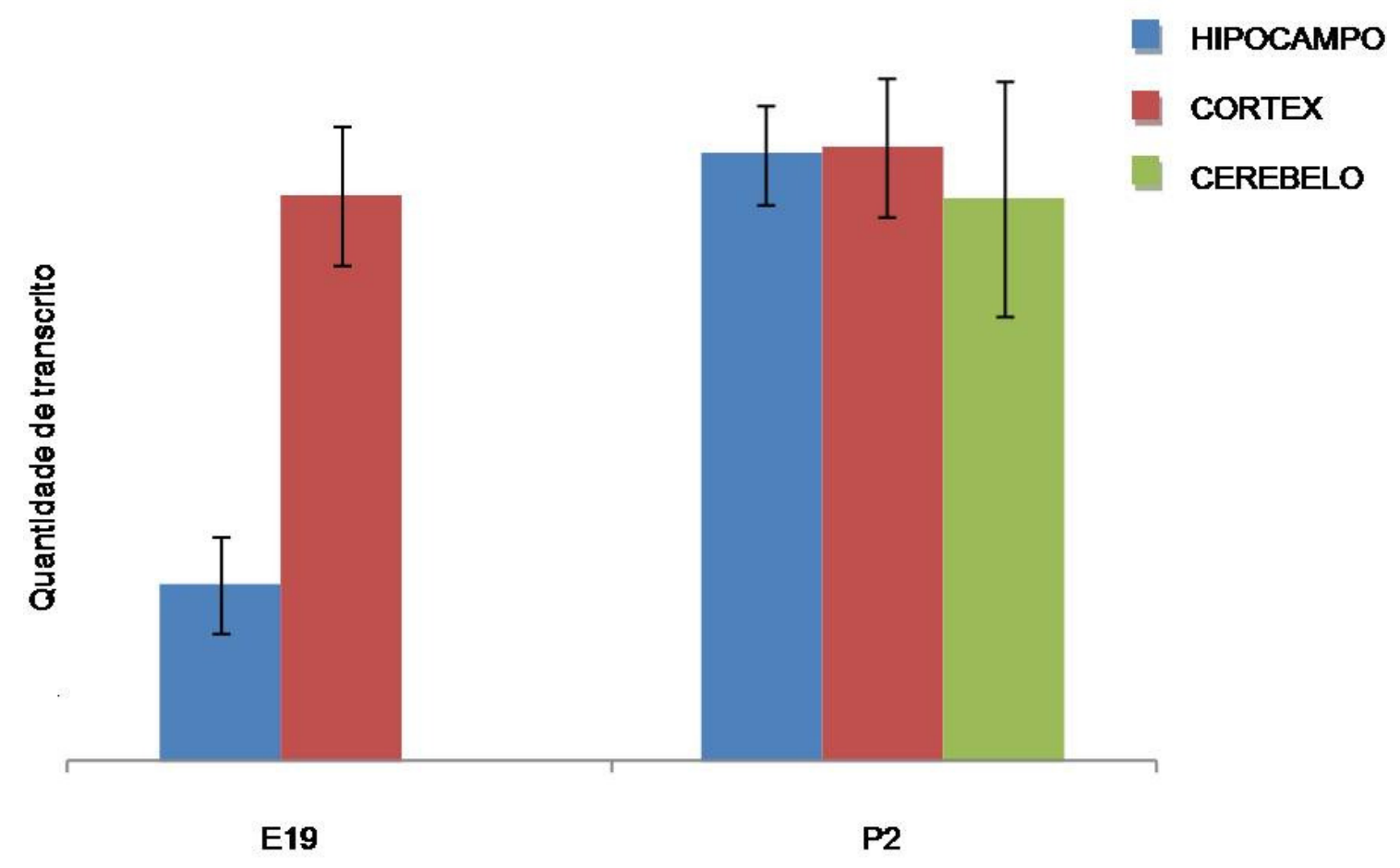

Figura 14: Níveis de expressão do gene da Ciclofilina, em E19 e P2, no hipocampo, córtex frontal e cerebelo. Barras correspondem ao erro padrão.

\section{I.II.III Expressão gênica no cerebelo}

As amostras provenientes do cerebelo de animais com dois dias de vida (P2) foram utilizadas para avaliação dos níveis gerais de expressão do Fmr1 e da inclusão do éxon 12 em seus transcritos. Não dispúnhamos de tecido cerebelar em E19. É possível observar que em P2 não há grande variação dos níveis do RNAm do Fmr1 e que há níveis razoáveis de inclusão do éxon 12 do Fmr1 que flutuam entre $20 \%$ e $50 \%$, respectivamente para as amostras não normalizadas e normalizadas (Fig 15). 


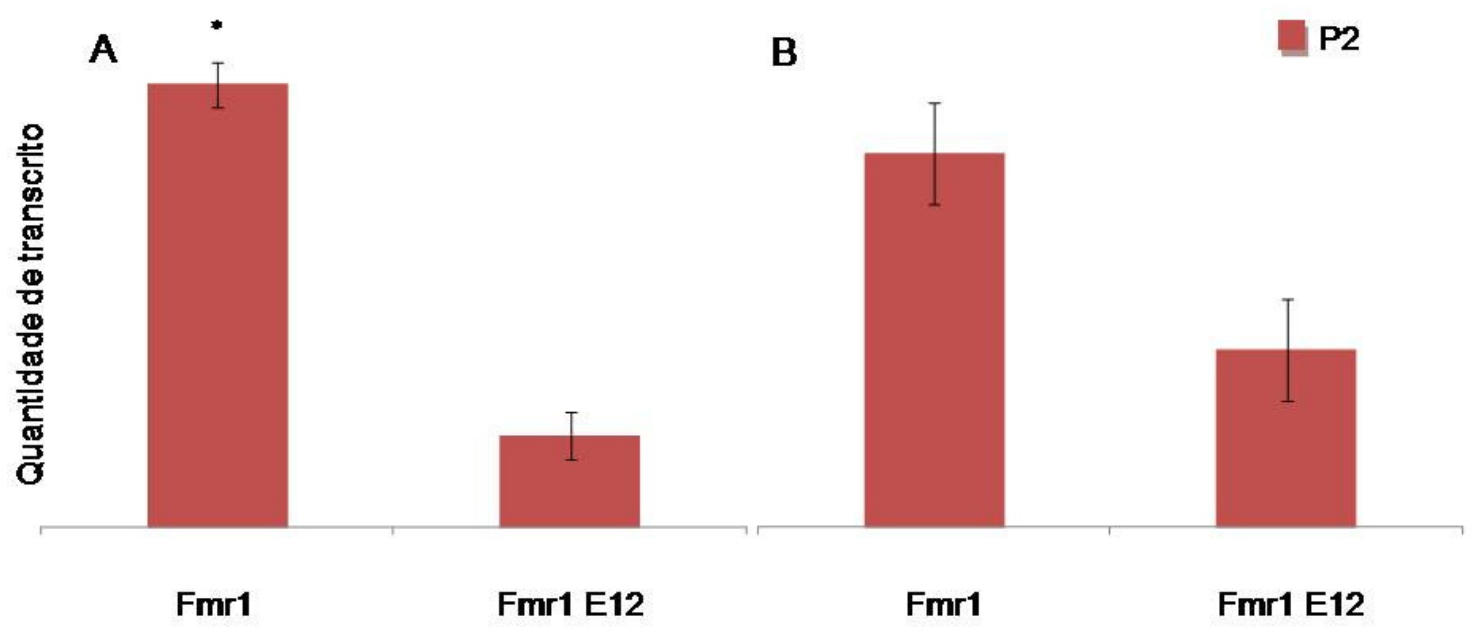

Figura 15: (A). Níveis de expressão não normalizados no cerebelo para os amplicons variável ( $F m r 1$ E12) e invariável (Fmr1) em animais no segundo dia pós-natal (P2) no cerebelo. (B). Mesma análise utilizando o gene da Ciclofilina como normalizador. Barras correspondem ao erro padrão.

\section{I.II.IV Avaliação geral do estudo da expressão do éxon 12 do Fmr1}

A razão entre os valores obtidos da expressão do amplicom variável ("Fmr1 E12") e o amplicom invariável foi calculada para cada área do encéfalo de cada animal nas duas idades. Esta representa outra forma de averiguação dos dados, em que, efetivamente, se analisa qual é a taca de inclusão do éxon 12 nos transcritos do Fmr1 e se há variação significativa entre E19 e P2. Estes dados foram sintetizados em um gráfico (Fig 16), em que estão discriminadas o percentual de inclusão do éxon 12 em relação à expressão global de Fmr1. Os dados mostram que no hipocampo, as variantes que contêm a seqüência do éxon 12 constituem no período embrionário (E19) $22 \%$ de todas as isoformas de Fmr1, valor que diminui para quase a metade após cinco dias de desenvolvimento, representando 13\% das isoformas em P2. Esta diminuição da participação das variantes que incluem o éxon 12 é estatisticamente 
significativa segundo o teste $t$ de student $(0,22 \times 0,13 ; n=8 ; p=0.016)$. Para os valores referentes às regiões corticais dos animais, uma tendência inversa pôde ser observada. No período pré-natal (E19), as variantes cerebro-corticais que incluem o éxon 12 tiveram uma participação na expressão global do Fmr1 (11\%) menor do que a observada no hipocampo (22\%), o que foi sustentado estatisticamente (teste $t$ de student; $0,22 \times 0,11 ; n=8 ; P=0.004)$. Durante o desenvolvimento, os níveis de inclusão do éxon 12 nas variantes do Fmr1 aumentou consideravelmente, fazendo com que os transcritos que contém a seqüência deste éxon correspondesse a mais da metade de todas as variantes produzidas pelo gene (57\%). Este aumento foi estatisticamente significativo pelo teste $t$ de student $(0,11 \times 0,57 ; n=8 ; p<0,0001)$, assim como foi significante a diferença de inclusão do éxon 12 em córtex em relação a hipocampo e cerebelo para a idade pós-natal (P2) (teste $t$ de student; $0,57 \times 0,13 ; n=8 ; p=<0,0001$ e $0,57 \times 0,20 ; n=8 ; p=<0,0001$ respectivamente). Para os dados do cerebelo, os níveis de participação das variantes que incluem o éxon 12 se encontram em um nível intermediário entre os do córtex e hipocampo em E19 e hipocampo em P2 (20\%). 


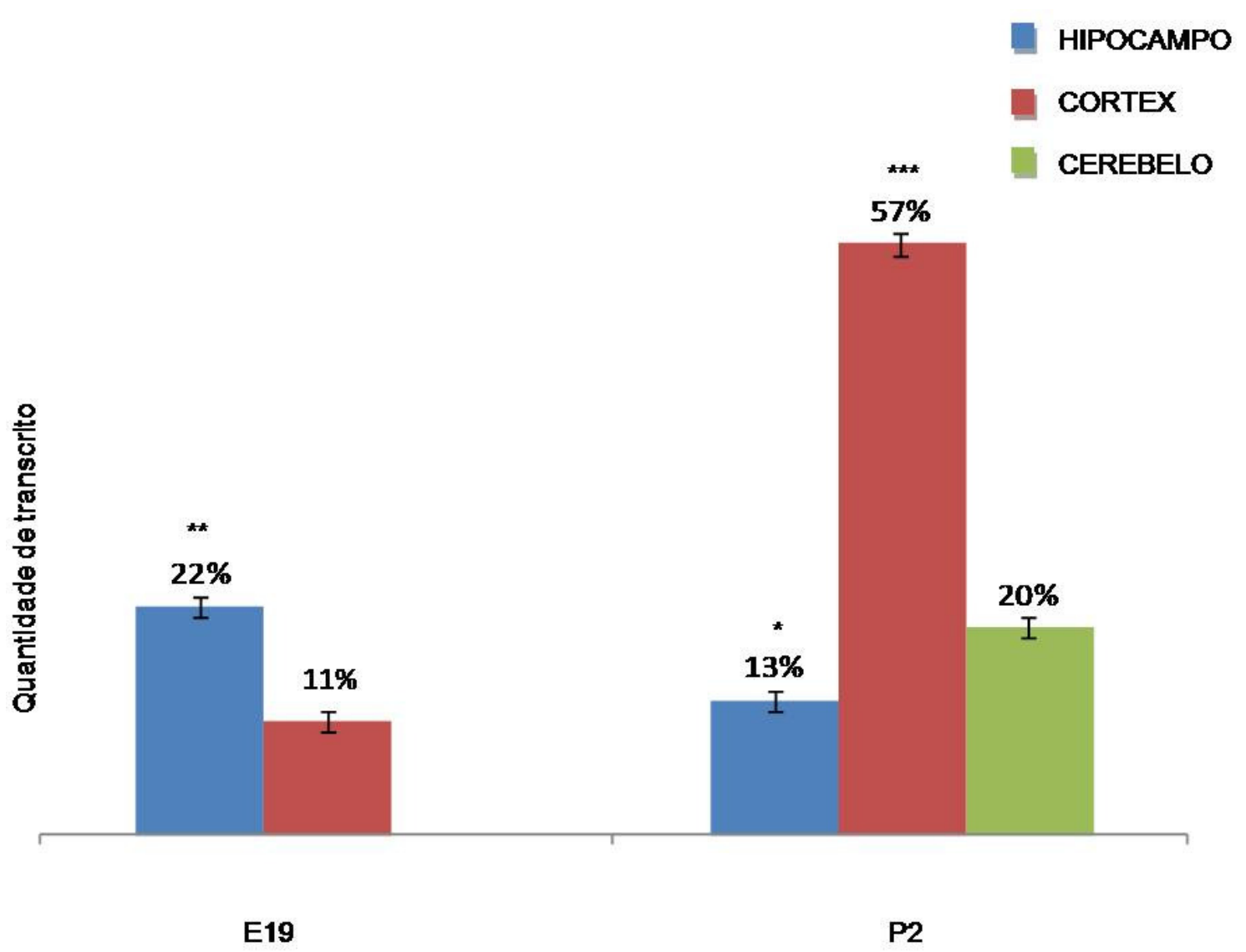

Figura 16: Gráfico mostrando para cada área do encéfalo, de cada idade, o percentual da inclusão do éxon 12 nos transcritos do Fmr1. ${ }^{*} p<0,05 ;{ }^{* *} p<0,01 ;{ }^{* * *} p<0,001$. Barras correspondem ao erro padrão.

\section{Análises in silico das seqüências genômicas do Fmr1:}

A disponibilização de bancos de dados de seqüências expressas (EST) para diversas espécies permitiu, nos últimos anos estudos globais de hibridação in silico com seqüências genômicas que identificaram um grande número de eventos de splicing. Recentemente, estudos em larga escala com microarrays utilizando sondas para junções exônicas incrementaram os bancos de dados de eventos de splicing 
conhecidos. A análise destes eventos permitiu a identificação de motivos de RNA relacionados a regulação do splicing (Blencowe, 2006). Dispõe-se atualmente de ferramentas computacionais que utilizam estes bancos de dados de motivos de regulação para várias espécies, para identificar em seqüências de DNA, segmentos exônicos e intrônicos que podem participar da regulação do splicing de éxons próximos. A identificação destes segmentos candidatos na seqüência do clone genômico do Fmr1 permite a seleção de regiões cuja deleção possui maior probabilidade de causar padrões alterados de expressão exônica em células transfectadas.

As buscas utilizaram as ferramentas Acescan2, ESE Finder 3, ESR Search e ASD Alternative Splicing e foram realizadas para a seqüência do éxon 12 do Fmr1 e para as seqüências intrônicas que o flanqueiam, sendo o íntron 11 (476pb) e os 500pb a 5' do

íntron 12. As buscas foram realizadas separadamente para ratos, camundongos e humanos, comparando as seqüências de cada espécie com o banco de dados específico para a mesma.

\section{II.I Busca por ESE e ESI no éxon 12}

Para a busca na seqüência do éxon 12 foram utilizadas as quatro ferramentas, uma vez que todas possuem bancos de dados para este tipo de seqüência. A ferramenta Acescan2 identificou no éxon 12 elementos candidatos a acentuadores e inibidores do splicing (Fig. 17). Da mesma forma, utilizando ASD - Alternative Splicing, apenas uma seqüência exônica silenciadora foi identificada (Fig. 18). Para as duas ferramentas não há identificação de quais os possíveis elementos em trans relacionados. 
A

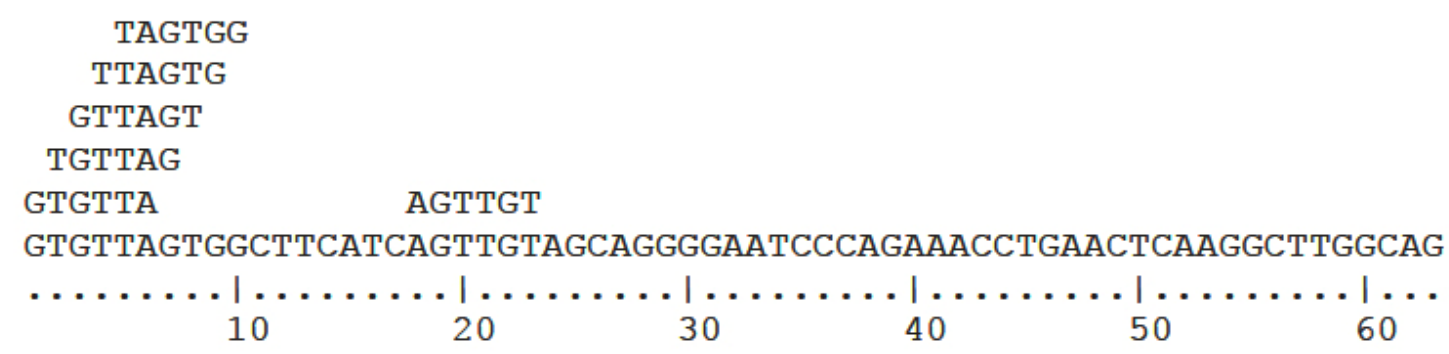

B

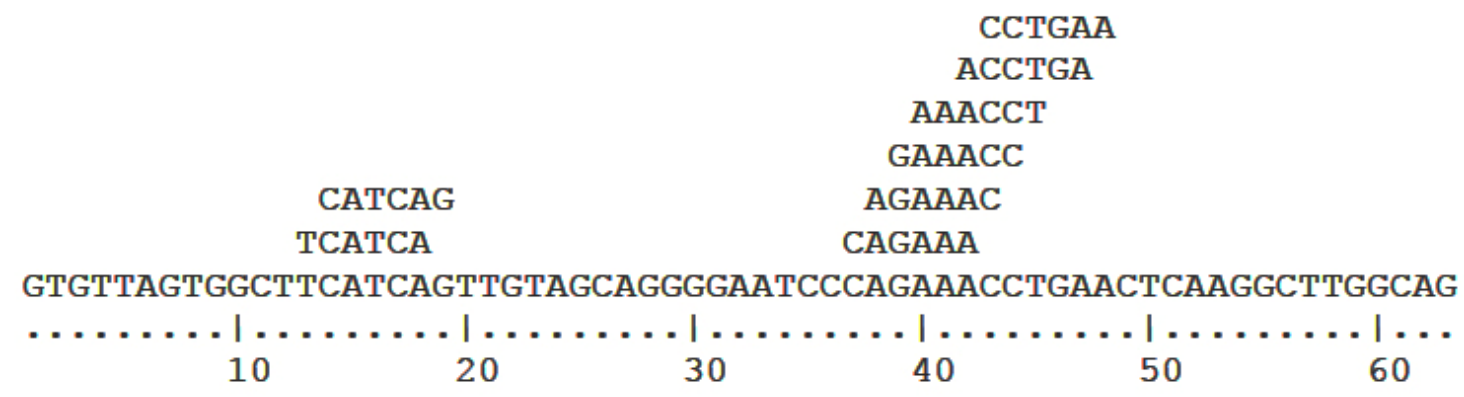

Fig. 17: Representação gráfica dos resultados das análises in silico realizadas com a ferramenta Acescan2 para o éxon 12 do FMR1 humano. (A). sequência do éxon 12 humano acima da qual estão localizados segmentos candidatos a silenciadores do splicing do éxon (B). sequência do éxon 12 humano acima da qual estão localizados segmentos candidatos a acentuadores do splicing do éxon.

\section{CAAGG}

GTGTTAGTGGCTTCATCAGTTGTAGCAGGGGAATCCCAGAAACCTGAACTCAAGGCTTGGCAG

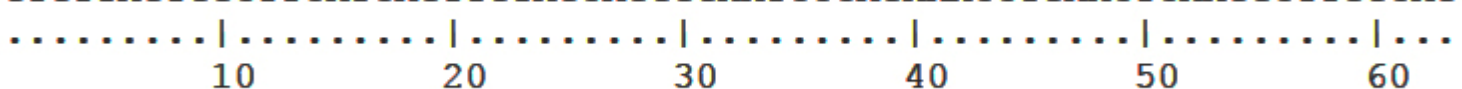

Fig. 18: Representação gráfica dos resultados das análises in silico realizadas com a ferramenta ASD - Alternative Splicing para o éxon 12 humano. Sobre sequência do éxon 12 humano está localizado o candidato a silenciador do splicing do éxon. 
A ferramenta ESE Finder, que busca especificamente acentuadores, identificou nas 63 bases do éxon 12 do Fmr1 diversas seqüências candidatas a atuarem na regulação do splicing, discriminando-as com um sistema de cores por elemento protéico em trans ligante e relacionando-as por probabilidade de ligação (Fig. 19). O fator regulador em trans denomina a seqüência em cis, que é o motivo de RNA para ligação à respectiva proteína. Embora os resultados sejam processados in silico em relação à seqüência de DNA, deve-se lembrar que a ligação in vivo e in vitro se dá entre RNA e proteína. A região com a maior densidade de candidatos identificados com probabilidades mais altas situa-se entre as bases 31 e 46 do éxon 12 e mostra potencial para interação com proteínas SF2/ASF e SC35. 


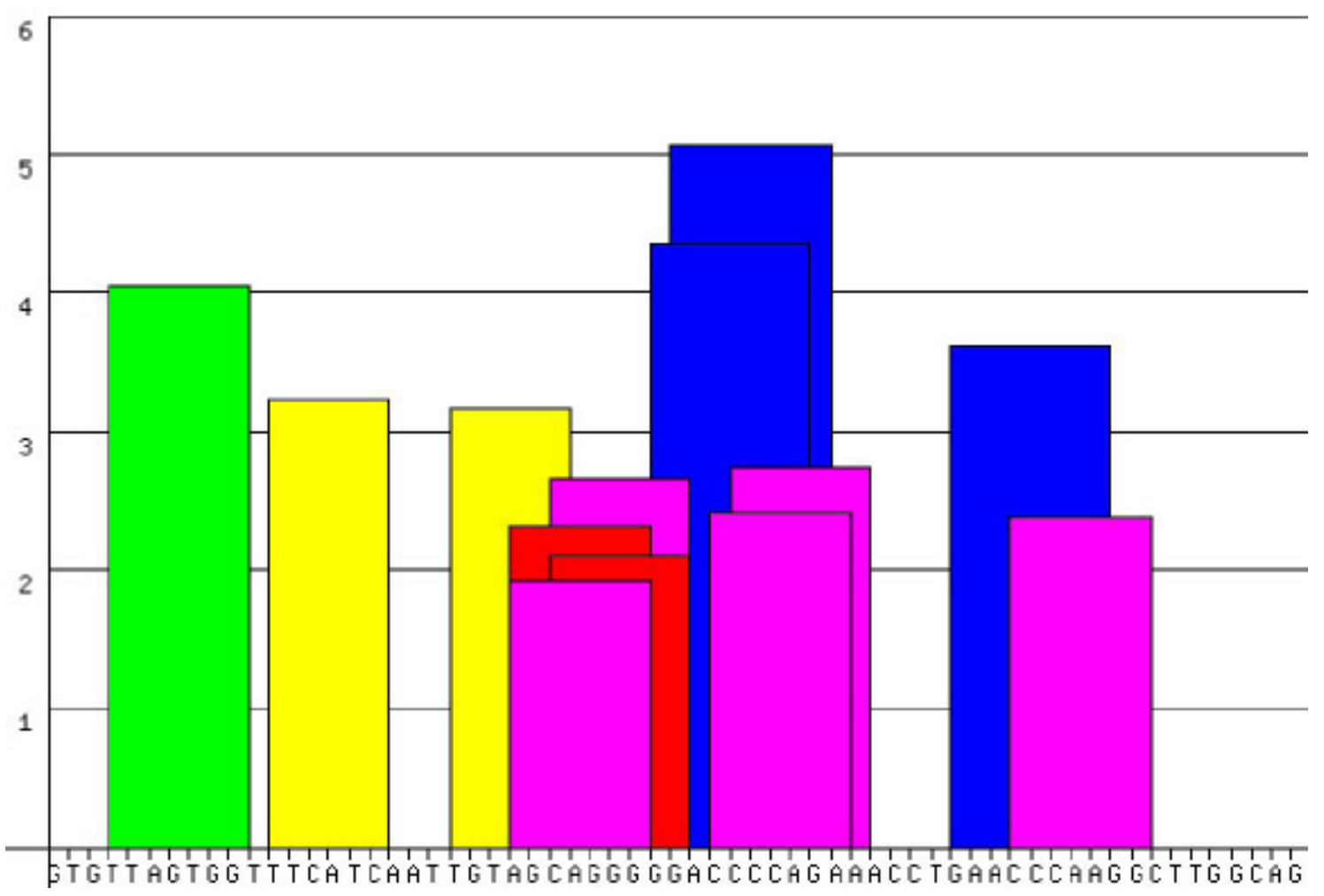

\begin{tabular}{|l|l|}
\hline SF2/ASF & \\
\hline SF2/ASF (IgM-BRCA1) & SRp40 \\
\hline SC35 & SRp55 \\
\hline
\end{tabular}

Figura 19: Representação gráfica dos resultados das análises in silico realizadas com a ferramenta ESE Finder de busca por ESEs regulatórios do splicing do éxon 12 do Fmr1 humano. No eixo horizontal está representada a seqência do éxon 12 que foi utilizada nesta busca na qual estão indicadas as posições dos nucleotídeos inicial, final, 31 e 46 . Sobre a sequência estão posicionadas colunas cujas larguras delimitam a extensão de uma sequência candidata a elemento regulatório do splicing. A cor de cada barra representa uma categoria de regulador distinta como apresentado na legenda. A altura de cada barra é determinada pelo valor no eixo vertical referente a probabilidade relativa de cada elemento identificado de participar na regulação do splicing do éxon. 
A ferramenta ESRsearch, também específica para seqüências exônicas, identificou elementos candidatos a acentuadores e silenciadores no éxon 12 do Fmr1 humano. Seqüências com função conhecida sobre o splicing foram identificadas por um sistema de cor, enquanto aquelas com função não determinada foram apenas localizadas sobre o éxon. Nesta ferramenta não é apresentado valor de probabilidade ou ligante em trans conhecido.

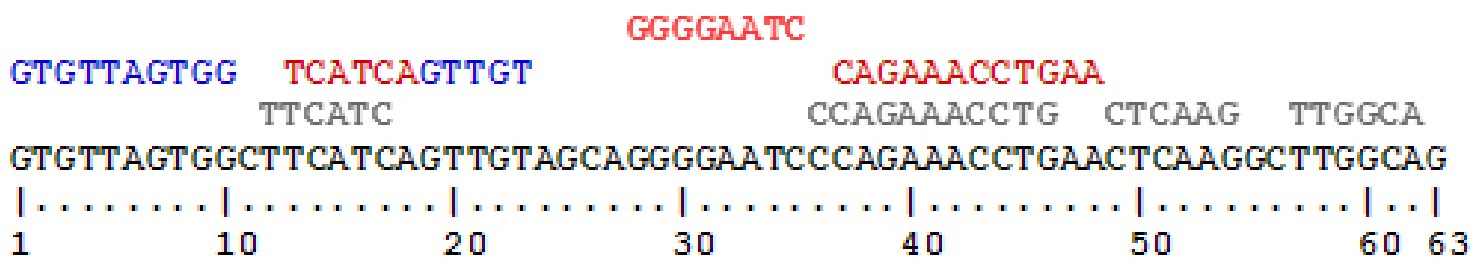

Figura 20: Representação gráfica dos resultados das análises in silico realizadas com a ferramenta ESR search de busca por elementos exônicos regulatórios do splicing do éxon 12 do Fmr1 humano. Sobre a sequência do éxon 12 estão localizados os elementos candidatos a regulação do splicing. Os elementos em azul representam silenciadores de splicing enquanto os em vermelho os acentuadores. Os elementos em cinza não possuem informações suficientes para determinar sua atuação na regulação do splicing.

As mesmas buscas realizadas a partir da seqüência humana foram realizadas na seqüência do éxon 12 do Fmr1 de camundongo, utilizando os bancos de dados específicos para a espécie. Apenas as ferramentas Acescan2 e ASD - Alternative Splicing possuem bancos de dados para esta espécie, das quais a última não retornou nenhum resultado. Na busca com Acescan2, apenas acentuadores exônicos foram identificados (Fig. 21), apresentando sobreposição quase total com os resultados no éxon 12 do FMR1 humano (Fig 17). 


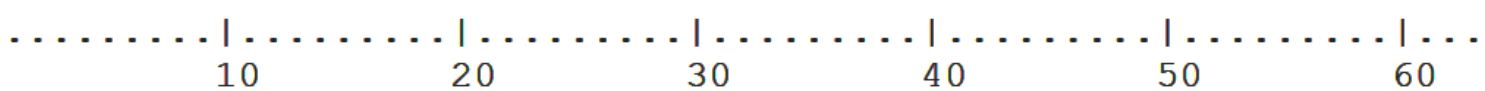

Figura 21: Representação gráfica dos resultados das análises in silico realizadas com a ferramenta Acescan2 para o éxon 12 do Fmr1 murino. Sobre a sequência do éxon estão localizados segmentos candidatos a acentuadores do splicing.

A busca utilizando a seqüência do éxon 12 do Fmr1 de rato foi realizada apenas com ASD - Alternative Splicing, a única ferramenta com banco de dados específico para esta espécie, no entanto a análise não retornou nenhum resultado.

\section{II.II Busca de ISE e ISS no íntron 11}

Análises semelhantes foram realizadas isoladamente para os íntrons que flanqueiam o éxon 12 (respectivamente, íntron 11 e íntron 12). A seqüência completa do íntron 11 do Fmr1, que possui menos de 500pb, foi submetida à análise utilizando as ferramentas que possuem bancos de dados para elementos regulatórios intrônicos, Acescan2 e ASD - Alternative Splicing, para humano, camundongo e rato.

Com a ferramenta Acescan2 foram identificados no íntron 11 do FMR1 humano apenas elementos acentuadores do splicing (Fig. 22). 


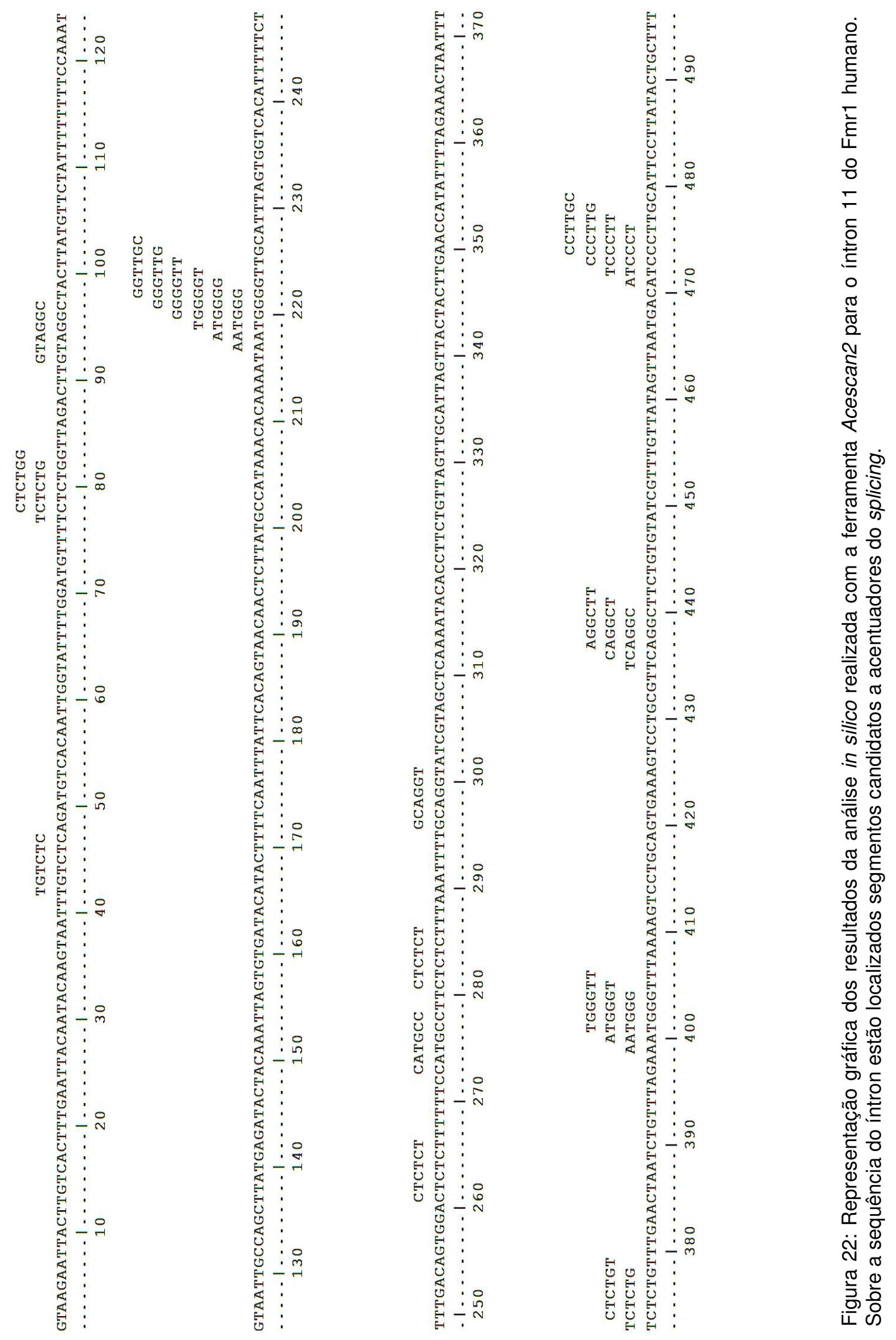


Com a ferramenta ASD - Alternative Splicing foram identificados na seqüência do íntron 11 humano apenas elementos acentuadores de splicing (Fig. 23).

\begin{tabular}{|c|c|c|}
\hline $\begin{array}{l}\text { Match at } 70 \text { nts (100 sim\%) } \\
\text { (intronic) ISE - amvloid } \\
\text { precursor protein, exon } 8\end{array}$ & $\begin{array}{l}\text { query } \\
\text { subject }\end{array}$ & $\frac{\text { ATGTTT }}{\text { ggtattttggATGTTTtctctg}}$ \\
\hline $\begin{array}{l}\text { Match at } 79 \mathrm{nts}(100 \mathrm{sim} \%) \\
\text { (intronic) ISE - } \underline{\text { dmpk .exon }} \\
\underline{16}\end{array}$ & $\begin{array}{l}\text { query } \\
\text { subject }\end{array}$ & $\begin{array}{l}\text { CTGN } \\
\text { gatgttttctCTGGttagacttgt }\end{array}$ \\
\hline $\begin{array}{l}\text { Match at } 323 \text { nts (100 sim\%) } \\
\text { (intronic) ISE - } \underline{\text { dmpk exon }} \\
\underline{16}\end{array}$ & $\begin{array}{l}\text { query } \\
\text { subject }\end{array}$ & $\begin{array}{c}\text { CTGN } \\
\text { aatacaccttCTGTtagttgcatt }\end{array}$ \\
\hline $\begin{array}{l}\text { Match at } 375 \text { nts (100 sim \%) } \\
\text { (intronic) ISE - } \underline{\text { dmpk exon }} \\
\underline{16}\end{array}$ & $\begin{array}{l}\text { query } \\
\text { subject }\end{array}$ & $\begin{array}{c}\text { CTGN } \\
\text { ctaattttctCTGTttgaactaat }\end{array}$ \\
\hline 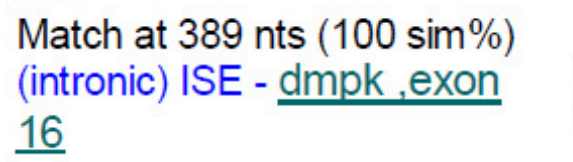 & $\begin{array}{l}\text { query } \\
\text { subject }\end{array}$ & $\begin{array}{c}\text { CTGN } \\
\text { ttgaactaatCTGTttagaaatgg }\end{array}$ \\
\hline 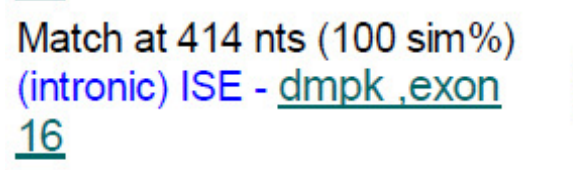 & $\begin{array}{l}\text { query } \\
\text { subject }\end{array}$ & $\begin{array}{c}\text { CTGN } \\
\text { tttaaaagtcCTGCagtgaaagtc }\end{array}$ \\
\hline 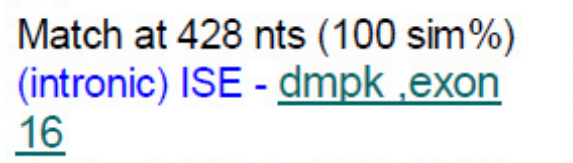 & $\begin{array}{l}\text { query } \\
\text { subject }\end{array}$ & $\begin{array}{c}\text { CTGN } \\
\text { agtgaaagtcCTGCgttcaggctt }\end{array}$ \\
\hline $\begin{array}{l}\text { Match at } 442 \text { nts (100 sim\%) } \\
\text { (intronic) ISE - dmpk .exon } 16\end{array}$ & $\begin{array}{l}\text { query } \\
\text { subject }\end{array}$ & $\begin{array}{c}\text { CTGN } \\
\text { gttcaggcttCTGTgtatcgtttg }\end{array}$ \\
\hline $\begin{array}{l}\text { Match at } 489 \text { nts (100 sim\%) } \\
\text { (intronic) ISE - dmpk exon } 16\end{array}$ & $\begin{array}{l}\text { query } \\
\text { subject }\end{array}$ & $\begin{array}{c}\text { CTGN } \\
\text { attccttataCTGCtttag }\end{array}$ \\
\hline $\begin{array}{l}\text { Match at } 218 \text { nts (100 sim\%) } \\
\text { (intronic) ISE - beta } \\
\text { tropomyosin intron } 6\end{array}$ & $\begin{array}{l}\text { query } \\
\text { subject }\end{array}$ & $\begin{array}{c}\text { WGGG } \\
\text { cacaaataaTGGGgttgcattta }\end{array}$ \\
\hline $\begin{array}{l}\text { Match at } 400 \text { nts (100 sim\%) } \\
\text { (intronic) ISE - beta } \\
\text { tropomyosin intron } 6 \\
\end{array}$ & $\begin{array}{l}\text { query } \\
\text { subject }\end{array}$ & $\begin{array}{c}\text { WGGG } \\
\text { tgtttagaaaTGGGtttaaaagtc }\end{array}$ \\
\hline
\end{tabular}

Figura 23: Representação gráfica dos resultados da análise in silico realizada com a ferramenta ASD - Alternative Splicing para o íntron 11 do FMR1 humano. Sobre a sequência do íntron estão localizados segmentos candidatos a acentuadores do splicing. 
Para a seqüência do íntron 11 do Fmr1 murino foram utilizadas as ferramentas que possuem bancos de dados para esta espécie, Acescan2 e ASD - Alternative Splicing, das quais a última não retornou resultados. Na busca com Acescan2 foram identificados apenas acentuadores intrônicos (Fig. 24)

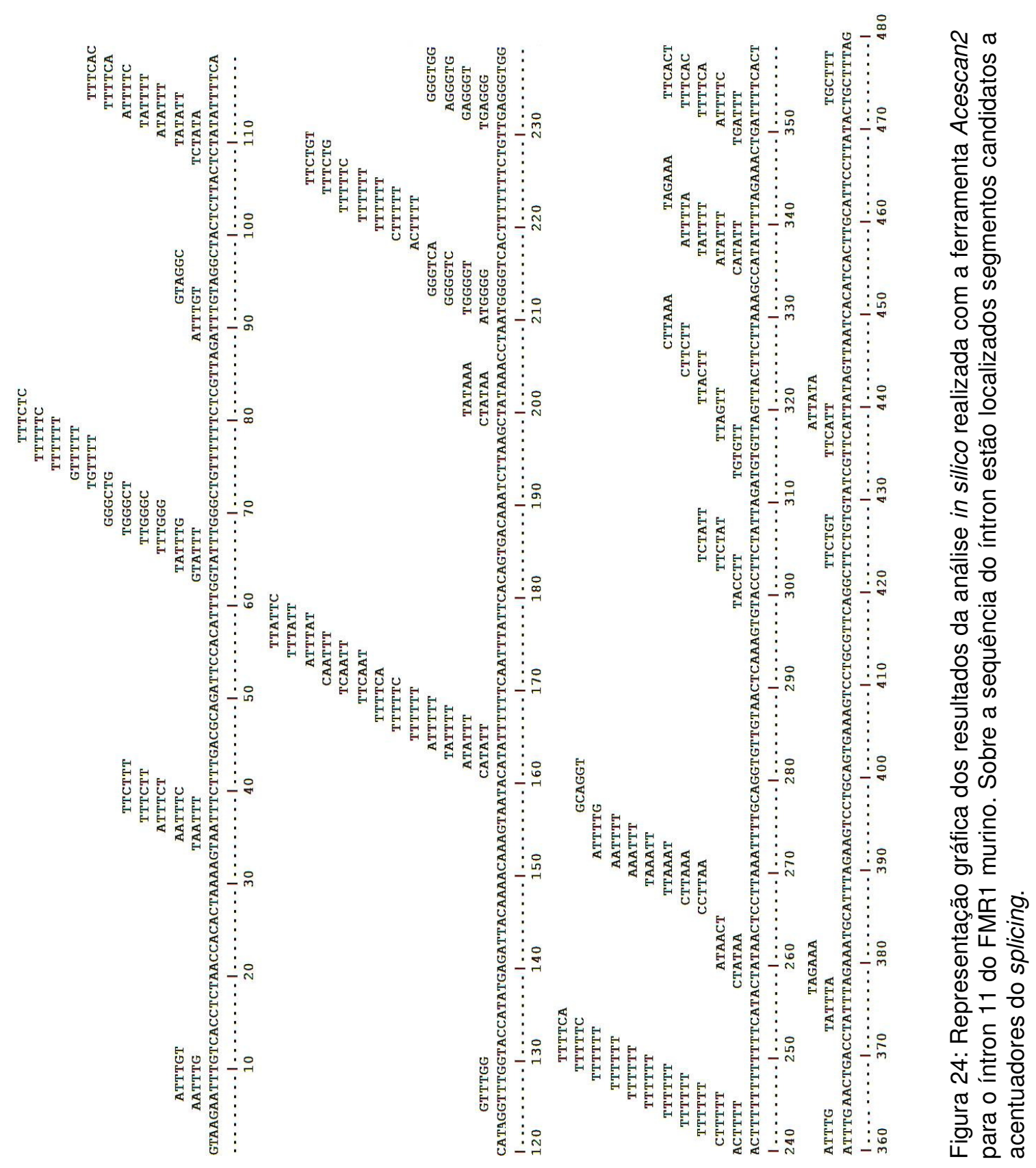


A mesma análise in silico foi realizada para o íntron 11 do Fmr1 de rato com a única ferramenta que dispõe de banco de dado para esta espécie, ASD - Alternative Splicing. Esta busca identificou apenas um elemento regulatório intrônico acentuador de splicing (Fig. 25), que tem como ligantes em trans reconhecidos as proteínas SF2/ASF e hnRNP H.

Match at $229 \mathrm{nts}$

(100 $\operatorname{sim} \%)$

(intronic) ISE -

thyroid hormone

receptor, exon 9

Figura 25: Representação gráfica dos resultados da análise in silico realizada com a ferramenta ASD - Alternative Splicing para o íntron 11 do Fmr1 de rato. Sobre a sequência do íntron está localizado o segmento candidato a acentuador do splicing.

\section{II.III Busca por ISE e ISS no íntron 12}

Para as buscas de elementos regulatórios de splicing no íntron 12 de Fmr1 foram utilizados os 500pb a 5' deste íntron, região mais provável para a presença de elementos que influenciam a inclusão éxon 12. Foram utilizadas nesta análise as duas ferramentas que possuem bancos de dados para busca de seqüências intrônicas, Acescan2 e ASD - Alternative Splicing, para as seqüências de humano, camundongo e rato.

Na busca com Acescan2 foram identificados apenas elementos acentuadores de splicing (Fig. 26). 


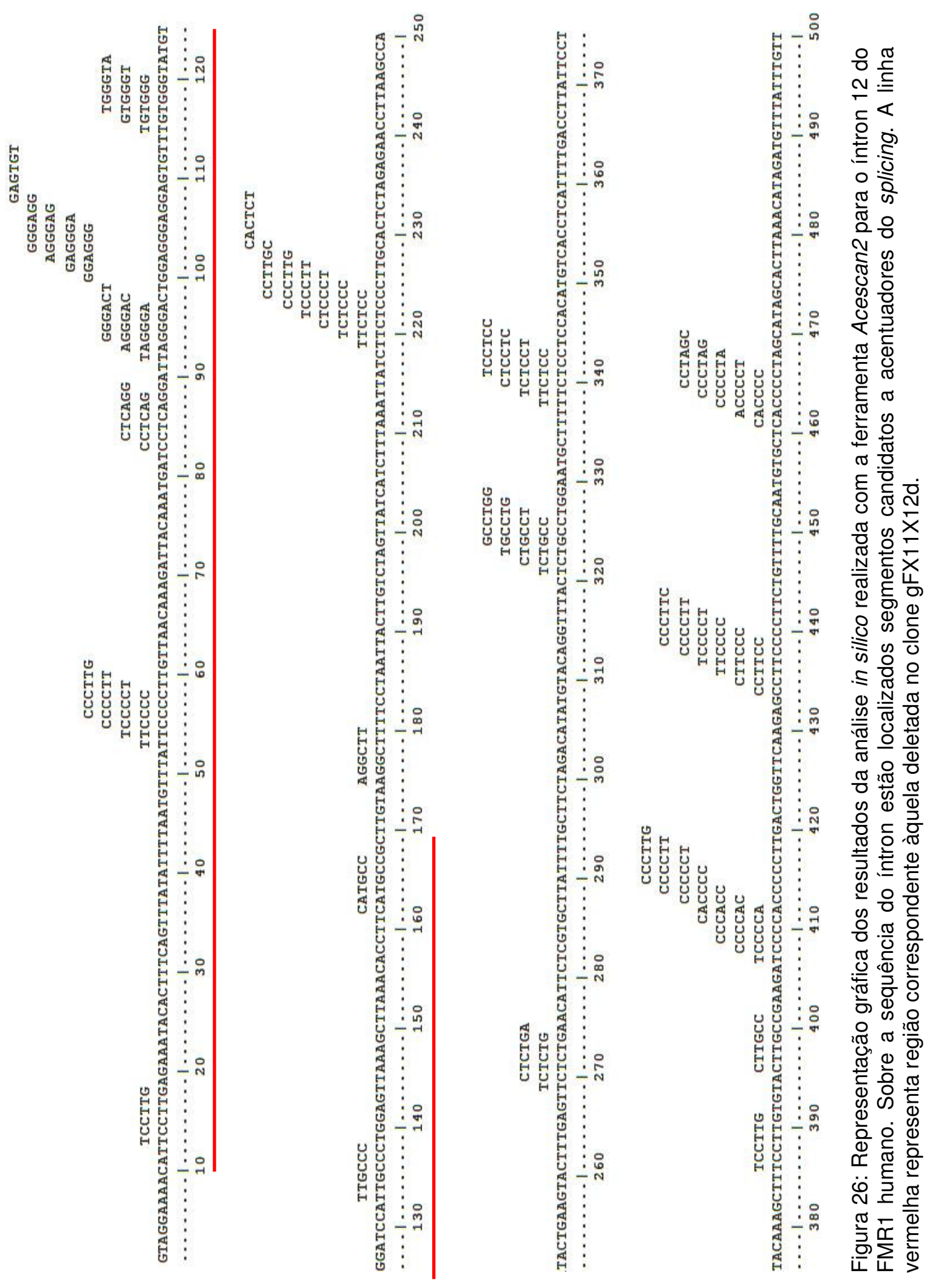


A ferramenta ASD - Alternative Splicing identificou no íntron 12 do FMR1 humano diversas seqüências candidatas a elementos acentuadores de splicing e apenas uma com potencial para atuar como silenciador intrônico, nenhuma delas com ligantes em trans conhecidos (Fig. 27).

\begin{tabular}{|c|c|c|}
\hline $\begin{array}{l}\text { Match at } 45 \mathrm{nts}(100 \mathrm{sim} \%) \\
\text { (intronic) ISE - amyloid } \\
\text { precursor protein, exon } 8 \\
\end{array}$ & $\begin{array}{l}\text { query } \\
\text { subject }\end{array}$ & $\begin{array}{c}\text { ATGTTT } \\
\text { ttatattttaATGTTTattcccettg }\end{array}$ \\
\hline $\begin{array}{l}\text { Match at } 487 \text { nts ( } 100 \operatorname{sim} \%) \\
\text { (intronic) ISE - amyloid } \\
\text { precursor protein, exon } 8\end{array}$ & $\begin{array}{l}\text { query } \\
\text { subject }\end{array}$ & $\begin{array}{c}\text { ATGTTT } \\
\text { ttaaacatagATGTTTatttgtt }\end{array}$ \\
\hline $\begin{array}{l}\text { Match at } 97 \mathrm{nts}(100 \mathrm{sim} \%) \\
\text { (intronic) ISE - } \underline{\mathrm{dmpk}, \text { exon }} \\
\underline{16}\end{array}$ & $\begin{array}{l}\text { query } \\
\text { subject }\end{array}$ & $\begin{array}{c}\text { CTGN } \\
\text { ggattagggaCTGGagggaggagt }\end{array}$ \\
\hline $\begin{array}{l}\text { Match at } 137 \mathrm{nts}(100 \operatorname{sim} \%) \\
\text { (intronic) ISE - dmpk, exon } 16\end{array}$ & $\begin{array}{l}\text { query } \\
\text { subject }\end{array}$ & $\begin{array}{c}\text { CTGN } \\
\text { atccattgCCCTGGagttaaagct }\end{array}$ \\
\hline $\begin{array}{l}\text { Match at } 252 \text { nts (100 sim \%) } \\
\text { (intronic) ISE - dmpk, exon } 16\end{array}$ & $\begin{array}{l}\text { query } \\
\text { subject }\end{array}$ & $\begin{array}{c}\text { CTGN } \\
\text { ttaagccataCTGAagtactttga }\end{array}$ \\
\hline $\begin{array}{l}\text { Match at } 271 \text { nts (100 sim \%) } \\
\text { (intronic) ISE - dmpk, exon } 16\end{array}$ & $\begin{array}{l}\text { query } \\
\text { subject }\end{array}$ & $\begin{array}{c}\text { CTGN } \\
\text { tttgagttctCTGAacattctcgt }\end{array}$ \\
\hline $\begin{array}{l}\text { Match at } 321 \text { nts }(100 \operatorname{sim} \%) \\
\text { (intronic) ISE - } \underline{\text { dmpk ,exon } 16}\end{array}$ & $\begin{array}{l}\text { query } \\
\text { subject }\end{array}$ & $\begin{array}{c}\text { CTGN } \\
\text { caggtttactCTGCCtggaatgct }\end{array}$ \\
\hline $\begin{array}{l}\text { Match at } 325 \text { nts (100 sim \%) } \\
\text { (intronic) ISE - dmpk, exon } 16\end{array}$ & $\begin{array}{l}\text { query } \\
\text { subject }\end{array}$ & $\begin{array}{c}\text { CTGN } \\
\text { tttactctgcCTGGaatgctttt }\end{array}$ \\
\hline $\begin{array}{l}\text { Match at } 421 \text { nts (100 sim } \%) \\
\text { (intronic) ISE - dmpk ,exon } 16 \\
\end{array}$ & $\begin{array}{l}\text { query } \\
\text { subject }\end{array}$ & $\begin{array}{c}\text { CTGN } \\
\text { acccccttgaCTGGttcaagagcC }\end{array}$ \\
\hline $\begin{array}{l}\text { Match at } 443 \text { nts (100 sim \%) } \\
\text { (intronic) ISE - dmpk ,exon } 16\end{array}$ & $\begin{array}{l}\text { query } \\
\text { subject }\end{array}$ & $\begin{array}{c}\text { CTGN } \\
\text { ccttccccttCTGTttgcaatgt }\end{array}$ \\
\hline $\begin{array}{l}\text { Match at } 92 \text { nts (100 sim\%) } \\
\text { (intronic) ISE - beta } \\
\text { tropomyosin intron } 6 \\
\end{array}$ & $\begin{array}{l}\text { query } \\
\text { subject }\end{array}$ & $\begin{array}{c}\text { WGGG } \\
\text { cctcaggattAGGGactggaggga }\end{array}$ \\
\hline $\begin{array}{l}\text { Match at } 101 \mathrm{nts}(100 \mathrm{sim} \%) \\
\text { (intronic) ISE - beta } \\
\text { tropomyosin intron } 6 \\
\end{array}$ & $\begin{array}{l}\text { query } \\
\text { subject }\end{array}$ & $\begin{array}{c}\text { WGGG } \\
\text { tagggactggAGGGaggagtgttt }\end{array}$ \\
\hline $\begin{array}{l}\text { Match at } 116 \text { nts ( } 100 \mathrm{sim} \%) \\
\text { (intronic) ISE - beta } \\
\text { tropomyosin intron } 6 \\
\end{array}$ & $\begin{array}{l}\text { query } \\
\text { subject }\end{array}$ & $\begin{array}{c}\text { WGGG } \\
\text { ggagtgtttgTGGGtatgtggatc }\end{array}$ \\
\hline $\begin{array}{l}\text { Match at } 87 \mathrm{nts}(100 \mathrm{sim} \%) \\
\text { (intronic) ISE - gh-1 intron } 3 \\
\end{array}$ & $\begin{array}{l}\text { query } \\
\text { subject }\end{array}$ & $\begin{array}{c}\text { GGNNNNGGG } \\
\text { atgatcctcaGGATTAGGGactggaggga }\end{array}$ \\
\hline $\begin{array}{l}\text { Match at } 452 \text { nts (100 sim\%) } \\
\text { (intronic) ESS - pcca: } \\
\text { propionyl coenzyme a } \\
\text { carboxylase, alpha } \\
\text { polypeptide(intron2) }\end{array}$ & $\begin{array}{l}\text { query } \\
\text { subject }\end{array}$ & $\begin{array}{c}\text { AATGTG } \\
\text { tctgttttgcAATGTGctcaccccta }\end{array}$ \\
\hline
\end{tabular}

Figura 27: Representação gráfica dos resultados da análise in silico realizada com a ferramenta ASD - Alternative Splicing para o íntron 12 do FMR1 humano. Sobre a sequência do íntron estão localizados segmentos candidatos a reguladores do splicing. Está indicado com um retângulo o único elemento identificado candidaato a silenciador de splicing. 
As buscas no íntron 12 foram realizadas para a seqüência de camundongo com as mesmas ferramentas que possuem bancos de dados de elementos intrônicos. $\mathrm{Na}$ análise com Acescan2 foram identificadas apenas elementos candidatos a acentuadores de splicing (Fig. 28).

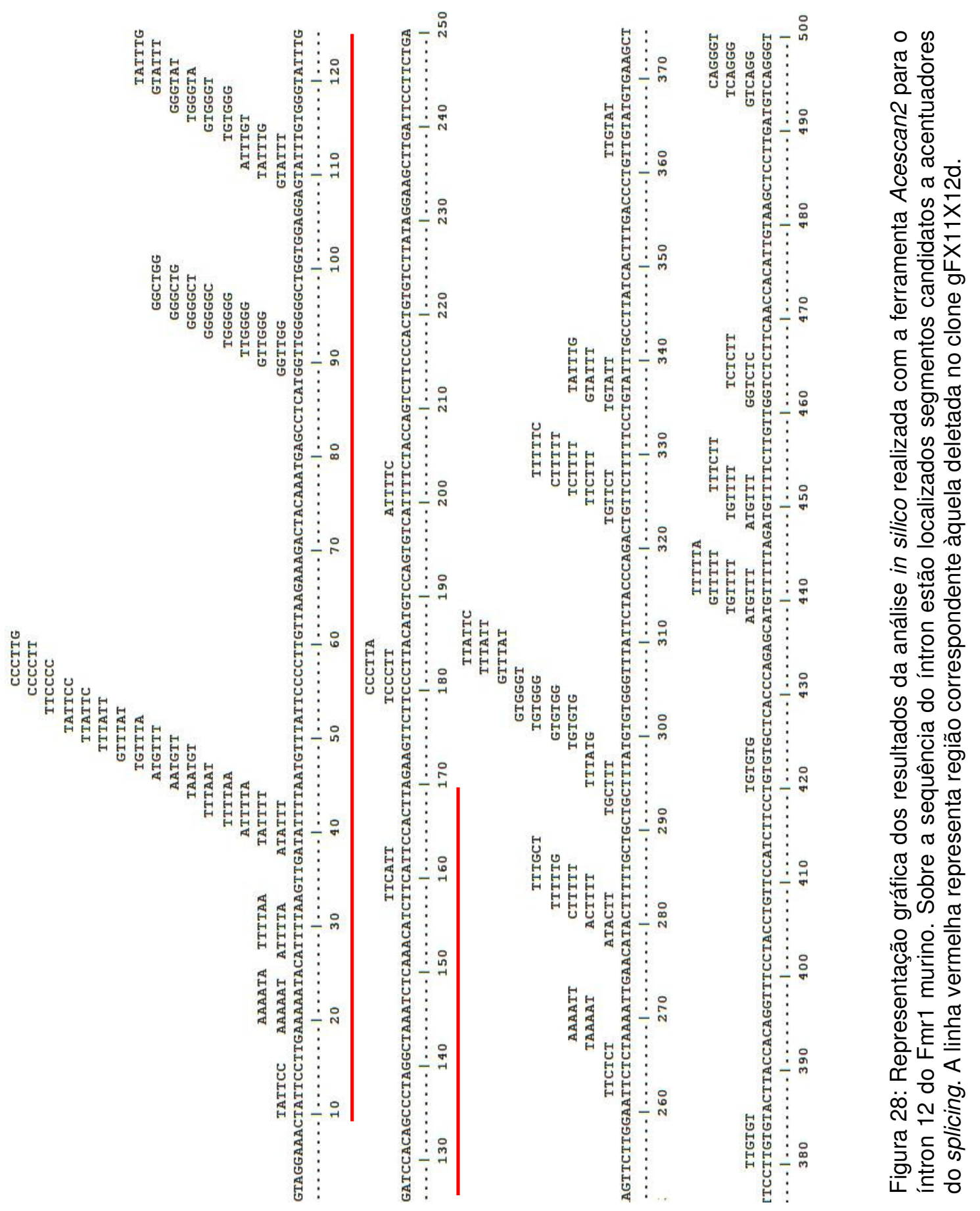


Para o íntron 12 murino foi também identificada apenas uma seqüência candidata a elemento silenciador de splicing com a ferramenta ASD - Alternative Splicing (Fig. 29). Este elemento tem diversos ligantes em trans já identificados, PTB/nPTB, KSRP, FBP, hnRNP H e hnRNP F.

Match at 92 nts

$(100 \operatorname{sim} \%) \quad$ query

GGGGGCTG

(intronic) ISS - subject

cctcatggttGGGGGCTGgtggaggagt

c-src. exon n1

Figura 29: Representação gráfica do resultado da análise in silico realizada com a ferramenta ASD - Alternative Splicing para o íntron 12 do Fmr1 de camundongo. Sobre a sequência do íntron está localizado o segmento candidato a silenciador do splicing.

A busca por elementos na seqüência do íntron 12 do Fmr1 de rato foi realizada com

a única ferramenta que possui banco de dados para elementos intrônicos desta espécie, no entanto a análise não retornou nenhum resultado.

\section{Estudo da expressão do mini-gene do éxon 12 do Fmr1:}

\section{III.I Obtenção do clone de Fmr1 tipo selvagem}

Para estudar a regulação do splicing do éxon 12 do Fmr1 foi criado um mini-gene, que consiste em um segmento genômico do Fmr1 contendo o éxon de interesse e os dois éxons adjacentes (Fig. 30). Este segmento, amplificado por PCR, foi ligado direcionalmente em um vetor de expressão clonado em bactéria e posteriormente transfectado em célula animal. A expressão deste vetor gera um RNA contendo o segmento de Fmr1 clonado flanqueado por uma região 3' não traduzida e uma 
sequência ( $F L A G)$ a 5' contida no vetor. A maquinaria de splicing da célula pode gerar possivelmente dois transcritos maduros, que diferem pela inclusão do éxon 12 . 0 estudo do RNAm da célula permite averiguar o padrão de expressão deste mini-gene (Fig. 30).

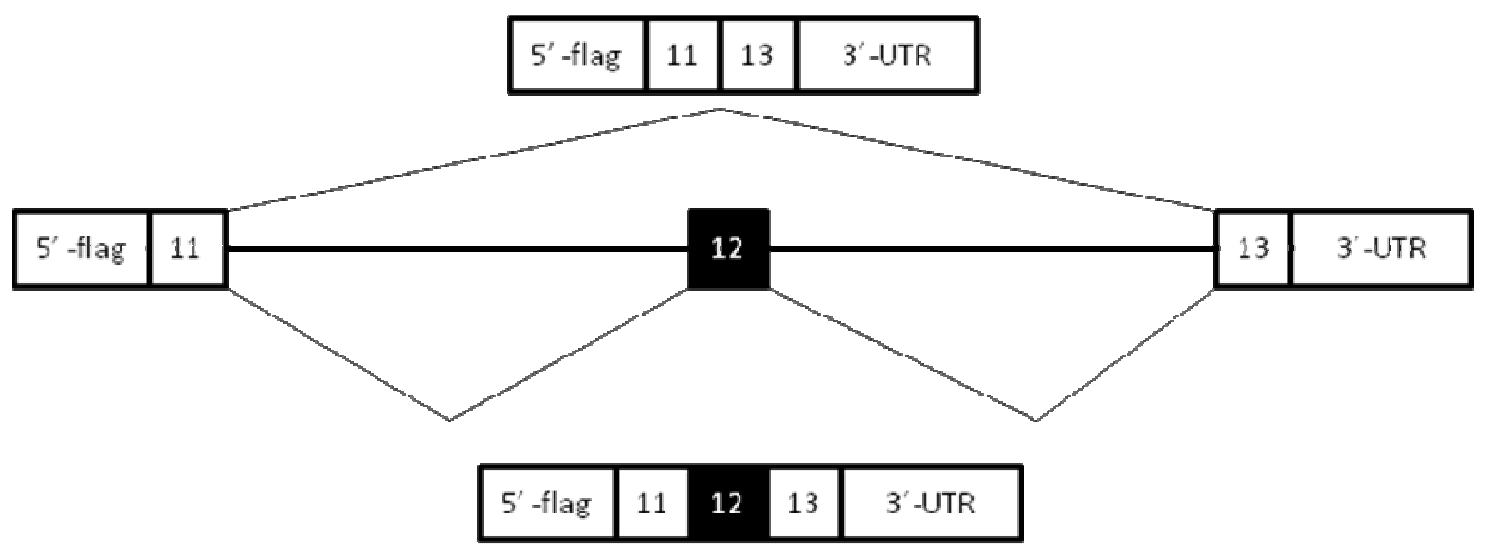

Fig. 30: Representação esquemática do inserto do vetor PCDNA3 que consistirá o mini-gene gerado com o segmento do Fmr1 que inclui da primeira base do éxon 11 a última do éxon 13. O RNA produzido a partir deste mini-gene inclui o segmento clonado flanqueado por uma sequência não traduzida a 3' e uma sequência sinal (FLAG) a 5' originados do vetor utilizado. $\mathrm{O}$ splicing deste RNA pode gerar transcritos maduros que incluem ou excluem o éxon 12. Os números nas caixas indicam os segmentos expressos.

Para a construção do mini-gene contendo parte da seqüência genômica do Fmr1 que abrange do éxon 11 ao éxon 13, DNA genômico de fêmeas de Rattus Norvegicus foi utilizado em reações de amplificação por PCR. Nesta reação, com iniciadores específicos que flanqueiam a região clonada e polimerase de alta fidelidade para evitar a introdução in vitro de erros de seqüência, obtivemos produto de tamanho esperado (2849pb), como observado em eletroforese em gel de agarose (Fig 31). 


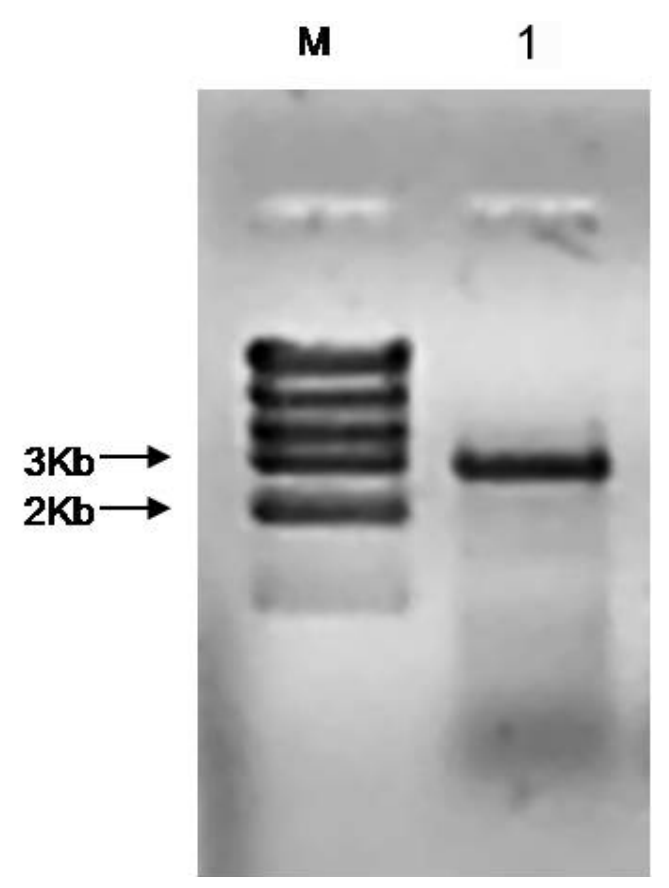

Figura 31: Gel de agarose a 0,8\% em que foram submetidos a eletroforese $10 \mu \mathrm{L}$ de produto de PCR da amplificação do segmento genômico utilizado na construção do clone. (1) Segmento genômico que compreende os éxons 11 ao 13 do Fmr1 com tamanho esperado de 2849pb. Padrão de tamanho e peso molecular High Mass DNA Ladder, cujas bandas de $3 \mathrm{~Kb}$ e $2 \mathrm{~Kb}$ estão indicadas (M). Após eletroforese o gel foi corado com brometo de etídio e observado à luz ultravioleta.

O DNA amplificado foi clonado no vetor TOPO PCR 2.1 em Escherichia coli DH5a e o DNA plasmidial dos clones foi submetido à PCR para identificar aquelas recombinantes (Fig. 32). 20 colônias foram analisadas pela PCR com iniciadores que hibridavam no inserto. Destas, 14 apresentaram produto de PCR do tamanho esperado. DNA plasmidial foi purificado e submetido à digestão dupla com as enzimas EcoRV e Notl, cujos sítios de restrição haviam sido inseridos na seqüência dos iniciadores usados na amplificação do DNA genômico do Fmr1. 
A

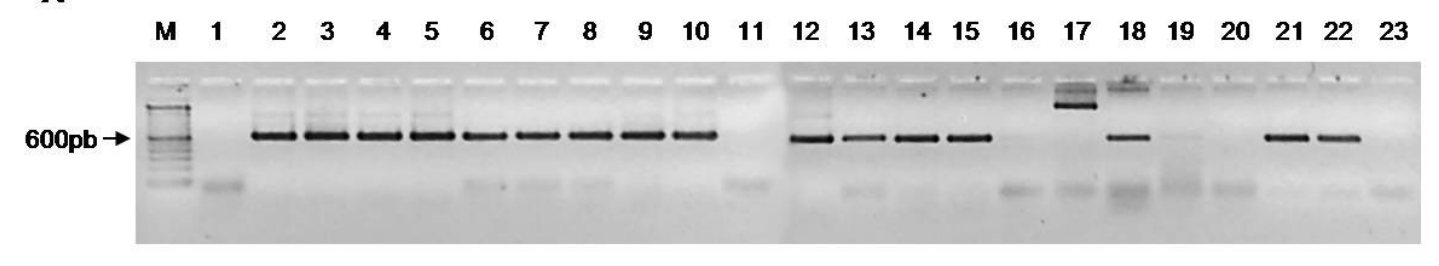

в

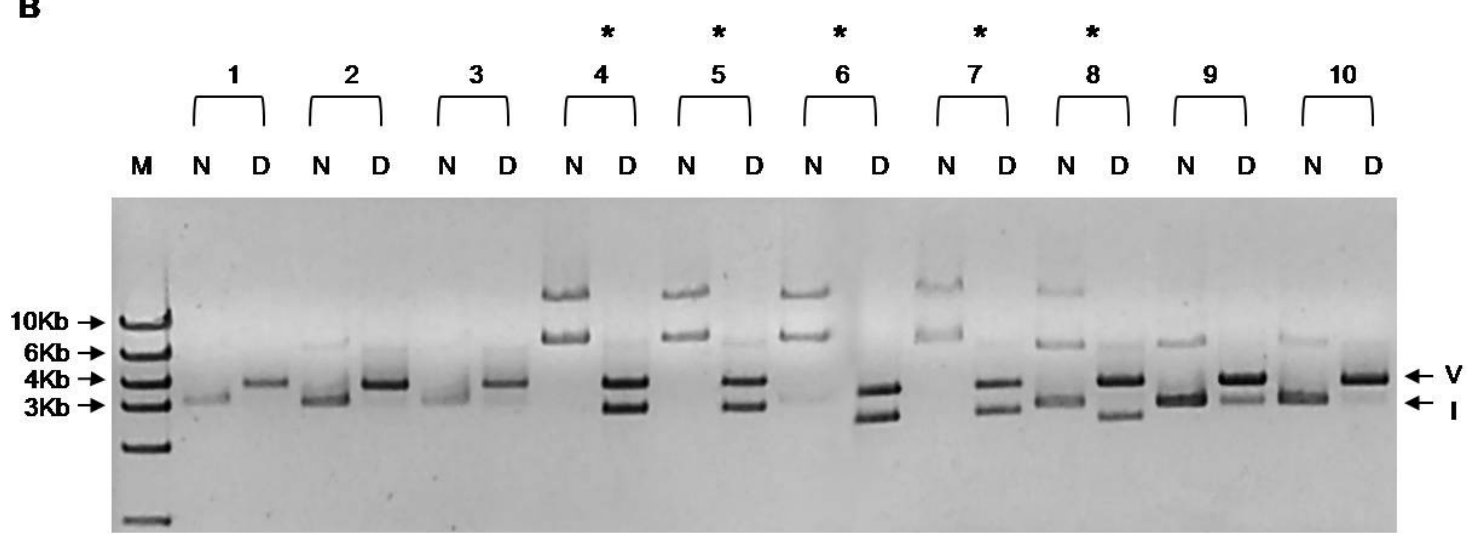

Figura 32: (A). Gel de agarose a $2 \%$ em que foram submetidos à eletroforese $10 \mu \mathrm{L}$ de produtos de PCR das reações para triagem das colônias de bactéria transformadas com produtos da ligação do vetor TOPO e produto de PCR (Fmr1 X11 a X13) (1 a 20). Os iniciadores eram internos ao inserto e definiam um produto de $631 \mathrm{pb}$. Amostras de DNA genômico de ratas adultas na reação de PCR como controle positivo (21 e 22). Uma reação de PCR no qual não foi aplicado amostra de DNA ou bactéria foi utilizada como controle negativo (23). (M) Padrão de tamanho e peso molecular 100bp DNA Ladder, cuja banda de tamanho 600pb esta indicada, região em que se observa também o produto de PCR $(631 \mathrm{pb})$ de colônias positivas. Após eletroforese o gel foi corado com brometo de etídio e observado à luz ultravioleta.

(B). Gel de agarose a $0,8 \%$ em que foram submetidos a eletroforese $10 \mu \mathrm{L}$ de amostras de plasmídios extraídas de dez colônias positivas pela triagem por PCR. Amostras não digeridas (N) apresentam bandas com migração mais rápida no gel de agarose $(1,2,3,9$ e 10) ou lenta $(4,5$, 6,7 e 8). Amostras digeridas com EcoRV e Notl (D) mostraram a banda do vetor linearizado $(\sim 5 \mathrm{~Kb})$ indicada como " $\mathrm{V}$ ". a ausência de outra banda para amostras digeridas (1, 2, 3 e 10) indicam que estes clones não são recombinantes. Amostras 4 a 8 são de clones recombinantes como indicado pela presença de banda de cerca de $3 \mathrm{~Kb}$ (I) do tamanho esperado do produto de PCR do Fmr1 (X11 a X13). A amostra 9 é provavelmente recombinante que sofreu contaminação. (M) Padrão de tamanho e peso molecular High Mass DNA Ladder, cujas bandas de tamanhos $3 \mathrm{~Kb}, 4 \mathrm{~Kb}, 6 \mathrm{~Kb}$ e $10 \mathrm{~Kb}$ estão indicadas. Após eletroforese o gel foi corado com brometo de etídio e observado à luz ultravioleta. 
Uma das colônias transformantes (Fig 32, clone 4) foi selecionada para subclonagem em vetor pcDNA3 com as enzimas EcoRV e Notl. O vetor d pcDNA3.1 é um vetor de expressão em células de mamíferos, cuja transcrição a 5' do sítios de clonagem múltipla é dirigida pelo promotor do citomegalovirus (CMV). O vetor contém um códon de iniciação de tradução seguido da região codificadora para o marcador FLAG, o sítio de clonagem múltipla, códons de parada de tradução em várias molduras de leitura sítios de poliadenilação. A escolha da clonagem seqüencial, inicialmente no vetor TOPO PCR 2.1 e posteriormente ao vetor pcDNA3.1, deve-se à maior eficiência de clonagem no primeiro vetor.

As colônias de bactéria, geradas a partir da transformação de bactérias Escherichia coli DH5a competentes com produtos de ligação do vetor pcDNA3.1 e inserto purificado da digestão do clone TOPO recombinante, foram triadas em reações de PCR utilizando iniciadores específicos para o segmento clonado, identificando cerca de $80 \%$ pela amplificação de um produto de $631 \mathrm{pb}$ (Fig. 33). DNA plasmidial foi purificado de cinco colônias selecionadas a partir da triagem por PCR. 
A

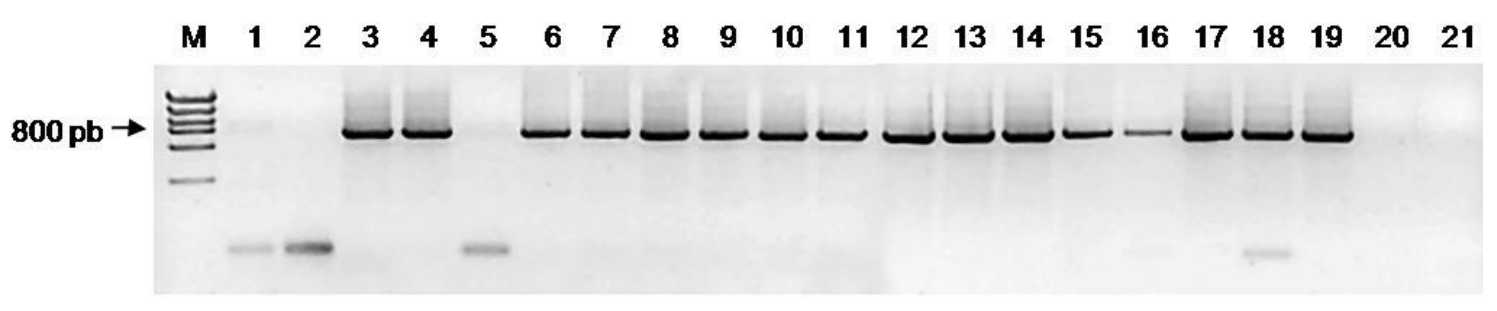

B

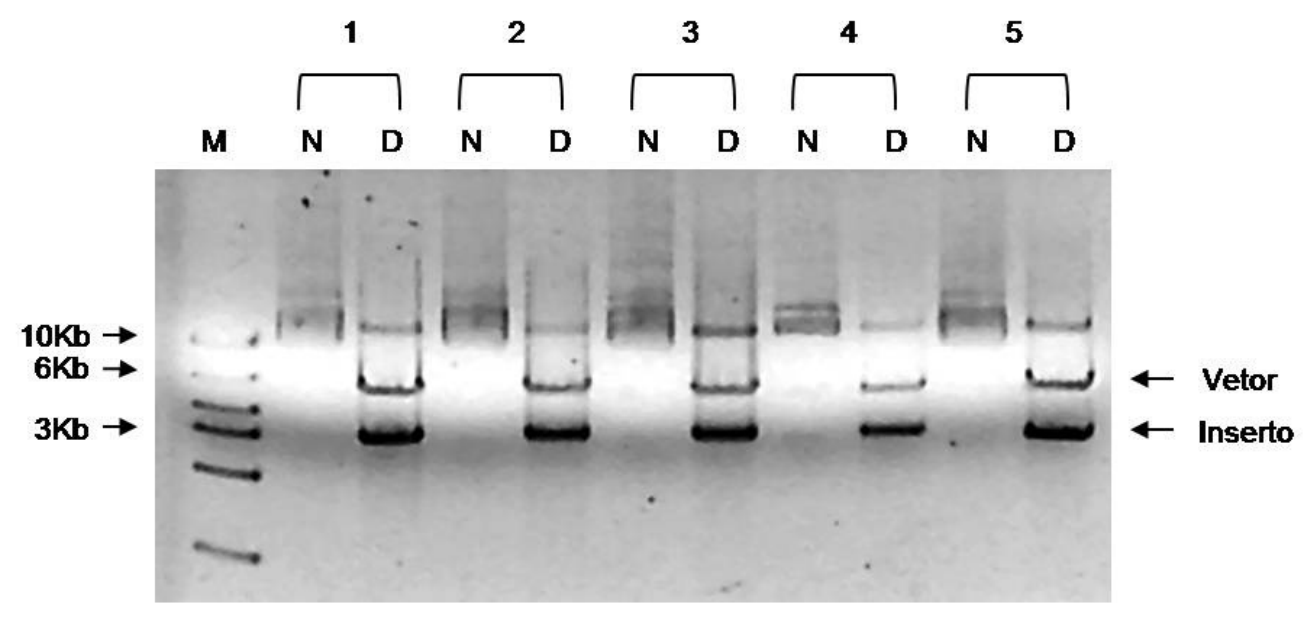

Figura 33: (A). Gel de agarose a $2 \%$ em que foram submetidos a eletroforese $10 \mu \mathrm{L}$ de produtos de PCR das reações para triagem de 20 colônias de bactéria transformadas com produtos de ligaçãodo vetor pcDNA3.1 e fragmento do Fmr1 (1 a 20). O tamanho esperado para estas bandas é $631 \mathrm{pb}$. Uma reação de PCR no qual não foi aplicado DNA foi utilizada como controle negativo (21). (M) Padrão de tamanho e peso molecular Low Mass DNA Ladder, cuja banda de tamanho 800pb esta indicada. Após eletroforese o gel foi corado com brometo de etídio e observado à luz ultravioleta. Os resultados indicam quize colônias recombinantes.

(B). Gel de agarose a $0,8 \%$ em que foram submetidos a eletroforese $10 \mu \mathrm{L}$ de amostras de plasmídios extraídas de bactérias. Amostras não digeridas $(\mathrm{N})$ mostraram o mesmo padrão de migração em gel de agarose. As amostras digeridas com EcoRV e Notl (D) mostraram bandas com tamanhos esperados referentes ao vetor de clonagem pcDNA3.1 ( 5,5Kb) e segmento genômico ( 3Kb) (indicados na figura). (M) Padrão de tamanho e peso molecular High Mass DNA Ladder, cujas bandas de tamanhos $3 \mathrm{~Kb}, 6 \mathrm{~Kb}$ e $10 \mathrm{~Kb}$ estão indicadas. Após eletroforese o gel foi corado com brometo de etídio e observado à luz ultravioleta. 
O segmento do inserto, no clone recombinante, foi inteiramente seqüenciado, bem como sua junção com o vetor pcDNA3.1, sem apresentar qualquer variação em relação à seqüência do Genbank (№ de acesso: NC_005120; Fig. 34).

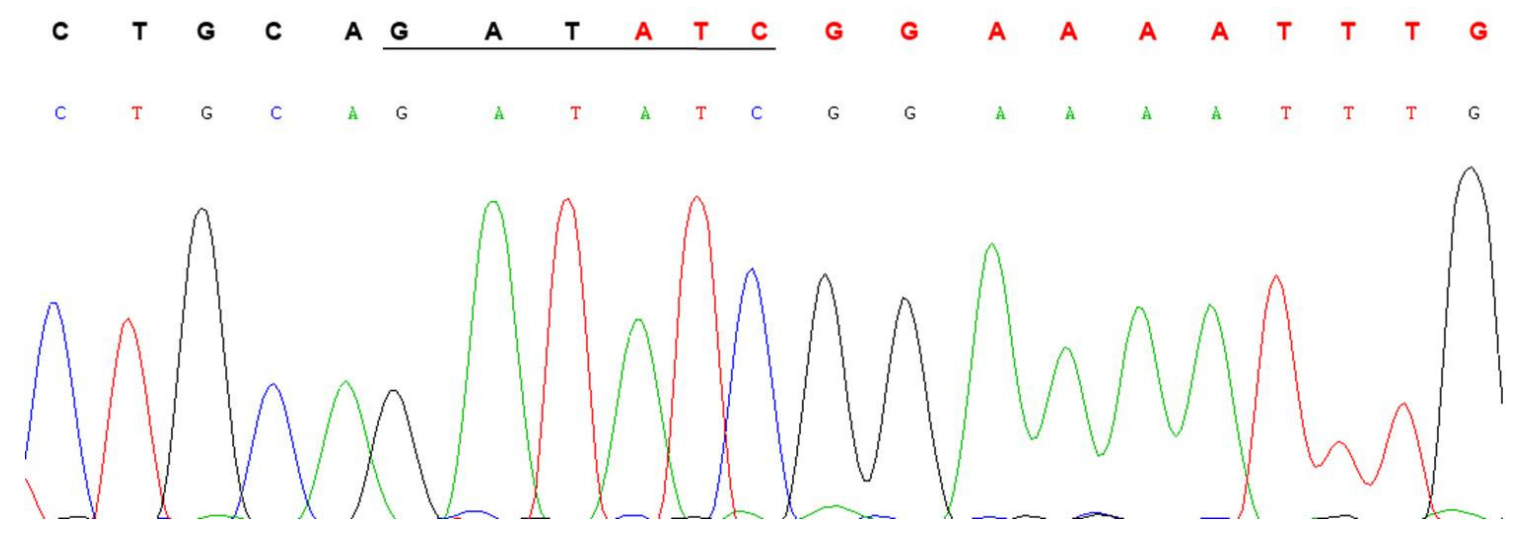

Figura 34: Exemplo de seqüenciamento parcial da sequência do clone contendo o segmento genômico de Fmr1 ligado ao vetor pcDNA3.1. O eletroferograma mostra perfil de bandas a partir so sequenciamento realizado com iniciador específico para o vetor. A sequência na linha superior é a de referência (para o vetor, em preto, e para o inserto em vermelho). O sítio de restrição para EcoRV encontra-se sublinhado.

\section{III.II Expressão do clone gFX11X13 em células C6: Análise dos produtos de} splicing

O clone gFX11X13 foi usado para transfectar células imortalizadas de glioma de rato, C6, que foram escolhidas por ser da mesma espécie do gene em estudo. Após 24 horas a expressão heteróloga foi avaliada por RT-PCR. As transfecções foram realizadas em triplicatas e com controles negativos (pcDNA3.1 não recombinante). 0 transcrito total produzido pelo clone deveria conter uma região 5' UTR, região 
codificadora do FLAG, éxons 11, 12 e 13 do Fmr1 e 3' UTR. O teste dos transcritos por RT-PCR tinha um iniciador específico à seqüência do vetor (FLAG) e outro à seqüência clonada (éxon 13 do Fmr1). Este par de iniciadores distingue a amplificação do RNAm superexpresso, não reconhecendo o a expressão do Fmr1 endógeno. O amplicom para transcritos com o éxon 12 definiu um segmento de $323 \mathrm{pb}$, enquanto os produtos de RT-PCR a partir de transcritos sem o éxon 12 têm um tamanho esperado de 260pb. O uso de antibióticos e soro, a incubação por 12 ou 48 horas e o dobro da quantidade de plasmídio não alteraram os resultados (dados não mostrados). Uma terceira banda de tamanho ligeiramente maior que a banda equivalente à inclusão do éxon 12 foi observada (Fig. 35 B). 

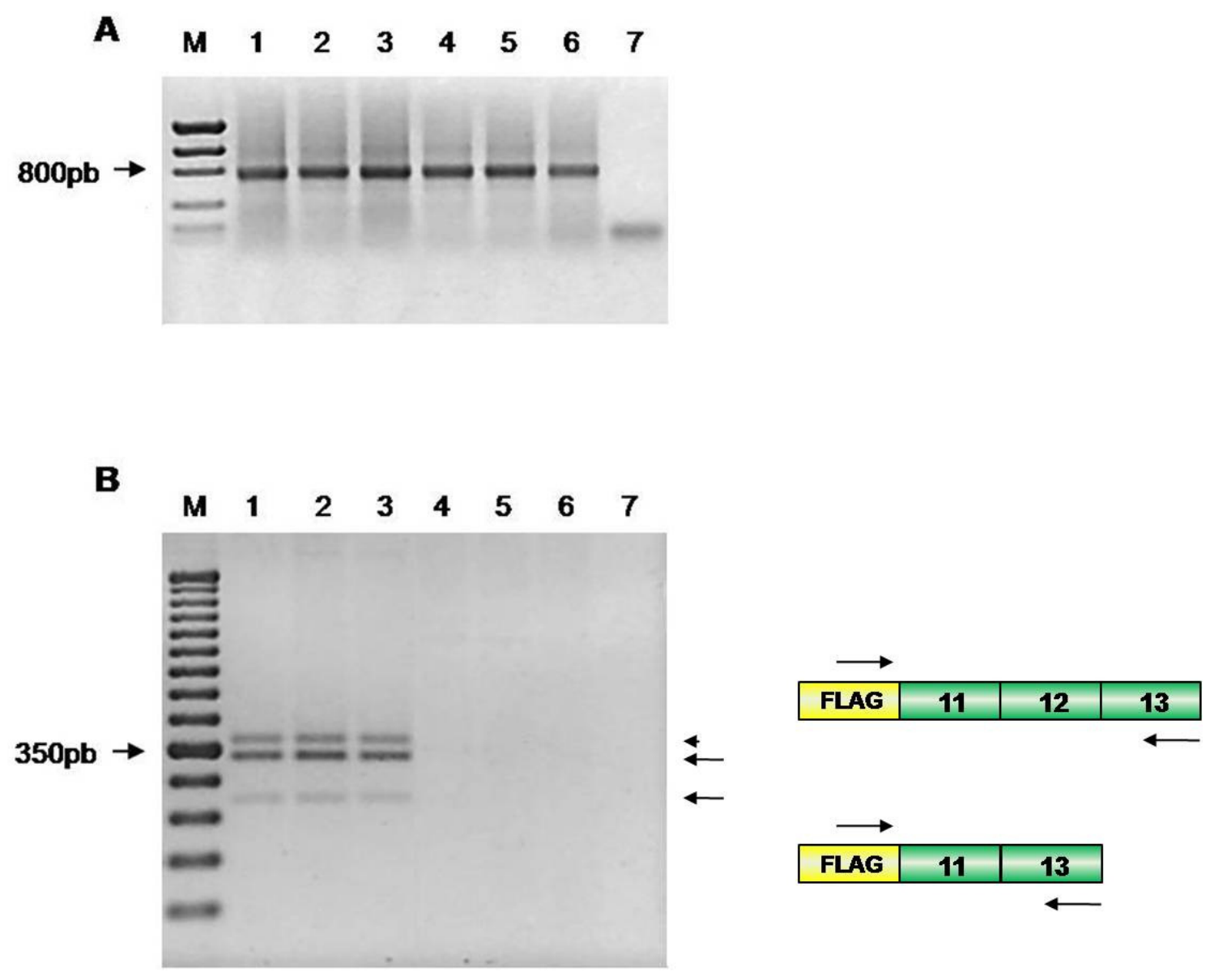

Figura 35: Géis de agarose a $2 \%$ nos quais foram submetidos a eletroforese produtos de PCR amplificados a partir das amostras de CDNA de células C6 transfectadas com vetores recombinantes e não recombinantes. (A). Reação de PCR que utilizou iniciadores específicos para a sequência do gene Fmr1, mostrando presença de transcritos endógenos deste gene nas amostras de cDNA das células recombinantes (1 a 3) e não recombinantes (4 a 6). (7) Controle negativo. (M) Padrão de tamanho e peso molecular Low Mass DNA Ladder, cuja banda de tamanho de 800pb está indicada.

(B). Reação de PCR com iniciadores específicos para os transcritos de vetor pcDNA3.1 recombinante, usando cDNA de células C6 transfectadas com clones recombinantes (1 a 3) e não recombinantes (4 a 6). (7) Controle negativo. (M) Padrão de tamanho e peso molecular 50bp Mass Ladder, cuja banda de 350pb está indicada. As setas indicam bandas de tamanho esperado para transcritos com e sem o éxon 12, conforme diagrama à esquerda da figura, no qual as setas representam os iniciadores. Ponta de seta indica banda aparentemente inespecífica. Após eletroforese, os géis foram corados com brometo de etídio e observados à luz ultravioleta. 


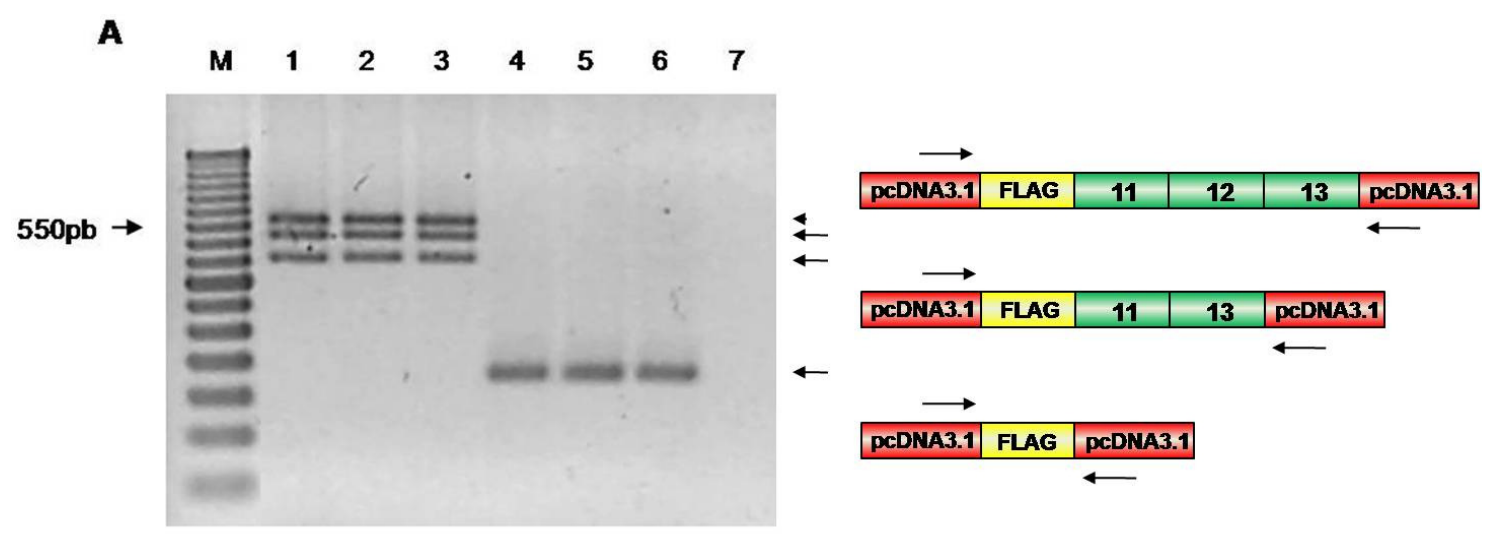

B

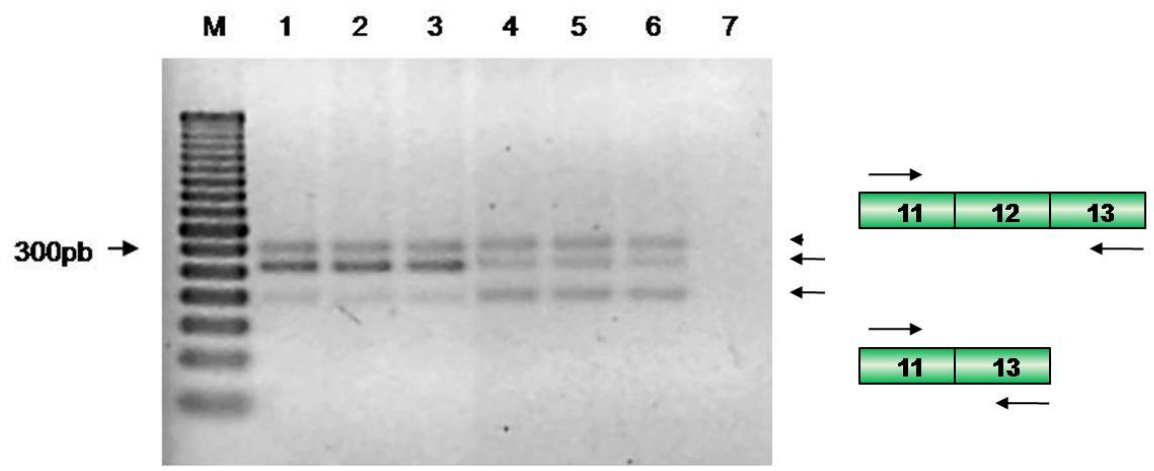

Figura 36: Géis de agarose a $2 \%$ nos quais foram submetidos a eletroforese produtos de PCR amplificados a partir das amostras de cDNA de células C6 transfectadas com vetores recombinantes e não recombinantes. (A). Reação de PCR que utilizou iniciadores específicos para a sequência do vetor pcDNA3.1. Células transfectadas com vetores recombinantes (1 a 3) e não recombinantes (4 a 6). (7) Controle negativo. (M) Padrão de tamanho e peso molecular 50bp Mass Ladder, cuja banda de tamanho 550pb está indicada. As setas indicam bandas de tamanho esperado para transcritos com e sem o éxon 12, conforme diagrama à esquerda da figura, no qual as setas representam os iniciadores. Ponta de seta indica banda aparentemente inespecífica

(B). Reação de PCR com iniciadores específicos para a sequência do Fmr1 incluída no vetor. Células C6 transfectadas com vetores recombinantes (1 a 3) e não recombinantes (4 a 6). (7) Controle negativo. (M) Padrão de tamanho e peso molecular 50bp Mass Ladder, cuja banda de $300 \mathrm{pb}$ está indicada. As setas indicam bandas de tamanho esperado para transcritos com e sem o éxon 12, conforme diagrama à esquerda da figura, no qual as setas representam os iniciadores. Ponta de seta indica banda aparentemente inespecífica. Após eletroforese os géis foram corados com brometo de etídio e observados à luz ultravioleta. 


\section{III.III Deleções do clone gFX11X13}

O clone original, gFX11X13, foi deletado na região inicial do íntron 12 do Fmr1 para a criação do clone $\mathrm{gFX} 11 \mathrm{X} 13 \Delta \mathrm{i} 12$. este clone foi originalmente produzido em bactérias (Fig. 37) e posteriormente transfectado em células C6, cuja expressão foi analisada por RT-PCR (Fig. 39).

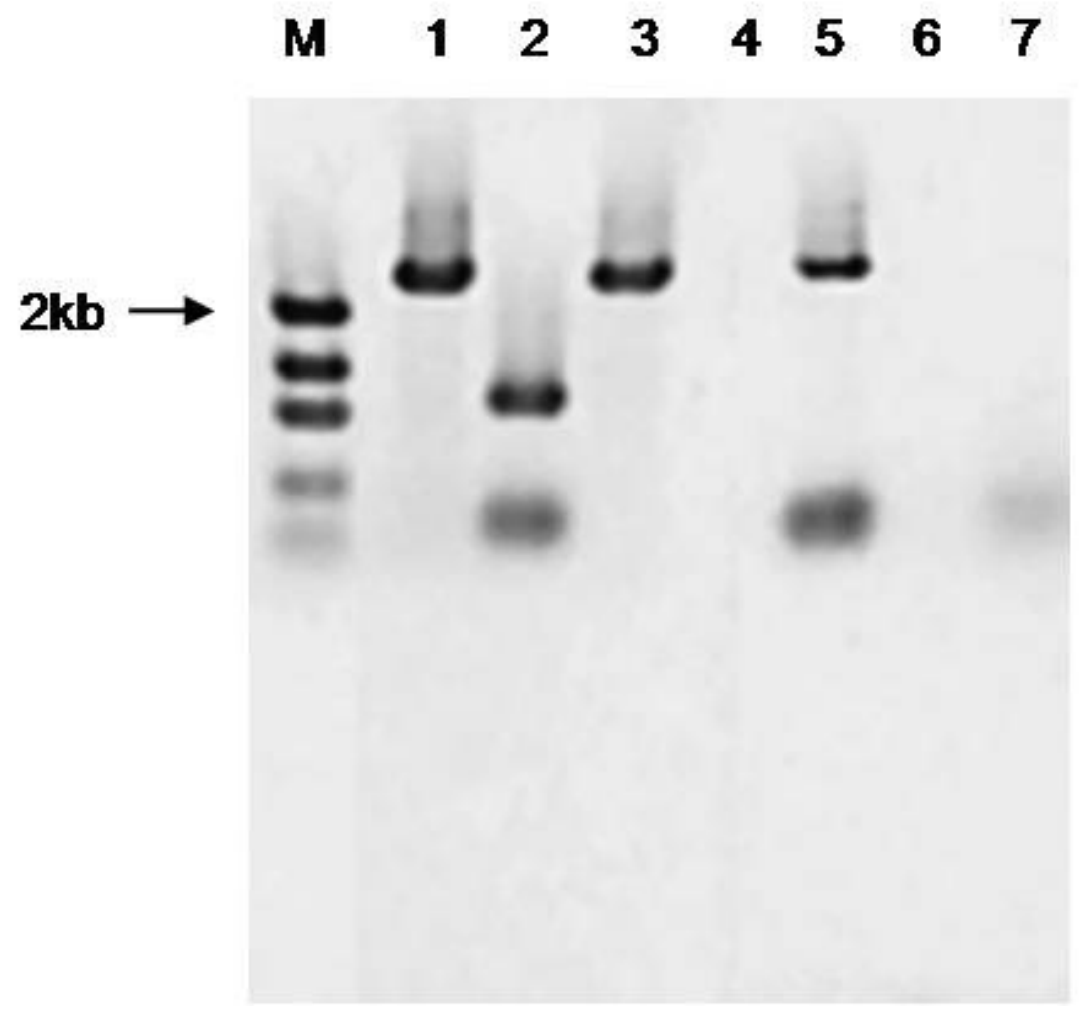

Figura 37: Gel de agarose a 0,8\% no qual foram sumetidos a eletroforese produtos de PCR amplificados a partir das colônias de bactéria da transformação referente a construção deletada. Cerca de metade das colônias (1, 3 e 5) triadas apresentaram o produto de amplificação com o tamanho esperado ( 2300pb). (M) Padrão de tamanho e peso molecular Low Mass DNA Ladder, cuja banda de $2 \mathrm{~kb}$ está indicada. Após eletroforese o gel foi corado com brometo de etídio e observado à luz ultravioleta. 
O seqüenciamento deste clone mostrou que o porção do íntron 12 foi removida assim como esperado e que nenhuma alteração de nucleotídeo adicional foi introduzida na seqüência (Fig. 39).

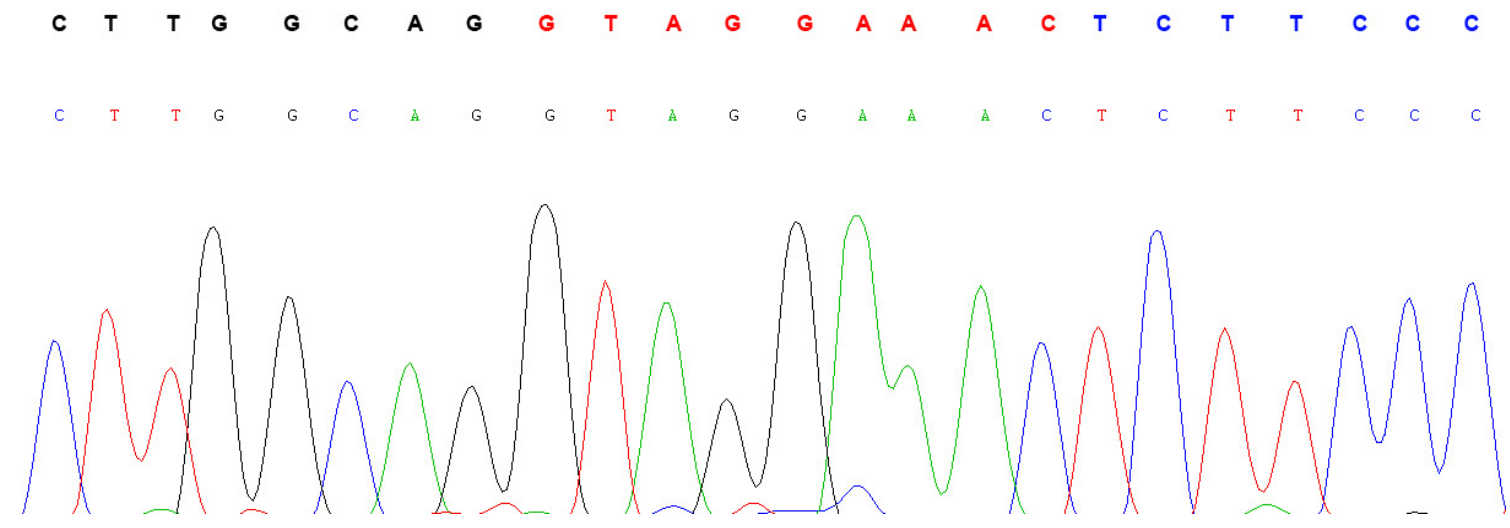

Figura 38: Exemplo de parte do seqüenciamento realizado para averiguar a sequência do clone contendo o segmento genômico de Fmr1 ligado ao vetor pcDNA3 contendo deleção no início do íntron 12. O eletroferograma mostra seqüenciamento realizado com iniciador específico para o inserto, alinhado a sequência de referência da construção acima. Na sequência de referência os caracteres em preto representam o final da sequência do éxon 12, enquanto os caracteres em vermelho representam o início do íntron 12 antes da região deletada e os caracteres em azul representam a sequência ainda do íntron 12 após o segmento deletado. 
O estudo da expressão do clone gFX11X13 $\mathrm{i} 12$ foi realizado com os iniciadores específicos para a sequência FLAG e para o éxon 13, assim como foi feito para o clone gFX11X13 (Fig. 35 B). A comparação da expressão destes dois clones mostrou o mesmo padrão de bandas, porém para o clone gFX11X13 $\Delta \mathrm{i} 12$ observamos diminuição da intensidade das bandas referentes a variante que inclui o éxon 12 e aumento da intensidade das bandas referentes a variante que exclui este éxon do Fmr1;

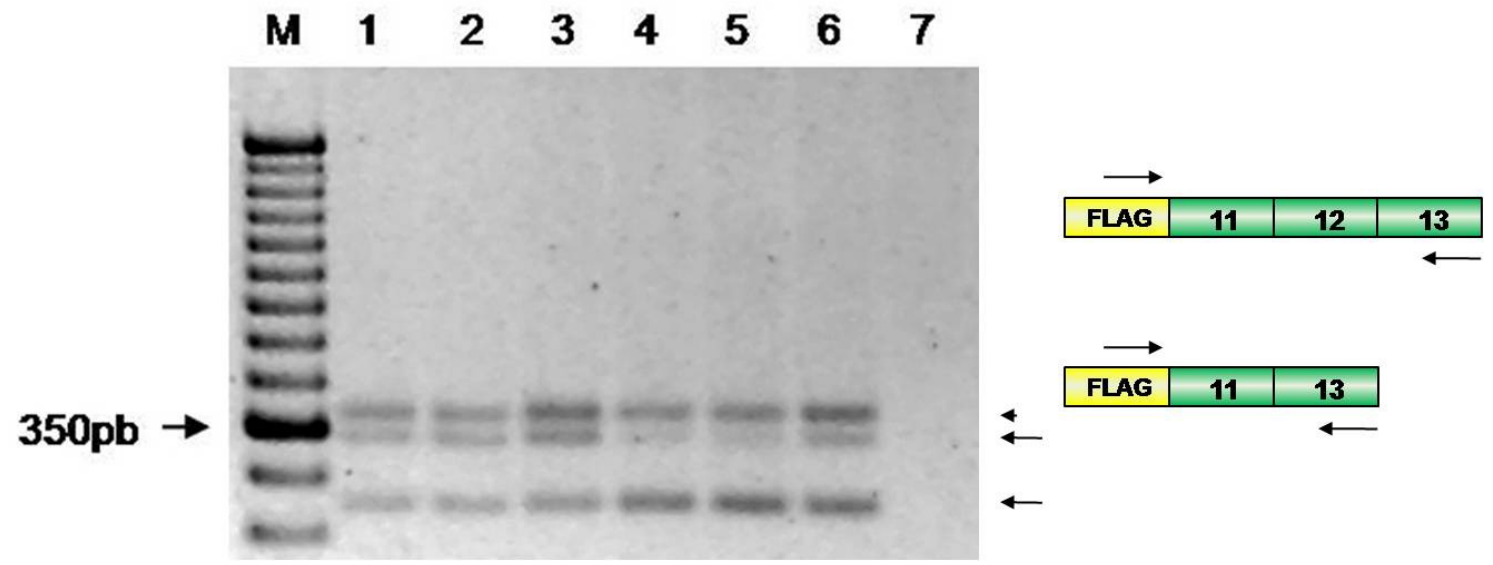

Figura 39: Gel de agarose a $2 \%$ no qual foram sumetidos a eletroforese produtos de PCR amplificados com iniciadores específicos para os transcritos do vetor pcDNA3.1. Amostras de cDNA de células de mamífero transfectadas com o clone não deletado (gFX11X13) (1 a 3) e com o clone mutante (gFX11X13d) (4 a 6). (7) Controle negativo. (M) Padrão de tamanho e peso molecular 50bp Mass Ladder, cuja banda de tamanho 350pb está indicada. As setas indicam bandas de tamanho esperado para transcritos com e sem o éxon 12, conforme diagrama à esquerda da figura, no qual as setas representam os iniciadores. Ponta de seta indica banda aparentemente inespecífica. Após eletroforese os géis foram corados com brometo de etídio e observado à luz ultravioleta. 


\section{DISCUSSÃO}

O hnRNA de grande parte dos genes de mamíferos apresenta diversos sítios passíveis de participarem de splicing alternativo, tendo potencial para gerar um enorme número de transcritos a partir de um gene. Uma questão que se apresenta é qual a proporção destas variantes irá de fato ter repercussão funcional. A geração destas variantes pode ter diferentes consequências, como demonstrado (Blencowe, 2006).

O desenvolvimento, em nosso laboratório, de um anticorpo policlonal que reconhece as isoformas da FMRP contendo o segmento codificado pelo éxon 12 do Fmr1 revelou que estas isoformas são expressas no SNC do rato (dados não publicados), o que justifica o estudo da expressão semi-quantitativa e do mecanismo de regulação da inclusão deste éxon.

Neste trabalho, mostramos por RT-PCR em tempo real que a inclusão do éxon 12 do Fmr1 é regulada no córtex cerebral de rato entre os dias E19 e P2. Estes dados indicam que o córtex cerebral frontal de ratos, no segundo dia pós-natal, é uma boa fonte de proteínas ativadoras da inclusão do éxon 12 no RNAm do Fmr1 e que este tecido pode, por isso, ser usado no futuro na busca por esses fatores em trans reguladores do splicing do éxon 12 do Fmr1. Nas análises, normalizada e não normalizada, da expressão do éxon 12 do Fmr1 no córtex cerebral frontal, não se observou aumento do conjunto das mensagens do Fmr1 concomitante ao aumento significativo da inclusão do éxon 12. Isto mostra que esta diferença de expressão do éxon 12 não é um reflexo do aumento transcricional do Fmr1. Será interessante investigar se os níveis de inclusão do éxon 12 se mantêm altos no RNAm do Fmr1 ao longo do desenvolvimento pós-natal.

Os mecanismos de regulação da meia-vida do RNAm são complexos e vários são os fatores determinando o destino desta molécula entre sua degradação ou permanência citoplasmática, na qual há ainda a definição entre atividade ou silenciamento traducional (Lejeune \& Maquat, 2005). Um aspecto a ser avaliado é se 
os níveis de transcritos do Fmr1 contendo o éxon 12 se correlacionam aos níveis de expressão de isoformas da FMRP contendo o segmento codificado pelo éxon 12, no córtex cerebral frontal em P2.

No hipocampo dos animais testados observamos um aumento na expressão geral do Fmr1 entre E19 e P2. Observou-se paralelamente, no mesmo período e tecido, uma tendência à exclusão do éxon 12. Estes dados gerados para o hipocampo não puderam ser comparados aos controles internos usualmente empregados neste tipo de estudo. $O$ gene da Ciclofilina $A$ de rato foi selecionado entre outros testados (gliceraldeído 3-fosfato desidrogenase, Gapdh, Actina beta, Actb) por apresentar menor variabilidade de expressão, mas apresentou posteriormente diferença de expressão no hipocampo entre as duas idades (Fig. 14), distorcendo os dados do Fmr1 quando normalizados. A escolha de um gene normalizador é fundamental à reprodutibilidade e confiabilidade dos dados de PCR em tempo real. A expressão de um bom gene normalizador não deve variar entre as amostras. Não encontramos estudos relacionando a expressão do gene da Ciclofilina A no hipocampo, neste período do desenvolvimento. É possível que o gene da Ciclofilina A tenha expressão variável, ainda não demonstrada, em hipocampo embrionário, o que não o classifica como um bom normalizador em estudos de RT-PCR em tempo real nestas condições, embora seja muito usado em outras idades. Desta forma, no nosso estudo, os cDNAs dos indivíduos poderiam ser submetidos a análises com novos controles internos para confirmação dos resultados ou avaliados sem normalização. Mantivemos nossas análises sem normalização basicamente por três razões. Em primeiro lugar, os dados do conjunto de transcritos do Fmr1 no hipocampo correlacionaram-se bem com outros já relatados (Hinds et al., 1993; Verkerk ET al., 1993; Nimchinsky et al., 2001). Em segundo lugar, a significância dos dados em tecidos como córtex cerebral se manteve, com ou sem normalização e; finalmente, sendo a FMRP um regulador traducional envolvido com morfologia de espinhas dendríticas por remodelamento de actina (Reeve et al., 2005), muitos genes de expressão constitutiva comumente utilizados 
como o da Actina beta, podem, neste caso, ser regulados e, por isso, inadequados, tornando difícil a busca pelo gene normalizador ideal.

Córtex cerebral e hipocampo são estruturas encefálicas mais comumente utilizadas na análise do Fmr1, dadas a alta expressão deste gene nestes tecidos e sua importância funcional no aprendizado, cuja disfunção no início do desenvolvimento é o retardo mental (Hinds et al., 1993). O estudo da expressão do Fmr1 no córtex cerebral e hipocampo no final do período embrionário e início do desenvolvimento pós-natal é importante, pois esta é uma fase em que se observa maior disfunção de plasticidade de espinhas dendríticas no córtex cerebral do camundongo nocaute do Fmr1 (Nimchinsky et al., 2001). O remodelamento de espinhas dendríticas em neurônios piramidais do córtex cerebral foi proposto como a base celular da aprendizagem e memória. Neste sistema, o desenvolvimento pós-natal precoce, anormal é um componente fundamental para estabelecimento de desordens como o retardo mental (Desai et al., 2006). No entanto, o amadurecimento de espinhas dendríticas segue um curso próprio a cada região encefálica (Harris et al., 1992). Acredita-se que a deficiência da FMRP tenha consequências neuro-anatômicas também específicas a cada estrutura do SNC, como demonstrado por Grossman e cols (2006) pela morfologia distinta de espinhas dendríticas entre as duas estruturas encefálicas do camundongo nocaute do Fmr1. Do ponto de vista fisiológico, foi também sugerido que estes camundongos tenham disfunções moleculares não congruentes, como depressão sináptica a longo termo (LTD) aumentada no hipocampo e potenciação sináptica a longo termo (LTP) diminuída no córtex cerebral (Huber et al., 2002; Li et al., 2002; Larson et al, 2005). LTP é uma forma duradoura de plasticidade sináptica relacionada à formação de memória, que se opõe à LTD. Apesar de estes resultados terem basicamente o mesmo efeito, interferindo na formação de memória, seus aspectos moleculares diferem. Diante destas observações da literatura científica e dos nossos resultados da expressão do éxon 12 do Fmr1 em P2, de maneira antagônica entre córtex cerebral e hipocampo, avaliamos que uma alternativa a estudos 
funcionais sobre as isoformas da FMRP que expressam este éxon possa ser relacionada aos mecanismos de eliminação sináptica no córtex cerebral. O segmento da FMRP codificado pelos éxons 10 ao 12 do Fmr1 parece relacionar-se à formação de uma alça variável na estrutura do segundo domínio KH da FMRP (Valverde ET al., 2007). Assim, é possível que a variação do comprimento desta alça variável da FMRP, pela inclusão ou exclusão do éxon 12 nos transcritos do Fmr1, modifique o padrão de ligação da FMRP aos RNAs-alvo, uma hipótese a ser testada.

A taxa de inclusão do éxon 12 no cerebelo, para o qual só dispúnhamos de amostras em P2, mostrou-se semelhante à da maioria observada, exceto do córtex cerebral em P2. Hinds e cols (1993) revelaram por hibridação in situ de tecidos de camundongo adulto que o Fmr1 tem expressão relativamente alta nas camadas granulares do córtex cerebelar e hipocampo, seguido do córtex cerebral. Homens portadores de pré-mutação do FMR1 podem desenvolver FXTAS, cujas manifestações compreendem ataxia, um sinal clínico de disfunção cerebelar (Greco et al, 2006). Desta forma, a expressão do Fmr1 no cerebelo do animal adulto deve ser examinada futuramente, procurando-se relacioná-la aos déficits observados nos pacientes. Embora mais negligenciada, a contribuição do cerebelo no aprendizado relacionado à FMRP foi sugerida pela observação de déficits de aprendizagem motora em camundongos nocautes do Fmr1 (Koekkoek et al., 2005).

O tamanho sub-ótimo de éxons, abaixo de $130 \mathrm{pb}$, é um fator que tem sido relacionado à mais alta frequência de splicing alternativo e uso de elementos acessórios reguladores do splicing (Carlo et al, 1996). Embora esta tenha sido uma possibilidade levantada durante o trabalho, a diferença de inclusão do éxon 12 entre as três estruturas do SNC sugere uma regulação fina deste splicing com relevância funcional no córtex frontal, o que não pode ser explicado exclusivamente pelo tamanho sub-ótimo deste éxon.

A produção do mini-gene gFX11X13, que contém a sequência genômica do início do éxon 11 ao final do éxon 13 do Fmr1 de rato, permitiu o estudo do padrão de 
splicing do éxon 12 superexpresso em células do SNC desta mesma espécie, C6, proveniente de glioma de rato. A análise por RT-PCR dos transcritos produzidos nestas células transfectadas, utilizando iniciadores específicos para o vetor, mostrou duas bandas, cujos tamanhos correspondem ao esperado para RNAm expressos a partir desta construção, incluindo (323pb) e excluindo (260pb) o éxon 12, mais uma banda de origem não determinada (Fig. 35 B). Este produto, de tamanho maior do que a variante incluindo o éxon 12, não é observado em células não recombinantes neste experimento com iniciadores específicos para o vetor, porém está presente quando se usa iniciadores que hibridam nos éxons 11 e 13 do gene Fmr1. O terceiro produto de PCR foi também observado na amplificação de transcritos endógenos da célula, descartando erros de emparelhamento de iniciadores ou influência da sequência do vetor no processo de splicing. Embora, as soluções tenham sido renovadas a partir dos estoques, não podemos descartar que tenha havido contaminação. Como esta terceira banda é maior do que as outras duas esperadas, uma possibilidade seria a inclusão de um segmento intrônico curto por alteração de sequência, considerando-o como um quarto éxon, não identificado. No entanto, o splicing alternativo do Fmr1 já foi amplamente investigado por RT-PCR e tal variante não foi identificada. Além disso, a sequência das duas fitas não identificou nenhuma alteração de sequência. Pode ainda constituir uma alteração de splicing produzida pela linhagem da C6 que, além de ser imortalizada, é proveniente de um tumor, contendo certamente várias alterações genômicas. O seqüenciamento deste produto de PCR esclarecerá sua natureza.

A razão da escolha do organismo Rattus novergicus como fonte de material biológico para experimentos em nosso laboratório foi sua fácil obtenção, ter o gene Fmr1 conservado, e encéfalo consideravelmente maior do que o de camundongo para utilização em experimentos de culturas celulares e ensaios protéicos, facilitando sua dissecção. A expressão de mini-genes depende logicamente do organismo e tipo celular utilizado, uma vez que o elemento em cis só será identificado se a proteína expressa naquela célula, elemento em trans, se ligar a ele (Cooper, 2005). Um tipo 
celular adequado para ser aplicado a este trabalho são neurônios corticais de rato, a partir de culturas primárias, uma vez que estas células são do organismo e tecido de interesse e não são transformadas. No entanto, a obtenção de culturas primárias, puras, de neurônios não é viável e o índice de transfecção destas células é muito baixo e pouco reprodutível. Desta forma, escolhemos as células C6 que são derivadas de glioma de rato, nas quais obtivemos um padrão preferencial de inclusão do éxon 12 do Fmr1. Uma alternativa é a utilização da linhagem imortalizada PC12, originária de feocromocitoma de rato, que permite certa diferenciação neuronal in vitro e apresenta índices de transfecção um pouco mais elevados. De todo modo, mesmo tipos celulares não relacionados ao modelo biológico, podem expressar os elementos em trans e fornecer resultados. Consideramos ainda o uso de um novo tipo celular nos experimentos, procurando identificar também um padrão de exclusão preferencial para prosseguir em paralelo rumo à identificação de elementos silenciadores e seus repressores do splicing do éxon 12 do Fmr1.

As análises in silico de buscas por elementos regulatórios em cis do splicing do éxon 12, realizadas para humanos, camundongo e rato, mostraram alguma similaridade entre os resultados para estas três espécies. As primeiras 200 bases do íntron 12 apresentaram boa densidade de elementos candidatos a regular o splicing, principalmente ISE (Fig. 26), padrão semelhante ao observado para as mesmas análises realizadas com a sequência murina (Fig. 28). Esta região tem alta similaridade entre as sequências de DNA do íntron 12, humano, murino e de rato (dados não mostrados), o que constitui um fator importante a ser considerado na busca por elementos reguladores do splicing, uma vez que sequências similares em ou próximas a éxons que sofrem splicing alternativo, de modo conservado, têm mais alta probabilidade de abrigar acentuadores e silenciadores de splicing.

De acordo com o resultado obtido in vitro com o mini-gene, inclusão preferencial do éxon 12 do Fmr1, esperamos com a deleção do clone original identificar sequências abrigando acentuadores do splicing. Deleção da base seis a 169 do íntron 12 foi 
realizada com sucesso, gerando o clone gFX11X13山i12, cujo padrão de expressão, em células C6 com ele transfectadas, ficou invertido, passando a apresentar exclusão preferencial do éxon 12 do Fmr1. A ausência de um padrão absoluto de inclusão ou exclusão exônica nas células transfectadas com um dos dois clones, gFX11X13 ou gFX11X13 $\Delta$ i12, deve ser um reflexo do efeito combinatório do splicing.

Observando a sequência deletada (bases 9 a 169 do intron 12, Figs 26 e 28), percebe-se que, apesar da alta similaridade entre as sequências dos três organismos nesta região, não há tanta sobreposição dos resultados in silico. O resultado coincidente mais evidente são os elementos adjacentes, deslocados, TTCCCC e CCCCTT, por volta da base 50 deste íntron que, no transcrito equivale a UUCCCC e CCCCUU. De acordo com a Tabela 1, observa-se que a sequência desses elementos não se assemelha muito aos consensos, podendo constituir um elemento degenerado, rico nas bases pirimídicas U e C. Temos hoje estes elementos UUCCCC e CCCCUU como nossos candidatos a sofrerem mutagênese dirigida e serem então testados no mesmo tipo de ensaio in vitro aqui demonstrado.

A busca por elementos regulatórios no éxon 12 do Fmr1 identificou, em humanos e camundongos, candidatos a ESE na região central do éxon (entre os nucleotídeos 30 e 50) com as ferramentas usadas. Pela alta concordância dos resultados de ESE in silico, uma deleção no mini-gene compreendendo os elementos identificados é desejável, mas tecnicamente difícil pela baixa disponibilidade de sítios de restrição únicos nesta região do mini-gene. Outra alternativa é a realização direta da mutagênese dirigida.

A falta de identificação in silico de alguns tipos de elementos regulatórios do splicing, específicos para o transcriptoma de rato, deve-se ao fato de haver menos estudos neste sentido neste organismo. A maior disponibilidade de dados experimentais tende a enriquecer os bancos de dados, disponibilizando dados in silico para várias espécies e aumento da correlação de seus resultados. 


\section{REFERÊNCIAS BIBLIOGRÁFICAS}

Abelson, J. (1979). RNA processing and the intervening sequence problem. Annu Rev Biochem 48: 1035-69.

Abitbol, M., C. Menini, A. L. Delezoide, T. Rhyner, M. Vekemans and J. Mallet (1993). Nucleus basalis magnocellularis and hippocampus are the major sites of FMR-1 expression in the human fetal brain. Nat Genet 4(2): 147-53.

Abril, J. F., R. Castelo and R. Guigo (2005). Comparison of splice sites in mammals and chicken. Genome Res 15(1): 111-9.

Adinolfi, S., A. Ramos, S. R. Martin, F. Dal Piaz, P. Pucci, B. Bardoni, J. L. Mandel and A. Pastore (2003). The $\mathrm{N}$-terminus of the fragile $\mathrm{X}$ mental retardation protein contains a novel domain involved in dimerization and RNA binding. Biochemistry 42(35): 10437-44.

Ahn, S. H., M. Kim and S. Buratowski (2004). Phosphorylation of serine 2 within the RNA polymerase II C-terminal domain couples transcription and 3' end processing. Mol Cell 13(1): 67-76.

Alberts, B. J., A. Lewis, J. Raff, M. Roberts, K. Walter, P (2002). Molecular Biology of the Cell, Fourth Edition, Garland.

Aloni, Y., R. Dhar, O. Laub, M. Horowitz and G. Khoury (1977). Novel mechanism for RNA maturation: the leader sequences of simian virus $40 \mathrm{mRNA}$ are not transcribed adjacent to the coding sequences. Proc Natl Acad Sci U S A 74(9): 3686-90.

Alt, F. W., A. L. Bothwell, M. Knapp, E. Siden, E. Mather, M. Koshland and D. Baltimore (1980). Synthesis of secreted and membrane-bound immunoglobulin mu heavy chains is directed by mRNAs that differ at their 3' ends. Cell 20(2): 293-301.

Amara, S. G., V. Jonas, M. G. Rosenfeld, E. S. Ong and R. M. Evans (1982). Alternative RNA processing in calcitonin gene expression generates mRNAs encoding different polypeptide products. Nature 298(5871): 240-4.

Amrani, N., M. S. Sachs and A. Jacobson (2006). Early nonsense: mRNA decay solves a translational problem. Nat Rev Mol Cell Biol 7(6): 415-25.

Antar, L. N., R. Afroz, J. B. Dictenberg, R. C. Carroll and G. J. Bassell (2004). Metabotropic glutamate receptor activation regulates fragile $\mathrm{x}$ mental retardation protein and FMR1 mRNA localization differentially in dendrites and at synapses. J Neurosci 24(11): 2648-55.

Antar, L. N., J. B. Dictenberg, M. Plociniak, R. Afroz and G. J. Bassell (2005). Localization of FMRP-associated mRNA granules and requirement of microtubules for activity-dependent trafficking in hippocampal neurons. Genes Brain Behav 4(6): 350-9.

Apweiler, R., M. J. Martin, C. O'Donovan and M. Pruess (2003). Managing core resources for genomics and proteomics. Pharmacogenomics 4(3): 343-50.

Artamonova, II and M. S. Gelfand (2007). Comparative genomics and evolution of alternative splicing: the pessimists' science. Chem Rev 107(8): 3407-30.

Ashley, C. T., J. S. Sutcliffe, C. B. Kunst, H. A. Leiner, E. E. Eichler, D. L. Nelson and S. T. Warren (1993). Human and murine FMR-1: alternative splicing and translational initiation downstream of the CGG-repeat. Nat Genet 4(3): 244-51.

Ashley, C. T., Jr., K. D. Wilkinson, D. Reines and S. T. Warren (1993). FMR1 protein: conserved RNP family domains and selective RNA binding. Science 262(5133): 563-6.

Ast, G. (2004). How did alternative splicing evolve? Nat Rev Genet 5(10): 773-82.

Baker, B. S. (1989). Sex in flies: the splice of life. Nature 340(6234): 521-4.

Bakker, C. E., Y. de Diego Otero, C. Bontekoe, P. Raghoe, T. Luteijn, A. T. Hoogeveen, B. A. Oostra and R. Willemsen (2000). Immunocytochemical and biochemical characterization of FMRP, FXR1P, and FXR2P in the mouse. Exp Cell Res 258(1): 162-70. 
Barbee, S. A., P. S. Estes, A. M. Cziko, J. Hillebrand, R. A. Luedeman, J. M. Coller, N. Johnson, I. C. Howlett, C. Geng, R. Ueda, et al. (2006). Staufen- and FMRPcontaining neuronal RNPs are structurally and functionally related to somatic $P$ bodies. Neuron 52(6): 997-1009.

Bardoni, B., L. Davidovic, M. Bensaid and E. W. Khandjian (2006). The fragile X syndrome: exploring its molecular basis and seeking a treatment. Expert Rev Mol Med 8(8): 1-16.

Bardoni, B. and J. L. Mandel (2002). Advances in understanding of fragile $X$ pathogenesis and FMRP function, and in identification of $X$ linked mental retardation genes. Curr Opin Genet Dev 12(3): 284-93.

Bardoni, B., J. L. Mandel and G. S. Fisch (2000). FMR1 gene and fragile X syndrome. Am J Med Genet 97(2): 153-63.

Bardoni, B., A. Schenck and J. L. Mandel (2001). The Fragile X mental retardation protein. Brain Res Bull 56(3-4): 375-82.

Bardoni, B., A. Sittler, Y. Shen and J. L. Mandel (1997). Analysis of domains affecting intracellular localization of the FMRP protein. Neurobiol Dis 4(5): 329-36.

Baxevanis, A. D. (2003). Using Genomic Databases for Sequence-Based Biological discovery. Molecular Medicine 9(12): 185-192.

Bell, M. V., M. C. Hirst, Y. Nakahori, R. N. MacKinnon, A. Roche, T. J. Flint, P. A. Jacobs, N. Tommerup, L. Tranebjaerg, U. Froster-Iskenius, et al. (1991). Physical mapping across the fragile $\mathrm{X}$ : hypermethylation and clinical expression of the fragile $X$ syndrome. Cell 64(4): 861-6.

Bentley, D. (1999). Coupling RNA polymerase II transcription with pre-mRNA processing. Curr Opin Cell Biol 11(3): 347-51.

Berezikov, E., W. J. Chung, J. Willis, E. Cuppen and E. C. Lai (2007). Mammalian mirtron genes. Mol Cell 28(2): 328-36.

Berget, S. M., C. Moore and P. A. Sharp (1977). Spliced segments at the 5' terminus of adenovirus 2 late mRNA. Proc Natl Acad Sci U S A 74(8): 3171-5.

Berget, S. M. and B. L. Robberson (1986). U1, U2, and U4/U6 small nuclear ribonucleoproteins are required for in vitro splicing but not polyadenylation. Cell 46(5): 691-6.

Berglund, J. A., N. Abovich and M. Rosbash (1998). A cooperative interaction between U2AF65 and mBBP/SF1 facilitates branchpoint region recognition. Genes Dev 12(6): 858-67.

Berglund, J. A., K. Chua, N. Abovich, R. Reed and M. Rosbash (1997). The splicing factor BBP interacts specifically with the pre-mRNA branchpoint sequence UACUAAC. Cell 89(5): 781-7.

Berglund, J. A., M. L. Fleming and M. Rosbash (1998). The KH domain of the branchpoint sequence binding protein determines specificity for the pre-mRNA branchpoint sequence. Rna 4(8): 998-1006.

Berry-Kravis, E., L. Abrams, S. M. Coffey, D. A. Hall, C. Greco, L. W. Gane, J. Grigsby, J. A. Bourgeois, B. Finucane, S. Jacquemont, et al. (2007). Fragile Xassociated tremor/ataxia syndrome: clinical features, genetics, and testing guidelines. Mov Disord 22(14): 2018-30, quiz 2140.

Bingham, J. L., P. E. Carrigan, L. J. Miller and S. Srinivasan (2008). Extent and diversity of human alternative splicing established by complementary database annotation and microarray analysis. Omics 12(1): 83-92.

Birney, E., T. D. Andrews, P. Bevan, M. Caccamo, Y. Chen, L. Clarke, G. Coates, J. Cuff, V. Curwen, T. Cutts, et al. (2004). An overview of Ensembl. Genome Res 14(5): 925-8.

Birney, E., J. A. Stamatoyannopoulos, A. Dutta, R. Guigo, T. R. Gingeras, E. H. Margulies, Z. Weng, M. Snyder, E. T. Dermitzakis, R. E. Thurman, et al. (2007). Identification and analysis of functional elements in $1 \%$ of the human genome by the ENCODE pilot project. Nature 447(7146): 799-816.

Birzele, F., G. Csaba and R. Zimmer (2008). Alternative splicing and protein structure 
evolution. Nucleic Acids Res 36(2): 550-8.

Black, D. L. (2003). Mechanisms of alternative pre-messenger RNA splicing. Annu Rev Biochem 72: 291-336.

Black, D. L. and J. A. Steitz (1986). Pre-mRNA splicing in vitro requires intact U4/U6 small nuclear ribonucleoprotein. Cell 46(5): 697-704.

Blake, C. C. (1978). X-ray sequencing of proteins by refinement. Nature 274(5670): 420-1.

Blake, C. C. (1979). Exons encode protein functional units. Nature 277(5698): 598.

Blanchard, J. M., J. Weber, W. Jelinek and J. E. Darnell (1978). In vitro RNA-RNA splicing in adenovirus 2 mRNA formation. Proc Natl Acad Sci U S A 75(11): 5344-8.

Blencowe, B. J. (2005). Splicing on the brain. Nat Genet 37(8): 796-7.

Blencowe, B. J. (2006). Alternative splicing: new insights from global analyses. Cell 126(1): 37-47.

Bono, H. and Y. Okazaki (2002). Functional transcriptomes: comparative analysis of biological pathways and processes in eukaryotes to infer genetic networks among transcripts. Curr Opin Struct Biol 12(3): 355-61.

Bourquin, J. P., I. Stagljar, P. Meier, P. Moosmann, J. Silke, T. Baechi, O. Georgiev and W. Schaffner (1997). A serine/arginine-rich nuclear matrix cyclophilin interacts with the C-terminal domain of RNA polymerase II. Nucleic Acids Res 25(11): 2055-61.

Brack, C. and S. Tonegawa (1977). Variable and constant parts of the immunoglobulin light chain gene of a mouse myeloma cell are 1250 nontranslated bases apart. Proc Natl Acad Sci U S A 74(12): 5652-6.

Breathnach, R., J. L. Mandel and P. Chambon (1977). Ovalbumin gene is split in chicken DNA. Nature 270(5635): 314-9.

Brett, D., J. Hanke, G. Lehmann, S. Haase, S. Delbruck, S. Krueger, J. Reich and P. Bork (2000). EST comparison indicates $38 \%$ of human mRNAs contain possible alternative splice forms. FEBS Lett 474(1): 83-6.

Brett, D., H. Pospisil, J. Valcarcel, J. Reich and P. Bork (2002). Alternative splicing and genome complexity. Nat Genet 30(1): 29-30.

Bringmann, P. and R. Luhrmann (1986). Purification of the individual snRNPs U1, U2, U5 and U4/U6 from HeLa cells and characterization of their protein constituents. Embo J 5(13): 3509-16.

Bringmann, P., R. Reuter, J. Rinke, B. Appel, R. Bald and R. Luhrmann (1983). 5'terminal caps of snRNAs are accessible for reaction with 2,2,7trimethylguanosine-specific antibody in intact snRNPs. J Biol Chem 258(5): 2745-7.

Bringmann, P., J. Rinke, B. Appel, R. Reuter and R. Luhrmann (1983). Purification of snRNPs U1, U2, U4, U5 and U6 with 2,2,7-trimethylguanosine-specific antibody and definition of their constituent proteins reacting with anti-Sm and anti(U1)RNP antisera. Embo J 2(7): 1129-35.

Brody, E. and J. Abelson (1985). The "spliceosome": yeast pre-messenger RNA associates with a $40 \mathrm{~S}$ complex in a splicing-dependent reaction. Science 228(4702): 963-7.

Brown, V., P. Jin, S. Ceman, J. C. Darnell, W. T. O'Donnell, S. A. Tenenbaum, X. Jin, Y. Feng, K. D. Wilkinson, J. D. Keene, et al. (2001). Microarray identification of FMRP-associated brain mRNAs and altered mRNA translational profiles in fragile $X$ syndrome. Cell 107(4): 477-87.

Burset, M., I. A. Seledtsov and V. V. Solovyev (2000). Analysis of canonical and noncanonical splice sites in mammalian genomes. Nucleic Acids Res 28(21): 436475.

Burset, M., I. A. Seledtsov and V. V. Solovyev (2001). SpliceDB: database of canonical and non-canonical mammalian splice sites. Nucleic Acids Res 29(1): 255-9.

Calvo, O. and J. L. Manley (2003). Strange bedfellows: polyadenylation factors at the 
promoter. Genes Dev 17(11): 1321-7.

Carlo, T., D. A. Sterner and S. M. Berget (1996). An intron splicing enhancer containing a G-rich repeat facilitates inclusion of a vertebrate micro-exon. Rna 2(4): 34253.

Cartegni, L., S. L. Chew and A. R. Krainer (2002). Listening to silence and understanding nonsense: exonic mutations that affect splicing. Nat Rev Genet 3(4): 285-98.

Cartegni, L., J. Wang, Z. Zhu, M. Q. Zhang and A. R. Krainer (2003). ESEfinder: A web resource to identify exonic splicing enhancers. Nucleic Acids Res 31(13): 356871.

Castren, M., T. Tervonen, V. Karkkainen, S. Heinonen, E. Castren, K. Larsson, C. E. Bakker, B. A. Oostra and K. Akerman (2005). Altered differentiation of neural stem cells in fragile $X$ syndrome. Proc Natl Acad Sci U S A 102(49): 17834-9.

Catterall, J. F., B. W. O'Malley, M. A. Robertson, R. Staden, Y. Tanaka and G. G. Brownlee (1978). Nucleotide sequence homology at 12 intron--exon junctions in the chick ovalbumin gene. Nature 275(5680): 510-3.

Caudy, A. A., M. Myers, G. J. Hannon and S. M. Hammond (2002). Fragile X-related protein and VIG associate with the RNA interference machinery. Genes Dev 16(19): 2491-6.

Cech, T. R. (1986). The generality of self-splicing RNA: relationship to nuclear mRNA splicing. Cell 44(2): 207-10.

Chakalova, L., E. Debrand, J. A. Mitchell, C. S. Osborne and P. Fraser (2005). Replication and transcription: shaping the landscape of the genome. Nat Rev Genet 6(9): 669-77.

Chang, Y. F., J. S. Imam and M. F. Wilkinson (2007). The nonsense-mediated decay RNA surveillance pathway. Annu Rev Biochem 76: 51-74.

Chmiel, N. H., D. C. Rio and J. A. Doudna (2006). Distinct contributions of KH domains to substrate binding affinity of Drosophila P-element somatic inhibitor protein. Rna 12(2): 283-91.

Chow, L. T., R. E. Gelinas, T. R. Broker and R. J. Roberts (1977). An amazing sequence arrangement at the $5^{\prime}$ ends of adenovirus 2 messenger RNA. Cell 12(1): 1-8.

Chow, L. T., J. M. Roberts, J. B. Lewis and T. R. Broker (1977). A map of cytoplasmic RNA transcripts from lytic adenovirus type 2 , determined by electron microscopy of RNA:DNA hybrids. Cell 11(4): 819-36.

Churbanov, A., I. B. Rogozin, J. S. Deogun and H. Ali (2006). Method of predicting splice sites based on signal interactions. Biol Direct 1: 10.

Chusainow, J., P. M. Ajuh, L. Trinkle-Mulcahy, J. E. Sleeman, J. Ellenberg and A. I. Lamond (2005). FRET analyses of the U2AF complex localize the U2AF35/U2AF65 interaction in vivo and reveal a novel self-interaction of U2AF35. Rna 11(8): 1201-14.

Clark, F. and T. A. Thanaraj (2002). Categorization and characterization of transcriptconfirmed constitutively and alternatively spliced introns and exons from human. Hum Mol Genet 11(4): 451-64.

Claverie, J. M. (2001). Gene number. What if there are only 30,000 human genes? Science 291(5507): 1255-7.

Cochrane, G., P. Aldebert, N. Althorpe, M. Andersson, W. Baker, A. Baldwin, K. Bates, S. Bhattacharyya, P. Browne, A. van den Broek, et al. (2006). EMBL Nucleotide Sequence Database: developments in 2005. Nucleic Acids Res 34(Database issue): D10-5.

Cochrane, G., K. Bates, R. Apweiler, Y. Tateno, J. Mashima, T. Kosuge, I. K. Mizrachi, S. Schafer and M. Fetchko (2006). Evidence standards in experimental and inferential INSDC Third Party Annotation data. Omics 10(2): 105-13.

Coffee, B., F. Zhang, S. Ceman, S. T. Warren and D. Reines (2002). Histone modifications depict an aberrantly heterochromatinized FMR1 gene in fragile $x$ 
syndrome. Am J Hum Genet 71(4): 923-32.

Collins, F. S., M. Morgan and A. Patrinos (2003). The Human Genome Project: lessons from large-scale biology. Science 300(5617): 286-90.

Comery, T. A., J. B. Harris, P. J. Willems, B. A. Oostra, S. A. Irwin, I. J. Weiler and W. T. Greenough (1997). Abnormal dendritic spines in fragile X knockout mice: maturation and pruning deficits. Proc Natl Acad Sci U S A 94(10): 5401-4.

Cooper, T. A. (2005). Use of minigene systems to dissect alternative splicing elements. Methods 37(4): 331-40.

Cooper, T. A. and C. P. Ordahl (1989). Nucleotide substitutions within the cardiac troponin T alternative exon disrupt pre-mRNA alternative splicing. Nucleic Acids Res 17(19): 7905-21.

Coutinho-Mansfield, G. C., Y. Xue, Y. Zhang and X. D. Fu (2007). PTB/nPTB switch: a post-transcriptional mechanism for programming neuronal differentiation. Genes Dev 21(13): 1573-7.

Crick, F. (1979). Split genes and RNA splicing. Science 204(4390): 264-71.

Croft, L., S. Schandorff, F. Clark, K. Burrage, P. Arctander and J. S. Mattick (2000). ISIS, the intron information system, reveals the high frequency of alternative splicing in the human genome. Nat Genet 24(4): 340-1.

Cummings, C. J. and H. Y. Zoghbi (2000). Fourteen and counting: unraveling trinucleotide repeat diseases. Hum Mol Genet 9(6): 909-16.

Custodio, N., M. Antoniou and M. Carmo-Fonseca (2006). Abundance of the largest subunit of RNA polymerase II in the nucleus is regulated by nucleo-cytoplasmic shuttling. Exp Cell Res 312(13): 2557-67.

Darnell, J. C., K. B. Jensen, P. Jin, V. Brown, S. T. Warren and R. B. Darnell (2001). Fragile $X$ mental retardation protein targets $G$ quartet mRNAs important for neuronal function. Cell 107(4): 489-99.

Darnell, J. C., O. Mostovetsky and R. B. Darnell (2005). FMRP RNA targets: identification and validation. Genes Brain Behav 4(6): 341-9.

Darnell, R. B. (1996). Onconeural antigens and the paraneoplastic neurologic disorders: at the intersection of cancer, immunity, and the brain. Proc Natl Acad Sci U S A 93(10): 4529-36.

Davidovic, L., X. H. Jaglin, A. M. Lepagnol-Bestel, S. Tremblay, M. Simonneau, B. Bardoni and E. W. Khandjian (2007). The fragile $X$ mental retardation protein is a molecular adaptor between the neurospecific KIF3C kinesin and dendritic RNA granules. Hum Mol Genet 16(24): 3047-58.

de Almeida, S. F. and M. Carmo-Fonseca (2008). The CTD role in cotranscriptional RNA processing and surveillance. FEBS Lett 582(14): 1971-6.

De Diego Otero, Y., L. A. Severijnen, G. van Cappellen, M. Schrier, B. Oostra and R. Willemsen (2002). Transport of fragile $X$ mental retardation protein via granules in neurites of PC12 cells. Mol Cell Biol 22(23): 8332-41.

de Moor, C. H., H. Meijer and S. Lissenden (2005). Mechanisms of translational control by the 3' UTR in development and differentiation. Semin Cell Dev Biol 16(1): 4958.

Denman, R. B. and Y. J. Sung (2002). Species-specific and isoform-specific RNA binding of human and mouse fragile $X$ mental retardation proteins. Biochem Biophys Res Commun 292(4): 1063-9.

Denoeud, F., P. Kapranov, C. Ucla, A. Frankish, R. Castelo, J. Drenkow, J. Lagarde, T. Alioto, C. Manzano, J. Chrast, et al. (2007). Prominent use of distal 5' transcription start sites and discovery of a large number of additional exons in ENCODE regions. Genome Res 17(6): 746-59.

DeNoto, F. M., D. D. Moore and H. M. Goodman (1981). Human growth hormone DNA sequence and mRNA structure: possible alternative splicing. Nucleic Acids Res 9(15): 3719-30.

Desai, N. S., T. M. Casimiro, S. M. Gruber and P. W. Vanderklish (2006). Early postnatal plasticity in neocortex of Fmr1 knockout mice. J Neurophysiol 96(4): 
1734-45.

Di Prospero, N. A. and K. H. Fischbeck (2005). Therapeutics development for triplet repeat expansion diseases. Nat Rev Genet 6(10): 756-65.

Didiot, M. C., Z. Tian, C. Schaeffer, M. Subramanian, J. L. Mandel and H. Moine (2008). The G-quartet containing FMRP binding site in FMR1 mRNA is a potent exonic splicing enhancer. Nucleic Acids Res.

Ding, X. Z., I. T. Paulsen, A. K. Bhattacharjee, M. P. Nikolich, G. Myers and D. L. Hoover (2006). A high efficiency cloning and expression system for proteomic analysis. Proteomics 6(14): 4038-46.

Doel, M. T., M. Houghton, E. A. Cook and N. H. Carey (1977). The presence of ovalbumin mRNA coding sequences in multiple restriction fragments of chicken DNA. Nucleic Acids Res 4(11): 3701-13.

Dolzhanskaya, N., G. Merz and R. B. Denman (2006). Alternative splicing modulates protein arginine methyltransferase-dependent methylation of fragile $\mathrm{X}$ syndrome mental retardation protein. Biochemistry 45(34): 10385-93.

Dredge, B. K. and R. B. Darnell (2003). Nova regulates GABA(A) receptor gamma2 alternative splicing via a distal downstream UCAU-rich intronic splicing enhancer. Mol Cell Biol 23(13): 4687-700.

Dunham, I. (2000). The gene guessing game. Yeast 17(3): 218-24.

Dunn, A. R. and J. A. Hassell (1977). A novel method to map transcripts: evidence for homology between an adenovirus mRNA and discrete multiple regions of the viral genome. Cell 12(1): 23-36.

Early, P., J. Rogers, M. Davis, K. Calame, M. Bond, R. Wall and L. Hood (1980). Two mRNAs can be produced from a single immunoglobulin mu gene by alternative RNA processing pathways. Cell 20(2): 313-9.

Eberhart, D. E., H. E. Malter, Y. Feng and S. T. Warren (1996). The fragile X mental retardation protein is a ribonucleoprotein containing both nuclear localization and nuclear export signals. Hum Mol Genet 5(8): 1083-91.

Eichler, E. E., S. Richards, R. A. Gibbs and D. L. Nelson (1993). Fine structure of the human FMR1 gene. Hum Mol Genet 2(8): 1147-53.

Enger, M. D. and R. A. Walters (1970). Isolation of low molecular weight, methylated ribonucleic acids from $10 \mathrm{~S}$ to $30 \mathrm{~S}$ particles of Chinese hamster cell fractions. Biochemistry 9(18): 3551-62.

Ewing, B. and P. Green (2000). Analysis of expressed sequence tags indicates 35,000 human genes. Nat Genet 25(2): 232-4.

Eyras, E., M. Caccamo, V. Curwen and M. Clamp (2004). ESTGenes: alternative splicing from ESTs in Ensembl. Genome Res 14(5): 976-87.

Fairbrother, W. G., R. F. Yeh, P. A. Sharp and C. B. Burge (2002). Predictive identification of exonic splicing enhancers in human genes. Science 297(5583): 1007-13.

Farrer, T., A. B. Roller, W. J. Kent and A. M. Zahler (2002). Analysis of the role of Caenorhabditis elegans GC-AG introns in regulated splicing. Nucleic Acids Res 30(15): 3360-7.

Feng, Y., C. A. Gutekunst, D. E. Eberhart, H. Yi, S. T. Warren and S. M. Hersch (1997). Fragile $X$ mental retardation protein: nucleocytoplasmic shuttling and association with somatodendritic ribosomes. J Neurosci 17(5): 1539-47.

Ferreira, E. N., P. A. Galante, D. M. Carraro and S. J. de Souza (2007). Alternative splicing: a bioinformatics perspective. Mol Biosyst 3(7): 473-7.

Field, D., N. Morrison, J. Selengut and P. Sterk (2006). Meeting report: eGenomics: Cataloguing our Complete Genome Collection II. Omics 10(2): 100-4.

Fields, S. (2001). Proteomics. Proteomics in genomeland. Science 291(5507): 1221-4.

Forch, P., O. Puig, N. Kedersha, C. Martinez, S. Granneman, B. Seraphin, P. Anderson and J. Valcarcel (2000). The apoptosis-promoting factor TIA-1 is a regulator of alternative pre-mRNA splicing. Mol Cell 6(5): 1089-98.

Frank, A. C., H. Amiri and S. G. Andersson (2002). Genome deterioration: loss of 
repeated sequences and accumulation of junk DNA. Genetica 115(1): 1-12.

Frazier, M. E., G. M. Johnson, D. G. Thomassen, C. E. Oliver and A. Patrinos (2003). Realizing the potential of the genome revolution: the genomes to life program. Science 300(5617): 290-3.

Frendewey, D. and W. Keller (1985). Stepwise assembly of a pre-mRNA splicing complex requires U-snRNPs and specific intron sequences. Cell 42(1): 355-67.

Fridell, R. A., R. E. Benson, J. Hua, H. P. Bogerd and B. R. Cullen (1996). A nuclear role for the Fragile $X$ mental retardation protein. Embo J 15(19): 5408-14.

$\mathrm{Fu}, \mathrm{X}$. D. and T. Maniatis (1992). Isolation of a complementary DNA that encodes the mammalian splicing factor SC35. Science 256(5056): 535-8.

Fu, Y. H., D. P. Kuhl, A. Pizzuti, M. Pieretti, J. S. Sutcliffe, S. Richards, A. J. Verkerk, J. J. Holden, R. G. Fenwick, Jr., S. T. Warren, et al. (1991). Variation of the CGG repeat at the fragile $X$ site results in genetic instability: resolution of the Sherman paradox. Cell 67(6): 1047-58.

Furdon, P. J. and R. Kole (1988). The length of the downstream exon and the substitution of specific sequences affect pre-mRNA splicing in vitro. Mol Cell Biol 8(2): 860-6.

Furey, T. S. (2006). Comparison of human (and other) genome browsers. Hum Genomics 2(4): 266-70.

Gabriel, S. B., S. F. Schaffner, H. Nguyen, J. M. Moore, J. Roy, B. Blumenstiel, J. Higgins, M. DeFelice, A. Lochner, M. Faggart, et al. (2002). The structure of haplotype blocks in the human genome. Science 296(5576): 2225-9.

Gabus, C., R. Mazroui, S. Tremblay, E. W. Khandjian and J. L. Darlix (2004). The fragile $X$ mental retardation protein has nucleic acid chaperone properties. Nucleic Acids Res 32(7): 2129-37.

Gabut, M., S. Chaudhry and B. J. Blencowe (2008). SnapShot: The splicing regulatory machinery. Cell 133(1): 192 e1.

Galas, D. J. (2001). Sequence interpretation. Making sense of the sequence. Science 291(5507): 1257-60.

Galiana-Arnoux, D., F. Del Gatto-Konczak, M. C. Gesnel and R. Breathnach (2005). Intronic UGG repeats coordinate splicing of CD44 alternative exons v8 and v9. Biochem Biophys Res Commun 336(2): 667-73.

Galperin, M. Y. (2006). The Molecular Biology Database Collection: 2006 update. Nucleic Acids Res 34(Database issue): D3-5.

Garriga, G. and A. M. Lambowitz (1986). Protein-dependent splicing of a group I intron in ribonucleoprotein particles and soluble fractions. Cell 46(5): 669-80.

Gawande, B., M. D. Robida, A. Rahn and R. Singh (2006). Drosophila Sex-lethal protein mediates polyadenylation switching in the female germline. Embo $\mathrm{J}$ 25(6): 1263-72.

Ge, H., P. Zuo and J. L. Manley (1991). Primary structure of the human splicing factor ASF reveals similarities with Drosophila regulators. Cell 66(2): 373-82.

Geslain, R. and L. Ribas de Pouplana (2004). Regulation of RNA function by aminoacylation and editing? Trends Genet 20(12): 604-10.

Gheldof, N., T. M. Tabuchi and J. Dekker (2006). The active FMR1 promoter is associated with a large domain of altered chromatin conformation with embedded local histone modifications. Proc Natl Acad Sci U S A 103(33): 12463-8.

Gibbs, R. A., G. M. Weinstock, M. L. Metzker, D. M. Muzny, E. J. Sodergren, S. Scherer, G. Scott, D. Steffen, K. C. Worley, P. E. Burch, et al. (2004). Genome sequence of the Brown Norway rat yields insights into mammalian evolution. Nature 428(6982): 493-521.

Gilbert, W. (1978). Why genes in pieces? Nature 271(5645): 501.

Glover, T. W., M. F. Arlt, A. M. Casper and S. G. Durkin (2005). Mechanisms of common fragile site instability. Hum Mol Genet 14 Spec No. 2: R197-205.

Goldenberg, C. J. (1984). In vitro-synthesized adenovirus 2 messenger RNA 
precursors are accurately spliced by nuclear extracts. Proc Natl Acad Sci U S A 81(15): 4707-11.

Goren, A., O. Ram, M. Amit, H. Keren, G. Lev-Maor, I. Vig, T. Pupko and G. Ast (2006). Comparative analysis identifies exonic splicing regulatory sequences-The complex definition of enhancers and silencers. Mol Cell 22(6): 769-81.

Grabowski, P. J. (2000). Genetic evidence for a Nova regulator of alternative splicing in the brain. Neuron 25(2): 254-6.

Grabowski, P. J. and D. L. Black (2001). Alternative RNA splicing in the nervous system. Prog Neurobiol 65(3): 289-308.

Grabowski, P. J., R. A. Padgett and P. A. Sharp (1984). Messenger RNA splicing in vitro: an excised intervening sequence and a potential intermediate. Cell 37(2): 415-27.

Grabowski, P. J., S. R. Seiler and P. A. Sharp (1985). A multicomponent complex is involved in the splicing of messenger RNA precursors. Cell 42(1): 345-53.

Graveley, B. R. (2001). Alternative splicing: increasing diversity in the proteomic world. Trends Genet 17(2): 100-7.

Graveley, B. R., K. J. Hertel and T. Maniatis (2001). The role of U2AF35 and U2AF65 in enhancer-dependent splicing. Rna 7(6): 806-18.

Gray, A. C., J. Raingo and D. Lipscombe (2007). Neuronal calcium channels: splicing for optimal performance. Cell Calcium 42(4-5): 409-17.

Greco, C. M., R. F. Berman, R. M. Martin, F. Tassone, P. H. Schwartz, A. Chang, B. D. Trapp, C. Iwahashi, J. Brunberg, J. Grigsby, et al. (2006). Neuropathology of fragile X-associated tremor/ataxia syndrome (FXTAS). Brain 129(Pt 1): 243-55.

Green, M. R., T. Maniatis and D. A. Melton (1983). Human beta-globin pre-mRNA synthesized in vitro is accurately spliced in Xenopus oocyte nuclei. Cell 32(3): 681-94.

Greenough, W. T., A. Y. Klintsova, S. A. Irwin, R. Galvez, K. E. Bates and I. J. Weiler (2001). Synaptic regulation of protein synthesis and the fragile $X$ protein. Proc Natl Acad Sci U S A 98(13): 7101-6.

Grossman, A. W., G. M. Aldridge, I. J. Weiler and W. T. Greenough (2006). Local protein synthesis and spine morphogenesis: Fragile $X$ syndrome and beyond. J Neurosci 26(27): 7151-5.

Guthrie, C. and B. Patterson (1988). Spliceosomal snRNAs. Annu Rev Genet 22: 387419.

Haddad, L. A., M. J. Aguiar, S. S. Costa, R. C. Mingroni-Netto, A. M. Vianna-Morgante and S. D. Pena (1999). Fully mutated and gray-zone FRAXA alleles in Brazilian mentally retarded boys. Am J Med Genet 84(3): 198-201.

Hagerman, P. J. and R. J. Hagerman (2004). Fragile X-associated tremor/ataxia syndrome (FXTAS). Ment Retard Dev Disabil Res Rev 10(1): 25-30.

Hagerman, R. J. (1992). Annotation: fragile X syndrome: advances and controversy. J Child Psychol Psychiatry 33(7): 1127-39.

Hagerman, R. J. and P. J. Hagerman (2002). The fragile X premutation: into the phenotypic fold. Curr Opin Genet Dev 12(3): 278-83.

Hagerman, R. J., M. Leehey, W. Heinrichs, F. Tassone, R. Wilson, J. Hills, J. Grigsby, B. Gage and P. J. Hagerman (2001). Intention tremor, parkinsonism, and generalized brain atrophy in male carriers of fragile X. Neurology 57(1): 127-30.

Hall-Pogar, T., S. Liang, L. K. Hague and C. S. Lutz (2007). Specific trans-acting proteins interact with auxiliary RNA polyadenylation elements in the COX-2 3'UTR. Rna 13(7): 1103-15.

Hamacher, M., R. Apweiler, G. Arnold, A. Becker, M. Bluggel, O. Carrette, C. Colvis, M. J. Dunn, T. Frohlich, M. Fountoulakis, et al. (2006). HUPO Brain Proteome Project: summary of the pilot phase and introduction of a comprehensive data reprocessing strategy. Proteomics 6(18): 4890-8.

Hamacher, M., C. Stephan, M. Bluggel, D. Chamrad, G. Korting, L. Martens, M. Muller, H. Hermjakob, D. Parkinson, A. Dowsey, et al. (2006). The HUPO Brain 
Proteome Project jamboree: centralised summary of the pilot studies.

Proteomics 6(6): 1719-21.

Han, X. D., B. R. Powell, J. L. Phalin and F. F. Chehab (2006). Mosaicism for a full mutation, premutation, and deletion of the CGG repeats results in 22\% FMRP and elevated FMR1 mRNA levels in a high-functioning fragile $X$ male. Am J Med Genet A 140(13): 1463-71.

Handa, V., T. Saha and K. Usdin (2003). The fragile X syndrome repeats form RNA hairpins that do not activate the interferon-inducible protein kinase, PKR, but are cut by Dicer. Nucleic Acids Res 31(21): 6243-8.

Hanke, J., D. Brett, I. Zastrow, A. Aydin, S. Delbruck, G. Lehmann, F. Luft, J. Reich and P. Bork (1999). Alternative splicing of human genes: more the rule than the exception? Trends Genet 15(10): 389-90.

Hansen, R. S., S. M. Gartler, C. R. Scott, S. H. Chen and C. D. Laird (1992). Methylation analysis of CGG sites in the $\mathrm{CpG}$ island of the human FMR1 gene. Hum Mol Genet 1(8): 571-8.

Harris, K. M., F. E. Jensen and B. Tsao (1992). Three-dimensional structure of dendritic spines and synapses in rat hippocampus (CA1) at postnatal day 15 and adult ages: implications for the maturation of synaptic physiology and longterm potentiation. J Neurosci 12(7): 2685-705.

Harrison, P. M., A. Kumar, N. Lang, M. Snyder and M. Gerstein (2002). A question of size: the eukaryotic proteome and the problems in defining it. Nucleic Acids Res 30(5): 1083-90.

Hayashizaki, Y. and M. Kanamori (2004). Dynamic transcriptome of mice. Trends Biotechnol 22(4): 161-7.

Haynes, C. and L. M. lakoucheva (2006). Serine/arginine-rich splicing factors belong to a class of intrinsically disordered proteins. Nucleic Acids Res 34(1): 305-12.

Heitz, D., F. Rousseau, D. Devys, S. Saccone, H. Abderrahim, D. Le Paslier, D. Cohen, A. Vincent, D. Toniolo, G. Della Valle, et al. (1991). Isolation of sequences that span the fragile $X$ and identification of a fragile $X$-related $\mathrm{CpG}$ island. Science 251(4998): 1236-9.

Hermjakob, H. (2006). The HUPO proteomics standards initiative--overcoming the fragmentation of proteomics data. Proteomics 6 Suppl 2: 34-8.

Hernandez, N. and W. Keller (1983). Splicing of in vitro synthesized messenger RNA precursors in HeLa cell extracts. Cell 35(1): 89-99.

Hessl, D., F. Tassone, D. Z. Loesch, E. Berry-Kravis, M. A. Leehey, L. W. Gane, I. Barbato, C. Rice, E. Gould, D. A. Hall, et al. (2005). Abnormal elevation of FMR1 mRNA is associated with psychological symptoms in individuals with the fragile X premutation. Am J Med Genet B Neuropsychiatr Genet 139B(1): 11521.

Hinds, H. L., C. T. Ashley, J. S. Sutcliffe, D. L. Nelson, S. T. Warren, D. E. Housman and M. Schalling (1993). Tissue specific expression of FMR-1 provides evidence for a functional role in fragile X syndrome. Nat Genet 3(1): 36-43.

Hinterberger, M., I. Pettersson and J. A. Steitz (1983). Isolation of small nuclear ribonucleoproteins containing U1, U2, U4, U5, and U6 RNAs. J Biol Chem 258(4): 2604-13.

Hodge, M. R. and M. G. Cumsky (1989). Splicing of a yeast intron containing an unusual 5' junction sequence. Mol Cell Biol 9(6): 2765-70.

Hodnett, J. L. and H. Busch (1968). Isolation and characterization of uridylic acid-rich 7 $S$ ribonucleic acid of rat liver nuclei. J Biol Chem 243(24): 6334-42.

Holste, D. and U. Ohler (2008). Strategies for identifying RNA splicing regulatory motifs and predicting alternative splicing events. PLoS Comput Biol 4(1): e21.

Horowitz, D. S., E. J. Lee, S. A. Mabon and T. Misteli (2002). A cyclophilin functions in pre-mRNA splicing. Embo J 21(3): 470-80.

Howard, E. F. (1978). Small nuclear RNA molecules in nuclear ribonucleoprotein complexes from mouse erythroleukemia cells. Biochemistry 17(16): 3228-36. 
Hu, L., Y. Chen, S. Evers and Y. Shen (2005). Expression of fragile X mental retardation-1 gene with nuclear export signal mutation changes the expression profiling of mouse cerebella immortal neuronal cell. Proteomics 5(15): 3979-90.

Huang, T., L. Y. Li, Y. Shen, X. B. Qin, Z. L. Pang and G. Y. Wu (1996). Alternative splicing of the FMR1 gene in human fetal brain neurons. Am J Med Genet 64(2): 252-5.

Hubbard, T., D. Barker, E. Birney, G. Cameron, Y. Chen, L. Clark, T. Cox, J. Cuff, V. Curwen, T. Down, et al. (2002). The Ensembl genome database project. Nucleic Acids Res 30(1): 38-41.

Hubbard, T. J., B. L. Aken, K. Beal, B. Ballester, M. Caccamo, Y. Chen, L. Clarke, G. Coates, F. Cunningham, T. Cutts, et al. (2007). Ensembl 2007. Nucleic Acids Res 35(Database issue): D610-7.

Huber, K. M., S. M. Gallagher, S. T. Warren and M. F. Bear (2002). Altered synaptic plasticity in a mouse model of fragile $X$ mental retardation. Proc Natl Acad Sci U S A 99(11): 7746-50.

Huot, M. E., R. Mazroui, P. Leclerc and E. W. Khandjian (2001). Developmental expression of the fragile X-related 1 proteins in mouse testis: association with microtubule elements. Hum Mol Genet 10(24): 2803-11.

IHGSC (2004). Finishing the euchromatic sequence of the human genome. Nature 431(7011): 931-45.

Ishizuka, A., M. C. Siomi and H. Siomi (2002). A Drosophila fragile X protein interacts with components of RNAi and ribosomal proteins. Genes Dev 16(19): 2497508.

Iwahashi, C. K., D. H. Yasui, H. J. An, C. M. Greco, F. Tassone, K. Nannen, B. Babineau, C. B. Lebrilla, R. J. Hagerman and P. J. Hagerman (2006). Protein composition of the intranuclear inclusions of FXTAS. Brain 129(Pt 1): 256-71.

Jasny, B. R. (2003). Building on the DNA Revolution. Science 300(5617): 277.

Jeffreys, A. J. and R. A. Flavell (1977). The rabbit beta-globin gene contains a large large insert in the coding sequence. Cell 12(4): 1097-108.

Jensen, K. B., B. K. Dredge, G. Stefani, R. Zhong, R. J. Buckanovich, H. J. Okano, Y. Y. Yang and R. B. Darnell (2000). Nova-1 regulates neuron-specific alternative splicing and is essential for neuronal viability. Neuron 25(2): 359-71.

Jin, P., R. S. Alisch and S. T. Warren (2004). RNA and microRNAs in fragile X mental retardation. Nat Cell Biol 6(11): 1048-53.

Jin, P., R. Duan, A. Qurashi, Y. Qin, D. Tian, T. C. Rosser, H. Liu, Y. Feng and S. T. Warren (2007). Pur alpha binds to rCGG repeats and modulates repeatmediated neurodegeneration in a Drosophila model of fragile $X$ tremor/ataxia syndrome. Neuron 55(4): 556-64.

Jin, P. and S. T. Warren (2000). Understanding the molecular basis of fragile $X$ syndrome. Hum Mol Genet 9(6): 901-8.

Johnson, J. M., J. Castle, P. Garrett-Engele, Z. Kan, P. M. Loerch, C. D. Armour, R. Santos, E. E. Schadt, R. Stoughton and D. D. Shoemaker (2003). Genomewide survey of human alternative pre-mRNA splicing with exon junction microarrays. Science 302(5653): 2141-4.

Jontes, J. D. and S. J. Smith (2000). Filopodia, spines, and the generation of synaptic diversity. Neuron 27(1): 11-4.

Kanapin, A., R. Apweiler, M. Biswas, W. Fleischmann, Y. Karavidopoulou, P. Kersey, E. V. Kriventseva, V. Mittard, N. Mulder, T. Oinn, et al. (2002). Interactive InterPro-based comparisons of proteins in whole genomes. Bioinformatics 18(2): 374-5.

Kanz, C., P. Aldebert, N. Althorpe, W. Baker, A. Baldwin, K. Bates, P. Browne, A. van den Broek, M. Castro, G. Cochrane, et al. (2005). The EMBL Nucleotide Sequence Database. Nucleic Acids Res 33(Database issue): D29-33.

Katayama, S., M. Kanamori and Y. Hayashizaki (2004). Integrated analysis of the genome and the transcriptome by FANTOM. Brief Bioinform 5(3): 249-58. 
Kaufmann, W. E. and A. L. Reiss (1999). Molecular and cellular genetics of fragile X syndrome. Am J Med Genet 88(1): 11-24.

Keeling, K. M., J. Salas-Marco, L. Z. Osherovich and D. M. Bedwell (2006). Tpa1p is part of an mRNP complex that influences translation termination, mRNA deadenylation, and mRNA turnover in Saccharomyces cerevisiae. Mol Cell Biol 26(14): 5237-48.

Kerrien, S., Y. Alam-Faruque, B. Aranda, I. Bancarz, A. Bridge, C. Derow, E. Dimmer, M. Feuermann, A. Friedrichsen, R. Huntley, et al. (2007). IntAct--open source resource for molecular interaction data. Nucleic Acids Res 35(Database issue): D561-5.

Kersey, P., L. Bower, L. Morris, A. Horne, R. Petryszak, C. Kanz, A. Kanapin, U. Das, K. Michoud, I. Phan, et al. (2005). Integr8 and Genome Reviews: integrated views of complete genomes and proteomes. Nucleic Acids Res 33(Database issue): D297-302.

Kersey, P., H. Hermjakob and R. Apweiler (2000). VARSPLIC: alternatively-spliced protein sequences derived from SWISS-PROT and TrEMBL. Bioinformatics 16(11): 1048-9.

Khalil, A. M., M. A. Faghihi, F. Modarresi, S. P. Brothers and C. Wahlestedt (2008). A novel RNA transcript with antiapoptotic function is silenced in fragile $X$ syndrome. PLoS ONE 3(1): e1486.

Khandjian, E. W. (1999). Biology of the fragile X mental retardation protein, an RNAbinding protein. Biochem Cell Biol 77(4): 331-42.

Khandjian, E. W., F. Corbin, S. Woerly and F. Rousseau (1996). The fragile X mental retardation protein is associated with ribosomes. Nat Genet 12(1): 91-3.

Khandjian, E. W., A. Fortin, A. Thibodeau, S. Tremblay, F. Cote, D. Devys, J. L. Mandel and F. Rousseau (1995). A heterogeneous set of FMR1 proteins is widely distributed in mouse tissues and is modulated in cell culture. Hum Mol Genet 4(5): 783-9.

Khorasanizadeh, S. (2004). The nucleosome: from genomic organization to genomic regulation. Cell 116(2): 259-72.

Kim, E., A. Magen and G. Ast (2007). Different levels of alternative splicing among eukaryotes. Nucleic Acids Res 35(1): 125-31.

Kim, H., R. Klein, J. Majewski and J. Ott (2004). Estimating rates of alternative splicing in mammals and invertebrates. Nat Genet 36(9): 915-6; author reply 916-7.

Kim, S. H. and R. J. Lin (1993). Pre-mRNA splicing within an assembled yeast spliceosome requires an RNA-dependent ATPase and ATP hydrolysis. Proc Natl Acad Sci U S A 90(3): 888-92.

Kinlaw, C. S., S. K. Dusing-Swartz and S. M. Berget (1982). Human U1 and U2 small nuclear ribonucleoproteins contain common and unique polypeptides. Mol Cell Biol 2(10): 1159-66.

Kinlaw, C. S., B. L. Robberson and S. M. Berget (1983). Fractionation and characterization of human small nuclear ribonucleoproteins containing $\mathrm{U} 1$ and U2 RNAs. J Biol Chem 258(11): 7181-9.

Kirkpatrick, L. L., K. A. Mcllwain and D. L. Nelson (2001). Comparative genomic sequence analysis of the FXR gene family: FMR1, FXR1, and FXR2. Genomics 78(3): 169-77.

Kitamura-Abe, S., H. Itoh, T. Washio, A. Tsutsumi and M. Tomita (2004). Characterization of the splice sites in GT-AG and GC-AG introns in higher eukaryotes using full-length cDNAs. J Bioinform Comput Biol 2(2): 309-31.

Koekkoek, S. K., K. Yamaguchi, B. A. Milojkovic, B. R. Dortland, T. J. Ruigrok, R. Maex, W. De Graaf, A. E. Smit, F. VanderWerf, C. E. Bakker, et al. (2005). Deletion of FMR1 in Purkinje cells enhances parallel fiber LTD, enlarges spines, and attenuates cerebellar eyelid conditioning in Fragile $X$ syndrome. Neuron 47(3): 339-52.

Konarska, M. M., P. J. Grabowski, R. A. Padgett and P. A. Sharp (1985). 
Characterization of the branch site in lariat RNAs produced by splicing of mRNA precursors. Nature 313(6003): 552-7.

Konarska, M. M., R. A. Padgett and P. A. Sharp (1985). Trans splicing of mRNA precursors in vitro. Cell 42(1): 165-71.

Konarska, M. M. and P. A. Sharp (1987). Interactions between small nuclear ribonucleoprotein particles in formation of spliceosomes. Cell 49(6): 763-74.

Kornblihtt, A. R. (2005). Promoter usage and alternative splicing. Curr Opin Cell Biol 17(3): $262-8$.

Krainer, A. R. and T. Maniatis (1985). Multiple factors including the small nuclear ribonucleoproteins $\mathrm{U} 1$ and $\mathrm{U} 2$ are necessary for pre-mRNA splicing in vitro. Cell 42(3): 725-36.

Krainer, A. R., T. Maniatis, B. Ruskin and M. R. Green (1984). Normal and mutant human beta-globin pre-mRNAs are faithfully and efficiently spliced in vitro. Cell 36(4): 993-1005.

Kramer, A. and U. Utans (1991). Three protein factors (SF1, SF3 and U2AF) function in pre-splicing complex formation in addition to snRNPs. Embo J 10(6): 1503-9.

Krawczak, M., J. Reiss and D. N. Cooper (1992). The mutational spectrum of single base-pair substitutions in mRNA splice junctions of human genes: causes and consequences. Hum Genet 90(1-2): 41-54.

Kremer, E. J., M. Pritchard, M. Lynch, S. Yu, K. Holman, E. Baker, S. T. Warren, D. Schlessinger, G. R. Sutherland and R. I. Richards (1991). Mapping of DNA instability at the fragile $X$ to a trinucleotide repeat sequence $p(C C G) n$. Science 252(5013): 1711-4.

Kremer, E. J., S. Yu, M. Pritchard, R. Nagaraja, D. Heitz, M. Lynch, E. Baker, V. J. Hyland, R. D. Little, M. Wada, et al. (1991). Isolation of a human DNA sequence which spans the fragile X. Am J Hum Genet 49(3): 656-61.

Kriventseva, E. V., I. Koch, R. Apweiler, M. Vingron, P. Bork, M. S. Gelfand and S. Sunyaev (2003). Increase of functional diversity by alternative splicing. Trends Genet 19(3): 124-8.

Kulikova, T., R. Akhtar, P. Aldebert, N. Althorpe, M. Andersson, A. Baldwin, K. Bates, S. Bhattacharyya, L. Bower, P. Browne, et al. (2007). EMBL Nucleotide Sequence Database in 2006. Nucleic Acids Res 35(Database issue): D16-20.

Kulikova, T., P. Aldebert, N. Althorpe, W. Baker, K. Bates, P. Browne, A. van den Broek, G. Cochrane, K. Duggan, R. Eberhardt, et al. (2004). The EMBL Nucleotide Sequence Database. Nucleic Acids Res 32(Database issue): D2730.

Ladd, P. D., L. E. Smith, N. A. Rabaia, J. M. Moore, S. A. Georges, R. S. Hansen, R. J. Hagerman, F. Tassone, S. J. Tapscott and G. N. Filippova (2007). An antisense transcript spanning the CGG repeat region of FMR1 is upregulated in premutation carriers but silenced in full mutation individuals. Hum Mol Genet 16(24): 3174-87.

Laggerbauer, B., D. Ostareck, E. M. Keidel, A. Ostareck-Lederer and U. Fischer (2001). Evidence that fragile $X$ mental retardation protein is a negative regulator of translation. Hum Mol Genet 10(4): 329-38.

Lander, E. S., L. M. Linton, B. Birren, C. Nusbaum, M. C. Zody, J. Baldwin, K. Devon, K. Dewar, M. Doyle, W. FitzHugh, et al. (2001). Initial sequencing and analysis of the human genome. Nature 409(6822): 860-921.

Lareau, L. F., R. E. Green, R. S. Bhatnagar and S. E. Brenner (2004). The evolving roles of alternative splicing. Curr Opin Struct Biol 14(3): 273-82.

Larson, J., R. E. Jessen, D. Kim, A. K. Fine and J. du Hoffmann (2005). Agedependent and selective impairment of long-term potentiation in the anterior piriform cortex of mice lacking the fragile $\mathrm{X}$ mental retardation protein. $\mathrm{J}$ Neurosci 25(41): 9460-9.

Lawn, R. M., E. F. Fritsch, R. C. Parker, G. Blake and T. Maniatis (1978). The isolation and characterization of linked delta- and beta-globin genes from a cloned library 
of human DNA. Cell 15(4): 1157-74.

Le Texier, V., J. J. Riethoven, V. Kumanduri, C. Gopalakrishnan, F. Lopez, D. Gautheret and T. A. Thanaraj (2006). AltTrans: transcript pattern variants annotated for both alternative splicing and alternative polyadenylation. BMC Bioinformatics 7: 169.

Lee, C. J. and K. Irizarry (2003). Alternative splicing in the nervous system: an emerging source of diversity and regulation. Biol Psychiatry 54(8): 771-6.

Lee, V., E. Camon, E. Dimmer, D. Barrell and R. Apweiler (2005). Who tangos with GOA?-Use of Gene Ontology Annotation (GOA) for biological interpretation of 'omics' data and for validation of automatic annotation tools. In Silico Biol 5(1): 5-8.

Lejeune, F. and L. E. Maquat (2005). Mechanistic links between nonsense-mediated mRNA decay and pre-mRNA splicing in mammalian cells. Curr Opin Cell Biol 17(3): 309-15.

Lerner, M. R., J. A. Boyle, S. M. Mount, S. L. Wolin and J. A. Steitz (1980). Are snRNPs involved in splicing? Nature 283(5743): 220-4.

Lerner, M. R. and J. A. Steitz (1979). Antibodies to small nuclear RNAs complexed with proteins are produced by patients with systemic lupus erythematosus. Proc Natl Acad Sci U S A 76(11): 5495-9.

Li, J., M. R. Pelletier, J. L. Perez Velazquez and P. L. Carlen (2002). Reduced cortical synaptic plasticity and GluR1 expression associated with fragile $X$ mental retardation protein deficiency. Mol Cell Neurosci 19(2): 138-51.

Li, Q., J. A. Lee and D. L. Black (2007). Neuronal regulation of alternative pre-mRNA splicing. Nat Rev Neurosci 8(11): 819-31.

Li, Z., Y. Zhang, L. Ku, K. D. Wilkinson, S. T. Warren and Y. Feng (2001). The fragile X mental retardation protein inhibits translation via interacting with mRNA. Nucleic Acids Res 29(11): 2276-83.

Lim, J. H., A. B. Booker and J. R. Fallon (2005). Regulating fragile X gene transcription in the brain and beyond. J Cell Physiol 205(2): 170-5.

Lin, C. L., S. Leu, M. C. Lu and P. Ouyang (2004). Over-expression of SR-cyclophilin, an interaction partner of nuclear pinin, releases SR family splicing factors from nuclear speckles. Biochem Biophys Res Commun 321(3): 638-47.

Lin, H., W. Zhu, J. C. Silva, X. Gu and C. R. Buell (2006). Intron gain and loss in segmentally duplicated genes in rice. Genome Biol 7(5): R41.

Lin, J. C. and W. Y. Tarn (2005). Exon selection in alpha-tropomyosin mRNA is regulated by the antagonistic action of RBM4 and PTB. Mol Cell Biol 25(22): 10111-21.

Lin, S. L., D. Chang, D. Y. Wu and S. Y. Ying (2003). A novel RNA splicing-mediated gene silencing mechanism potential for genome evolution. Biochem Biophys Res Commun 310(3): 754-60.

Lin, S. L., D. Chang and S. Y. Ying (2005). Asymmetry of intronic pre-miRNA structures in functional RISC assembly. Gene 356: 32-8.

Lin, S. L., S. J. Chang and S. Y. Ying (2006). First in vivo evidence of microRNAinduced fragile $X$ mental retardation syndrome. Mol Psychiatry 11(7): 616-7.

Ling, S. C., P. S. Fahrner, W. T. Greenough and V. I. Gelfand (2004). Transport of Drosophila fragile $X$ mental retardation protein-containing ribonucleoprotein granules by kinesin-1 and cytoplasmic dynein. Proc Natl Acad Sci U S A 101(50): 17428-33.

Lipscombe, D. (2005). Neuronal proteins custom designed by alternative splicing. Curr Opin Neurobiol 15(3): 358-63.

Lonberg, N. and W. Gilbert (1985). Intron/exon structure of the chicken pyruvate kinase gene. Cell 40(1): 81-90.

Lorkovic, Z. J., S. Lopato, M. Pexa, R. Lehner and A. Barta (2004). Interactions of Arabidopsis RS domain containing cyclophilins with SR proteins and U1 and U11 small nuclear ribonucleoprotein-specific proteins suggest their involvement 
in pre-mRNA Splicing. J Biol Chem 279(32): 33890-8.

Lubs, H. A. (1969). A marker X chromosome. Am J Hum Genet 21(3): 231-44.

Makalowski, W. (2001). The human genome structure and organization. Acta Biochim Pol 48(3): 587-98.

Maniatis, T. and R. Reed (1987). The role of small nuclear ribonucleoprotein particles in pre-mRNA splicing. Nature 325(6106): 673-8.

Maniatis, T. and B. Tasic (2002). Alternative pre-mRNA splicing and proteome expansion in metazoans. Nature 418(6894): 236-43.

Marzluff, W. F. (2007). U2 snRNP: not just for poly(A) mRNAs. Mol Cell 28(3): 353-4.

Matlin, A. J., F. Clark and C. W. Smith (2005). Understanding alternative splicing: towards a cellular code. Nat Rev Mol Cell Biol 6(5): 386-98.

Maurer-Stroh, S., N. J. Dickens, L. Hughes-Davies, T. Kouzarides, F. Eisenhaber and C. P. Ponting (2003). The Tudor domain 'Royal Family': Tudor, plant Agenet, Chromo, PWWP and MBT domains. Trends Biochem Sci 28(2): 69-74.

Mayeda, A. and A. R. Krainer (1992). Regulation of alternative pre-mRNA splicing by hnRNP A1 and splicing factor SF2. Cell 68(2): 365-75.

Mayeda, A., A. M. Zahler, A. R. Krainer and M. B. Roth (1992). Two members of a conserved family of nuclear phosphoproteins are involved in pre-mRNA splicing. Proc Natl Acad Sci U S A 89(4): 1301-4.

Mazroui, R., M. E. Huot, S. Tremblay, C. Filion, Y. Labelle and E. W. Khandjian (2002). Trapping of messenger RNA by Fragile $X$ Mental Retardation protein into cytoplasmic granules induces translation repression. Hum Mol Genet 11(24): 3007-17.

Meng, F., O. Zolova, N. A. Kokorina, A. Dobretsova and P. A. Wight (2005). Characterization of an intronic enhancer that regulates myelin proteolipid protein (Plp) gene expression in oligodendrocytes. J Neurosci Res 82(3): 34656.

Merendino, L., S. Guth, D. Bilbao, C. Martinez and J. Valcarcel (1999). Inhibition of msl-2 splicing by Sex-lethal reveals interaction between U2AF35 and the 3' splice site AG. Nature 402(6763): 838-41.

Meshorer, E. and T. Misteli (2005). Splicing misplaced. Cell 122(3): 317-8.

Mironov, A. A., J. W. Fickett and M. S. Gelfand (1999). Frequent alternative splicing of human genes. Genome Res 9(12): 1288-93.

Mischak, H. (2007). Clinical proteomics: A need to define the field and to begin to set adequate standards. Proteomics Clin. Appl. 1: 148-156.

Modrek, B. and C. Lee (2002). A genomic view of alternative splicing. Nat Genet 30(1): 13-9.

Modrek, B., A. Resch, C. Grasso and C. Lee (2001). Genome-wide detection of alternative splicing in expressed sequences of human genes. Nucleic Acids Res 29(13): 2850-9.

Moore, M. J. (2005). From birth to death: the complex lives of eukaryotic mRNAs. Science 309(5740): 1514-8.

Morgan, B. A., W. A. Johnson and J. Hirsh (1986). Regulated splicing produces different forms of dopa decarboxylase in the central nervous system and hypoderm of Drosophila melanogaster. Embo J 5(12): 3335-42.

Moroy, T. and F. Heyd (2007). The impact of alternative splicing in vivo: mouse models show the way. Rna 13(8): 1155-71.

Mortillaro, M. J. and R. Berezney (1998). Matrin CYP, an SR-rich cyclophilin that associates with the nuclear matrix and splicing factors. J Biol Chem 273(14): 8183-92.

Mueller, M., L. Martens and R. Apweiler (2007). Annotating the human proteome: beyond establishing a parts list. Biochim Biophys Acta 1774(2): 175-91.

Muramatsu, M., J. L. Hodnett and H. Busch (1966). Base composition of fractions of nuclear and nucleolar ribonucleic acid obtained by sedimentation and chromatography. J Biol Chem 241(7): 1544-50. 
Murray, V. and R. Holliday (1979). Mechanism for RNA splicing of gene transcripts. FEBS Lett 106(1): 5-7.

Nakamura, T., A. W. Prestayko and H. Busch (1968). Studies on nucleolar 4 to $6 \mathrm{~S}$ ribonucleic acid of Novikoff hepatoma cells. J Biol Chem 243(7): 1368-75.

Naumann, F., R. Remus, B. Schmitz and W. Doerfler (2004). Gene structure and expression of the 5'-(CGG)(n)-3'-binding protein (CGGBP1). Genomics 83(1): 106-18.

Newman, A. (1987). Specific accessory sequences in Saccharomyces cerevisiae introns control assembly of pre-mRNAs into spliceosomes. Embo J 6(12): 38339.

Nimchinsky, E. A., A. M. Oberlander and K. Svoboda (2001). Abnormal development of dendritic spines in FMR1 knock-out mice. J Neurosci 21(14): 5139-46.

Oberle, I., F. Rousseau, D. Heitz, C. Kretz, D. Devys, A. Hanauer, J. Boue, M. F. Bertheas and J. L. Mandel (1991). Instability of a 550-base pair DNA segment and abnormal methylation in fragile $X$ syndrome. Science 252(5010): 1097-102.

O'Donovan, C., R. Apweiler and A. Bairoch (2001). The human proteomics initiative (HPI). Trends Biotechnol 19(5): 178-81.

Ohashi, S., K. Koike, A. Omori, S. Ichinose, S. Ohara, S. Kobayashi, T. A. Sato and K. Anzai (2002). Identification of mRNA/protein (mRNP) complexes containing Puralpha, mStaufen, fragile $X$ protein, and myosin Va and their association with rough endoplasmic reticulum equipped with a kinesin motor. J Biol Chem 277(40): 37804-10.

Ohshima, Y., M. Itoh, N. Okada and T. Miyata (1981). Novel models for RNA splicing that involve a small nuclear RNA. Proc Natl Acad Sci U S A 78(7): 4471-4.

Oostra, B. A. (2002). Functions of the fragile X protein. Trends Mol Med 8(3): 102-3.

Oostra, B. A. and R. Willemsen (2003). A fragile balance: FMR1 expression levels. Hum Mol Genet 12 Spec No 2: R249-57.

Orchard, S., R. Apweiler, R. Barkovich, D. Field, J. S. Garavelli, D. Horn, A. Jones, P. Jones, R. Julian, R. McNally, et al. (2006). Proteomics and Beyond: a report on the 3rd Annual Spring Workshop of the HUPO-PSI 21-23 April 2006, San Francisco, CA, USA. Proteomics 6(16): 4439-43.

Orchard, S., H. Hermjakob, C. Taylor, R. Aebersold and R. Apweiler (2005). Human Proteome Organisation Proteomics Standards Initiative. Pre-Congress Initiative. Proteomics 5(18): 4651-2.

Osborne, C. S., L. Chakalova, K. E. Brown, D. Carter, A. Horton, E. Debrand, B. Goyenechea, J. A. Mitchell, S. Lopes, W. Reik, et al. (2004). Active genes dynamically colocalize to shared sites of ongoing transcription. Nat Genet 36(10): 1065-71.

Padgett, R. A., P. J. Grabowski, M. M. Konarska, S. Seiler and P. A. Sharp (1986). Splicing of messenger RNA precursors. Annu Rev Biochem 55: 1119-50.

Padgett, R. A., S. F. Hardy and P. A. Sharp (1983). Splicing of adenovirus RNA in a cell-free transcription system. Proc Natl Acad Sci U S A 80(17): 5230-4.

Padgett, R. A., M. M. Konarska, P. J. Grabowski, S. F. Hardy and P. A. Sharp (1984). Lariat RNA's as intermediates and products in the splicing of messenger RNA precursors. Science 225(4665): 898-903.

Padgett, R. A., S. M. Mount, J. A. Steitz and P. A. Sharp (1983). Splicing of messenger RNA precursors is inhibited by antisera to small nuclear ribonucleoprotein. Cell 35(1): 101-7.

Pandit, S., D. Wang and X. D. Fu (2008). Functional integration of transcriptional and RNA processing machineries. Curr Opin Cell Biol 20(3): 260-5.

Parker, R., P. G. Siliciano and C. Guthrie (1987). Recognition of the TACTAAC box during mRNA splicing in yeast involves base pairing to the U2-like snRNA. Cell 49(2): 229-39.

Pattyn, F., P. Robbrecht, A. De Paepe, F. Speleman and J. Vandesompele (2006). RTPrimerDB: the real-time PCR primer and probe database, major update 
2006. Nucleic Acids Res 34(Database issue): D684-8.

Pattyn, F., F. Speleman, A. De Paepe and J. Vandesompele (2003). RTPrimerDB: the real-time PCR primer and probe database. Nucleic Acids Res 31(1): 122-3.

Pederson, T. and N. G. Davis (1980). Messenger RNA processing and nuclear structure: isolation of nuclear ribonucleoprotein particles containing beta-globin messenger RNA precursors. J Cell Biol 87(1): 47-54.

Pennisi, E. (2001). The human genome. Science 291(5507): 1177-80.

Pertea, M., X. Lin and S. L. Salzberg (2001). GeneSplicer: a new computational method for splice site prediction. Nucleic Acids Res 29(5): 1185-90.

Piccioni, F., V. Zappavigna and A. C. Verrotti (2005). Translational regulation during oogenesis and early development: the cap-poly(A) tail relationship. C R Biol 328(10-11): 863-81.

Poon, P. M., Q. L. Chen, N. Zhong, S. T. Lam, K. Y. Lai, C. K. Wong and C. P. Pang (2006). AGG interspersion analysis of the FMR1 CGG repeats in mental retardation of unspecific cause. Clin Biochem 39(3): 244-8.

Pospisil, H., A. Herrmann, R. H. Bortfeldt and J. G. Reich (2004). EASED: Extended Alternatively Spliced EST Database. Nucleic Acids Res 32(Database issue): D70-4.

Pozdnyakova, I. and L. Regan (2005). New insights into Fragile X syndrome. Relating genotype to phenotype at the molecular level. Febs J 272(3): 872-8.

Primerano, B., F. Tassone, R. J. Hagerman, P. Hagerman, F. Amaldi and C. Bagni (2002). Reduced FMR1 mRNA translation efficiency in fragile $X$ patients with premutations. Rna 8(12): 1482-8.

Proudfoot, N. (2000). Connecting transcription to messenger RNA processing. Trends Biochem Sci 25(6): 290-3.

Proudfoot, N. J., A. Furger and M. J. Dye (2002). Integrating mRNA processing with transcription. Cell 108(4): 501-12.

Quackenbush, J. (2001). The power of public access: the human genome project and the scientific process. Nat Genet 29(1): 4-6.

Raharjo, S. B., N. Emoto, K. Ikeda, R. Sato, M. Yokoyama and M. Matsuo (2001). Alternative splicing regulates the endoplasmic reticulum localization or secretion of soluble secreted endopeptidase. J Biol Chem 276(27): 25612-20.

Raj, N. B., T. S. Ro-Choi and H. Busch (1975). Nuclear ribonucleoprotein complexes containing U1 and U2 RNA. Biochemistry 14(20): 4380-5.

Ramos, A., D. Hollingworth, S. Adinolfi, M. Castets, G. Kelly, T. A. Frenkiel, B. Bardoni and $A$. Pastore (2006). The structure of the $\mathrm{N}$-terminal domain of the fragile $X$ mental retardation protein: a platform for protein-protein interaction. Structure 14(1): 21-31.

Reeve, S. P., L. Bassetto, G. K. Genova, Y. Kleyner, M. Leyssen, F. R. Jackson and B. A. Hassan (2005). The Drosophila fragile $X$ mental retardation protein controls actin dynamics by directly regulating profilin in the brain. Curr Biol 15(12): 115663.

Reis, E. M., R. Louro, H. I. Nakaya and S. Verjovski-Almeida (2005). As antisense RNA gets intronic. Omics 9(1): 2-12.

Richards, B. W., P. E. Sylvester and C. Brooker (1981). Fragile X-linked mental retardation: the Martin-Bell syndrome. J Ment Defic Res 25 Pt 4: 253-6.

Roberts, L. (2001). The human genome. Controversial from the start. Science 291(5507): 1182-8.

Rodriguez-Revenga, L., M. Mila, C. Rosenberg, A. Lamb and C. Lee (2007). Structural variation in the human genome: the impact of copy number variants on clinical diagnosis. Genet Med 9(9): 600-6.

Roest Crollius, H., O. Jaillon, A. Bernot, C. Dasilva, L. Bouneau, C. Fischer, C. Fizames, P. Wincker, P. Brottier, F. Quetier, et al. (2000). Estimate of human gene number provided by genome-wide analysis using Tetraodon nigroviridis DNA sequence. Nat Genet 25(2): 235-8. 
Rogers, J. and R. Wall (1980). A mechanism for RNA splicing. Proc Natl Acad Sci U S A 77(4): 1877-9.

Rubin, G. M., M. D. Yandell, J. R. Wortman, G. L. Gabor Miklos, C. R. Nelson, I. K. Hariharan, M. E. Fortini, P. W. Li, R. Apweiler, W. Fleischmann, et al. (2000). Comparative genomics of the eukaryotes. Science 287(5461): 2204-15.

Ruskin, B., A. R. Krainer, T. Maniatis and M. R. Green (1984). Excision of an intact intron as a novel lariat structure during pre-mRNA splicing in vitro. Cell 38(1): 317-31.

Ruskin, B., P. D. Zamore and M. R. Green (1988). A factor, U2AF, is required for U2 snRNP binding and splicing complex assembly. Cell 52(2): 207-19.

Ryan, K., K. G. Murthy, S. Kaneko and J. L. Manley (2002). Requirements of the RNA polymerase II C-terminal domain for reconstituting pre-mRNA 3' cleavage. Mol Cell Biol 22(6): 1684-92.

Sambrook, J. (1977). Adenovirus amazes at Cold Spring Harbor. Nature 268(5616): 101-4.

Schellenberg, M. J., D. B. Ritchie and A. M. MacMillan (2008). Pre-mRNA splicing: a complex picture in higher definition. Trends Biochem Sci 33(6): 243-6.

Schenkel, J., C. E. Sekeris, A. Alonso and E. K. Bautz (1988). RNA-binding properties of hnRNP proteins. Eur J Biochem 171(3): 565-9.

Scherer, L. J. and J. J. Rossi (2003). Approaches for the sequence-specific knockdown of mRNA. Nat Biotechnol 21(12): 1457-65.

Schrier, M., L. A. Severijnen, S. Reis, M. Rife, S. van't Padje, G. van Cappellen, B. A. Oostra and R. Willemsen (2004). Transport kinetics of FMRP containing the I304N mutation of severe fragile $X$ syndrome in neurites of living rat PC12 cells. Exp Neurol 189(2): 343-53.

Shah, T., E. de Villiers, V. Nene, B. Hass, E. Taracha, M. J. Gardner, C. Sansom, R. Pelle and R. Bishop (2006). Using the transcriptome to annotate the genome revisited: application of massively parallel signature sequencing (MPSS). Gene 366(1): 104-8.

Shapiro, L., J. Love and D. R. Colman (2007). Adhesion molecules in the nervous system: structural insights into function and diversity. Annu Rev Neurosci 30: 451-74.

Shapiro, M. B. and P. Senapathy (1987). RNA splice junctions of different classes of eukaryotes: sequence statistics and functional implications in gene expression. Nucleic Acids Res 15(17): 7155-74.

Sharma, S. and D. L. Black (2006). Maps, codes, and sequence elements: can we predict the protein output from an alternatively spliced locus? Neuron 52(4): 574-6.

Sharp, P. A. and C. B. Burge (1997). Classification of introns: U2-type or U12-type. Cell 91(7): 875-9.

Shen, H. and M. R. Green (2006). RS domains contact splicing signals and promote splicing by a common mechanism in yeast through humans. Genes Dev 20(13): 1755-65.

Shen, H. and M. R. Green (2007). RS domain-splicing signal interactions in splicing of U12-type and U2-type introns. Nat Struct Mol Biol 14(7): 597-603.

Shen, H., J. L. Kan and M. R. Green (2004). Arginine-serine-rich domains bound at splicing enhancers contact the branchpoint to promote prespliceosome assembly. Mol Cell 13(3): 367-76.

Sherman, S. L., P. A. Jacobs, N. E. Morton, U. Froster-Iskenius, P. N. HowardPeebles, K. B. Nielsen, M. W. Partington, G. R. Sutherland, G. Turner and M. Watson (1985). Further segregation analysis of the fragile $X$ syndrome with special reference to transmitting males. Hum Genet 69(4): 289-99.

Sheth, N., X. Roca, M. L. Hastings, T. Roeder, A. R. Krainer and R. Sachidanandam (2006). Comprehensive splice-site analysis using comparative genomics. Nucleic Acids Res 34(14): 3955-67. 
Sheth, U. and R. Parker (2006). Targeting of aberrant mRNAs to cytoplasmic processing bodies. Cell 125(6): 1095-109.

Singh, N. N., E. J. Androphy and R. N. Singh (2004). An extended inhibitory context causes skipping of exon 7 of SMN2 in spinal muscular atrophy. Biochem Biophys Res Commun 315(2): 381-8.

Siomi, H., A. Ishizuka and M. C. Siomi (2004). RNA interference: a new mechanism by which FMRP acts in the normal brain? What can Drosophila teach us? Ment Retard Dev Disabil Res Rev 10(1): 68-74.

Siomi, H., M. C. Siomi, R. L. Nussbaum and G. Dreyfuss (1993). The protein product of the fragile $X$ gene, FMR1, has characteristics of an RNA-binding protein. Cell 74(2): 291-8.

Siomi, M. C., Y. Zhang, H. Siomi and G. Dreyfuss (1996). Specific sequences in the fragile $X$ syndrome protein FMR1 and the FXR proteins mediate their binding to $60 S$ ribosomal subunits and the interactions among them. Mol Cell Biol 16(7): 3825-32.

Sittler, A., D. Devys, C. Weber and J. L. Mandel (1996). Alternative splicing of exon 14 determines nuclear or cytoplasmic localisation of fmr1 protein isoforms. Hum Mol Genet 5(1): 95-102.

Smaglik, P. (2000). Researchers take a gamble on the human genome. Nature 405(6784): 264.

Smith, C. W. (2005). Alternative splicing--when two's a crowd. Cell 123(1): 1-3.

Smith, P. J., C. Zhang, J. Wang, S. L. Chew, M. Q. Zhang and A. R. Krainer (2006). An increased specificity score matrix for the prediction of SF2/ASF-specific exonic splicing enhancers. Hum Mol Genet 15(16): 2490-508.

Soares, L. M., K. Zanier, C. Mackereth, M. Sattler and J. Valcarcel (2006). Intron removal requires proofreading of U2AF/3' splice site recognition by DEK. Science 312(5782): 1961-5.

Soeiro, R., H. C. Birnboim and J. E. Darnell (1966). Rapidly labeled HeLa cell nuclear RNA. II. Base composition and cellular localization of a heterogeneous RNA fraction. J Mol Biol 19(2): 362-72.

Sofola, O. A., P. Jin, Y. Qin, R. Duan, H. Liu, M. de Haro, D. L. Nelson and J. Botas (2007). RNA-binding proteins hnRNP A2/B1 and CUGBP1 suppress fragile $X$ CGG premutation repeat-induced neurodegeneration in a Drosophila model of FXTAS. Neuron 55(4): 565-71.

Sorek, R., R. Shamir and G. Ast (2004). How prevalent is functional alternative splicing in the human genome? Trends Genet 20(2): 68-71.

Southan, C. (2004). Has the yo-yo stopped? An assessment of human protein-coding gene number. Proteomics 4(6): 1712-26.

Spector, D. L., X. D. Fu and T. Maniatis (1991). Associations between distinct premRNA splicing components and the cell nucleus. Embo J 10(11): 3467-81.

Sri-Widada, J., J. P. Liautard, C. Brunel and P. Jeanteur (1983). Interaction of snRNAs with rapidly sedimenting nuclear sub-structures (hnRNPs) from HeLa cells. Nucleic Acids Res 11(19): 6631-46.

Stamm, S., S. Ben-Ari, I. Rafalska, Y. Tang, Z. Zhang, D. Toiber, T. A. Thanaraj and H. Soreq (2005). Function of alternative splicing. Gene 344: 1-20.

Stamm, S., J. J. Riethoven, V. Le Texier, C. Gopalakrishnan, V. Kumanduri, Y. Tang, N. L. Barbosa-Morais and T. A. Thanaraj (2006). ASD: a bioinformatics resource on alternative splicing. Nucleic Acids Res 34(Database issue): D4655.

Stetefeld, J. and M. A. Ruegg (2005). Structural and functional diversity generated by alternative mRNA splicing. Trends Biochem Sci 30(9): 515-21.

Stevenin, J., H. Gallinaro-Matringe, R. Gattoni and M. Jacob (1977). Complexity of the structure of particles containing heterogeneous nuclear RNA as demonstrated by ribonuclease treatment. Eur J Biochem 74(3): 589-602.

Stoesser, G., W. Baker, A. van den Broek, M. Garcia-Pastor, C. Kanz, T. Kulikova, R. 
Leinonen, Q. Lin, V. Lombard, R. Lopez, et al. (2003). The EMBL Nucleotide Sequence Database: major new developments. Nucleic Acids Res 31(1): 17-22.

Strair, R. K., S. H. Yap and D. A. Shafritz (1977). Use of molecular hybridization to purify and analyze albumin messenger RNA from rat liver. Proc Natl Acad Sci U S A 74(10): 4346-50.

Sun, Q., A. Mayeda, R. K. Hampson, A. R. Krainer and F. M. Rottman (1993). General splicing factor SF2/ASF promotes alternative splicing by binding to an exonic splicing enhancer. Genes Dev 7(12B): 2598-608.

Suzuki, H. (2006). Protein-protein interactions in the mammalian brain. J Physiol 575(Pt 2): 373-7.

Szabo, P., M. Purrello, M. Rocchi, N. Archidiacono, B. Alhadeff, G. Filippi, D. Toniolo, G. Martini, L. Luzzatto and M. Siniscalco (1984). Cytological mapping of the human glucose-6-phosphate dehydrogenase gene distal to the fragile- $X$ site suggests a high rate of meiotic recombination across this site. Proc Natl Acad Sci U S A 81(24): 7855-9.

Tamanini, F., C. Bontekoe, C. E. Bakker, L. van Unen, B. Anar, R. Willemsen, M. Yoshida, H. Galjaard, B. A. Oostra and A. T. Hoogeveen (1999). Different targets for the fragile $X$-related proteins revealed by their distinct nuclear localizations. Hum Mol Genet 8(5): 863-9.

Tanaka, K., A. Watakabe and Y. Shimura (1994). Polypurine sequences within a downstream exon function as a splicing enhancer. Mol Cell Biol 14(2): 1347-54.

Tange, T. O., C. K. Damgaard, S. Guth, J. Valcarcel and J. Kjems (2001). The hnRNP A1 protein regulates HIV-1 tat splicing via a novel intron silencer element. Embo J 20(20): 5748-58.

Tarn, W. Y. and J. A. Steitz (1997). Pre-mRNA splicing: the discovery of a new spliceosome doubles the challenge. Trends Biochem Sci 22(4): 132-7.

Tassone, F., A. Beilina, C. Carosi, S. Albertosi, C. Bagni, L. Li, K. Glover, D. Bentley and P. J. Hagerman (2007). Elevated FMR1 mRNA in premutation carriers is due to increased transcription. Rna 13(4): 555-62.

Tassone, F., R. J. Hagerman, A. K. Taylor, L. W. Gane, T. E. Godfrey and P. J. Hagerman (2000). Elevated levels of FMR1 mRNA in carrier males: a new mechanism of involvement in the fragile-X syndrome. Am J Hum Genet 66(1): 6-15.

Tazi, J., S. Durand and P. Jeanteur (2005). The spliceosome: a novel multi-faceted target for therapy. Trends Biochem Sci 30(8): 469-78.

Teferedegne, B., M. R. Green, Z. Guo and J. M. Boss (2006). Mechanism of action of a distal NF-kappaB-dependent enhancer. Mol Cell Biol 26(15): 5759-70.

Teigelkamp, S., T. Achsel, C. Mundt, S. F. Gothel, U. Cronshagen, W. S. Lane, M. Marahiel and R. Luhrmann (1998). The 20kD protein of human [U4/U6.U5] trisnRNPs is a novel cyclophilin that forms a complex with the U4/U6-specific 60kD and 90kD proteins. Rna 4(2): 127-41.

Terracciano, A., P. Chiurazzi and G. Neri (2005). Fragile X syndrome. Am J Med Genet C Semin Med Genet 137C(1): 32-7.

Thanaraj, T. A. (2000). Positional characterisation of false positives from computational prediction of human splice sites. Nucleic Acids Res 28(3): 744-54.

Thanaraj, T. A. and F. Clark (2001). Human GC-AG alternative intron isoforms with weak donor sites show enhanced consensus at acceptor exon positions. Nucleic Acids Res 29(12): 2581-93.

Thanaraj, T. A., F. Clark and J. Muilu (2003). Conservation of human alternative splice events in mouse. Nucleic Acids Res 31(10): 2544-52.

Thanaraj, T. A., A. Robinson, J. Muilu and J. J. Riethoven (2000). Paradigm shifts in the approaches for gene annotation. Brief Bioinform 1(4): 324-9.

Thanaraj, T. A. and A. J. Robinson (2000). Prediction of exact boundaries of exons. Brief Bioinform 1(4): 343-56.

Thanaraj, T. A. and S. Stamm (2003). Prediction and statistical analysis of alternatively 
spliced exons. Prog Mol Subcell Biol 31: 1-31.

Thanaraj, T. A., S. Stamm, F. Clark, J. J. Riethoven, V. Le Texier and J. Muilu (2004). ASD: the Alternative Splicing Database. Nucleic Acids Res 32(Database issue): D64-9.

Tijsterman, M. and R. H. Plasterk (2004). Dicers at RISC; the mechanism of RNAi. Cell 117(1): 1-3.

Tilghman, S. M., D. C. Tiemeier, J. G. Seidman, B. M. Peterlin, M. Sullivan, J. V. Maizel and $P$. Leder (1978). Intervening sequence of DNA identified in the structural portion of a mouse beta-globin gene. Proc Natl Acad Sci U S A 75(2): 725-9.

Till, S., E. Lejeune, R. Thermann, M. Bortfeld, M. Hothorn, D. Enderle, C. Heinrich, M. W. Hentze and A. G. Ladurner (2007). A conserved motif in Argonauteinteracting proteins mediates functional interactions through the Argonaute PIWI domain. Nat Struct Mol Biol 14(10): 897-903.

Tonegawa, S., A. M. Maxam, R. Tizard, O. Bernard and W. Gilbert (1978). Sequence of a mouse germ-line gene for a variable region of an immunoglobulin light chain. Proc Natl Acad Sci U S A 75(3): 1485-9.

Ule, J. and R. B. Darnell (2006). RNA binding proteins and the regulation of neuronal synaptic plasticity. Curr Opin Neurobiol 16(1): 102-10.

Ule, J., G. Stefani, A. Mele, M. Ruggiu, X. Wang, B. Taneri, T. Gaasterland, B. J. Blencowe and R. B. Darnell (2006). An RNA map predicting Nova-dependent splicing regulation. Nature 444(7119): 580-6.

Ule, J., A. Ule, J. Spencer, A. Williams, J. S. Hu, M. Cline, H. Wang, T. Clark, C. Fraser, M. Ruggiu, et al. (2005). Nova regulates brain-specific splicing to shape the synapse. Nat Genet 37(8): 844-52.

Ureta-Vidal, A., L. Ettwiller and E. Birney (2003). Comparative genomics: genome-wide analysis in metazoan eukaryotes. Nat Rev Genet 4(4): 251-62.

Valencia-Sanchez, M. A., J. Liu, G. J. Hannon and R. Parker (2006). Control of translation and mRNA degradation by miRNAs and siRNAs. Genes Dev 20(5): 515-24.

Valverde, R., I. Pozdnyakova, T. Kajander, J. Venkatraman and L. Regan (2007). Fragile $\mathrm{X}$ mental retardation syndrome: structure of the $\mathrm{KH} 1-\mathrm{KH} 2$ domains of fragile $X$ mental retardation protein. Structure 15(9): 1090-8.

van den Berg, J., A. van Ooyen, N. Mantei, A. Schambock, G. Grosveld, R. A. Flavell and C. Weissmann (1978). Comparison of cloned rabbit and mouse beta-globin genes showing strong evolutionary divergence of two homologous pairs of introns. Nature 276(5683): 37-44.

Van Esch, H. (2006). The Fragile X premutation: new insights and clinical consequences. Eur J Med Genet 49(1): 1-8.

Vanderklish, P. W. and G. M. Edelman (2005). Differential translation and fragile X syndrome. Genes Brain Behav 4(6): 360-84.

Vandesompele, J., K. De Preter, F. Pattyn, B. Poppe, N. Van Roy, A. De Paepe and F. Speleman (2002). Accurate normalization of real-time quantitative RT-PCR data by geometric averaging of multiple internal control genes. Genome Biol 3(7): RESEARCH0034.

Venkatesh, B., E. F. Kirkness, Y. H. Loh, A. L. Halpern, A. P. Lee, J. Johnson, N. Dandona, L. D. Viswanathan, A. Tay, J. C. Venter, et al. (2006). Ancient noncoding elements conserved in the human genome. Science 314(5807): 1892.

Venter, J. C., M. D. Adams, E. W. Myers, P. W. Li, R. J. Mural, G. G. Sutton, H. O. Smith, M. Yandell, C. A. Evans, R. A. Holt, et al. (2001). The sequence of the human genome. Science 291(5507): 1304-51.

Verheij, C., C. E. Bakker, E. de Graaff, J. Keulemans, R. Willemsen, A. J. Verkerk, H. Galjaard, A. J. Reuser, A. T. Hoogeveen and B. A. Oostra (1993). Characterization and localization of the FMR-1 gene product associated with fragile $X$ syndrome. Nature 363(6431): 722-4. 
Verheij, C., E. de Graaff, C. E. Bakker, R. Willemsen, P. J. Willems, N. Meijer, H. Galjaard, A. J. Reuser, B. A. Oostra and A. T. Hoogeveen (1995).

Characterization of FMR1 proteins isolated from different tissues. Hum Mol Genet 4(5): 895-901.

Verkerk, A. J., E. de Graaff, K. De Boulle, E. E. Eichler, D. S. Konecki, E. Reyniers, A. Manca, A. Poustka, P. J. Willems, D. L. Nelson, et al. (1993). Alternative splicing in the fragile X gene FMR1. Hum Mol Genet 2(8): 1348.

Verkerk, A. J., M. Pieretti, J. S. Sutcliffe, Y. H. Fu, D. P. Kuhl, A. Pizzuti, O. Reiner, S. Richards, M. F. Victoria, F. P. Zhang, et al. (1991). Identification of a gene (FMR-1) containing a CGG repeat coincident with a breakpoint cluster region exhibiting length variation in fragile $X$ syndrome. Cell 65(5): 905-14.

Vianna-Morgante, A. M. (1999). Twinning and premature ovarian failure in premutation fragile X carriers. Am J Med Genet 83(4): 326.

Vianna-Morgante, A. M. and S. S. Costa (2000). Premature ovarian failure is associated with maternally and paternally inherited premutation in Brazilian families with fragile X. Am J Hum Genet 67(1): 254-5; author reply 256-8.

Vianna-Morgante, A. M., S. S. Costa, A. S. Pares and I. T. Verreschi (1996). FRAXA premutation associated with premature ovarian failure. Am J Med Genet 64(2): 373-5.

Vogel, G. (2001). The human genome. Objection \#2: why sequence the junk? Science 291(5507): 1184.

Wang, H., J. B. Dictenberg, L. Ku, W. Li, G. J. Bassell and Y. Feng (2008). Dynamic Association of the Fragile $X$ Mental Retardation Protein as a Messenger Ribonucleoprotein between Microtubules and Polyribosomes. Mol Biol Cell 19(1): 105-14.

Wang, J., P. J. Smith, A. R. Krainer and M. Q. Zhang (2005). Distribution of SR protein exonic splicing enhancer motifs in human protein-coding genes. Nucleic Acids Res 33(16): 5053-62.

Wang, M. and A. Marin (2006). Characterization and prediction of alternative splice sites. Gene 366(2): 219-27.

Wang, Y. C., M. L. Lin, S. J. Lin, Y. C. Li and S. Y. Li (1997). Novel point mutation within intron 10 of FMR-1 gene causing fragile $X$ syndrome. Hum Mutat 10(5): 393-9.

Wang, Z., M. E. Rolish, G. Yeo, V. Tung, M. Mawson and C. B. Burge (2004). Systematic identification and analysis of exonic splicing silencers. Cell 119(6): 831-45.

Wang, Z., X. Xiao, E. Van Nostrand and C. B. Burge (2006). General and specific functions of exonic splicing silencers in splicing control. Mol Cell 23(1): 61-70.

Weiler, I. J., S. A. Irwin, A. Y. Klintsova, C. M. Spencer, A. D. Brazelton, K. Miyashiro, T. A. Comery, B. Patel, J. Eberwine and W. T. Greenough (1997). Fragile X mental retardation protein is translated near synapses in response to neurotransmitter activation. Proc Natl Acad Sci U S A 94(10): 5395-400.

Weinberg, R. A., U. Loening, M. Willems and S. Penman (1967). Acrylamide gel electrophoresis of HeLa cell nucleolar RNA. Proc Natl Acad Sci U S A 58(3): 1088-95.

Weinberg, R. A. and S. Penman (1968). Small molecular weight monodisperse nuclear RNA. J Mol Biol 38(3): 289-304.

Weinstock, R., R. Sweet, M. Weiss, H. Cedar and R. Axel (1978). Intragenic DNA spacers interrupt the ovalbumin gene. Proc Natl Acad Sci U S A 75(3): 1299303.

Wen, F., F. Li, H. Xia, X. Lu, X. Zhang and Y. Li (2004). The impact of very short alternative splicing on protein structures and functions in the human genome. Trends Genet 20(5): 232-6.

Will, C. L. and R. Luhrmann (2005). Splicing of a rare class of introns by the U12dependent spliceosome. Biol Chem 386(8): 713-24. 
Williams, A. M. and S. A. Martinis (2006). Mutational unmasking of a tRNA-dependent pathway for preventing genetic code ambiguity. Proc Natl Acad Sci U S A 103(10): 3586-91.

Williamson, R. (1977). An approach to the understanding of messenger ribonucleic acid synthesis, processing and regulation in eukaryotes. Biochem Soc Symp(42): 99-102.

Willingham, A. T. and T. R. Gingeras (2006). TUF love for "junk" DNA. Cell 125(7): 1215-20.

Wilton, S. D. and S. Fletcher (2005). RNA splicing manipulation: strategies to modify gene expression for a variety of therapeutic outcomes. Curr Gene Ther 5(5): 467-83.

Wong, M. L. and J. F. Medrano (2005). Real-time PCR for mRNA quantitation. Biotechniques 39(1): 75-85.

Wu, S., C. M. Romfo, T. W. Nilsen and M. R. Green (1999). Functional recognition of the 3' splice site AG by the splicing factor U2AF35. Nature 402(6763): 832-5.

Xiao, S., S. Tjostheim, T. Sanelli, J. R. McLean, P. Horne, Y. Fan, J. Ravits, M. J. Strong and J. Robertson (2008). An aggregate-inducing peripherin isoform generated through intron retention is upregulated in amyotrophic lateral sclerosis and associated with disease pathology. J Neurosci 28(8): 1833-40.

Xing, Y. and C. Lee (2006). Alternative splicing and RNA selection pressure-evolutionary consequences for eukaryotic genomes. Nat Rev Genet 7(7): 499509.

Yamamori, T. (1992). Molecular mechanisms for generation of neural diversity and specificity: roles of polypeptide factors in development of postmitotic neurons. Neurosci Res 12(5): 545-82.

Yang, V. W., M. R. Lerner, J. A. Steitz and S. J. Flint (1981). A small nuclear ribonucleoprotein is required for splicing of adenoviral early RNA sequences. Proc Natl Acad Sci U S A 78(3): 1371-5.

Yeo, G., D. Holste, G. Kreiman and C. B. Burge (2004). Variation in alternative splicing across human tissues. Genome Biol 5(10): R74.

Yeo, G., S. Hoon, B. Venkatesh and C. B. Burge (2004). Variation in sequence and organization of splicing regulatory elements in vertebrate genes. Proc Natl Acad Sci U S A 101(44): 15700-5.

Yokoyama, S. (2003). Protein expression systems for structural genomics and proteomics. Curr Opin Chem Biol 7(1): 39-43.

Yu, S., M. Pritchard, E. Kremer, M. Lynch, J. Nancarrow, E. Baker, K. Holman, J. C. Mulley, S. T. Warren, D. Schlessinger, et al. (1991). Fragile X genotype characterized by an unstable region of DNA. Science 252(5010): 1179-81.

Zahler, A. M., W. S. Lane, J. A. Stolk and M. B. Roth (1992). SR proteins: a conserved family of pre-mRNA splicing factors. Genes Dev 6(5): 837-47.

Zalfa, F., M. Giorgi, B. Primerano, A. Moro, A. Di Penta, S. Reis, B. Oostra and C. Bagni (2003). The fragile $X$ syndrome protein FMRP associates with BC1 RNA and regulates the translation of specific mRNAs at synapses. Cell 112(3): 31727.

Zamore, P. D. and M. R. Green (1989). Identification, purification, and biochemical characterization of $\mathrm{U} 2$ small nuclear ribonucleoprotein auxiliary factor. Proc Natl Acad Sci U S A 86(23): 9243-7.

Zarnescu, D. C., G. Shan, S. T. Warren and P. Jin (2005). Come FLY with us: toward understanding fragile $X$ syndrome. Genes Brain Behav 4(6): 385-92.

Zhang, X. H. and L. A. Chasin (2004). Computational definition of sequence motifs governing constitutive exon splicing. Genes Dev 18(11): 1241-50.

Zhang, Y., J. P. O'Connor, M. C. Siomi, S. Srinivasan, A. Dutra, R. L. Nussbaum and G. Dreyfuss (1995). The fragile $X$ mental retardation syndrome protein interacts with novel homologs FXR1 and FXR2. Embo J 14(21): 5358-66.

Zhou, Z., L. J. Licklider, S. P. Gygi and R. Reed (2002). Comprehensive proteomic 
analysis of the human spliceosome. Nature 419(6903): 182-5.

Zipursky, S. L., W. M. Wojtowicz and D. Hattori (2006). Got diversity? Wiring the fly brain with Dscam. Trends Biochem Sci 31(10): 581-8.

Zorio, D. A. and T. Blumenthal (1999). Both subunits of U2AF recognize the 3' splice site in Caenorhabditis elegans. Nature 402(6763): 835-8.

Zorio, D. A. and T. Blumenthal (1999). U2AF35 is encoded by an essential gene clustered in an operon with RRM/cyclophilin in Caenorhabditis elegans. Rna 5(4): 487-94.

Zumwalt, M., A. Ludwig, P. J. Hagerman and T. Dieckmann (2007). Secondary structure and dynamics of the $r(C G G)$ repeat in the mRNA of the fragile $X$ mental retardation 1 (FMR1) gene. RNA Biol 4(2): 93-100.

Zuniga, A., J. Juan, M. Mila and A. Guerrero (2005). Expansion of an intermediate allele of the FMR1 gene in only two generations. Clin Genet 68(5): 471-3. 